Andrews University

Digital Commons @ Andrews University

1976

\title{
Dimensions of the Ideal Family as Perceived by Adolescents
}

Lily Hok-Neo Wong

Andrews University

Follow this and additional works at: https://digitalcommons.andrews.edu/dissertations

Part of the Family, Life Course, and Society Commons

\section{Recommended Citation}

Wong, Lily Hok-Neo, "Dimensions of the Ideal Family as Perceived by Adolescents" (1976). Dissertations. 1557.

https://digitalcommons.andrews.edu/dissertations/1557

https://dx.doi.org/10.32597/dissertations/1577

This Dissertation is brought to you for free and open access by the Graduate Research at Digital Commons @ Andrews University. It has been accepted for inclusion in Dissertations by an authorized administrator of Digital Commons@ Andrews University. For more information, please contact repository@andrews.edu. 


\section{Andrews \$university}

Seek Knowledge. Affirm Faith. Change the World.

Thank you for your interest in the

\section{Andrews University Digital Library of Dissertations and Theses.}

Please honor the copyright of this document by not duplicating or distributing additional copies in any form without the author's express written permission. Thanks for your cooperation. 


\section{INFORMATION TO USERS}

This material was produced from a microfilm copy of the original document. While the most advanced technological means to photograph and reproduce this document have been used, the quality is heavily dependent upon the quality of the original submitted.

The following explanation of techniques is provided to help you understand markings or patterns which may appear on this reproduction.

1. The sign or "target" for pages apparently lacking from the document photographed is "Missing Page(s)". If it was possible to obtain the missing page(s) or section, they are spliced into the film along with adjacent pages. This may have necessitated cutting thru an image and duplicating adjacent pages to insure you complete continuity.

2. When an image on the film is obliterated with a large round black mark, it is an indication that the photographer suspected that the copy may have moved during exposure and thus cause a blurred image. You will find a good image of the page in the adjacent frame.

3. When a map, drawing or chart, etc., was part of the material being photographed the photographer followed a definite method in "sectioning" the material. It is customary to begin photoing at the upper left hand corner of a large sheet and to continue photoing from left to right in equal sections with a small overlap. If necessary, sectioning is continued again - beginning below the first row and continuing on until complete.

4. The majority of users indicate that the textual content is of greatest valus. however, a somewhat higher quality reproduction could be made from "photographs" if essential to the understanding of the dissertation. Silver prints of "photographs" may be ordered at additional charge by writing the Order Department, giving the catalog number, title, author and specific pages you wish reproduced.

5. PLEASE NOTE: Some pages may have indistinct print. Filmed as received.

Xerox University Microfilms

300 North Zeeb Road

Ann Arbor, Mici.izan 48106 
$76 \cdot 30,342$

HOK-NEO, Lily Wong, 1944-

DIMENSIONS OF THE IDEAL FAMILY AS PERCEIVED BY ADOLESCENTS.

Andrews University, Ed.D., 1976

Education, psychology

Xerox University Microfilms, Ann Arbor, Michigan 48106

Reproduced with permission of the copyright owner. Further reproduction prohibited without permission. 
Andrews UnIversity

School of Graduate Studles

\title{
DIMENSIONS OF THE IDEAL EAMILY AS PERCEIVED BY ADOLESCENTS
}

\author{
A Dissertation \\ Presented in Partial Fulfillment \\ of the Requirements for the Degree \\ Doctor of Education
}

\author{
by \\ Lily Wong Hok-Neo \\ July 1976
}

Reproduced with permission of the copyright owner. Further reproduction prohibited without permission. 


\section{DIMENSIONS OF THE IDEAL FAMILY AS \\ PERCEIVED BY ADOLESCENTS}

A dissertation presented

in partial fulfillment of the requirements

for the degree

Doctor of Education

by

Lily Wong Hok-Neo

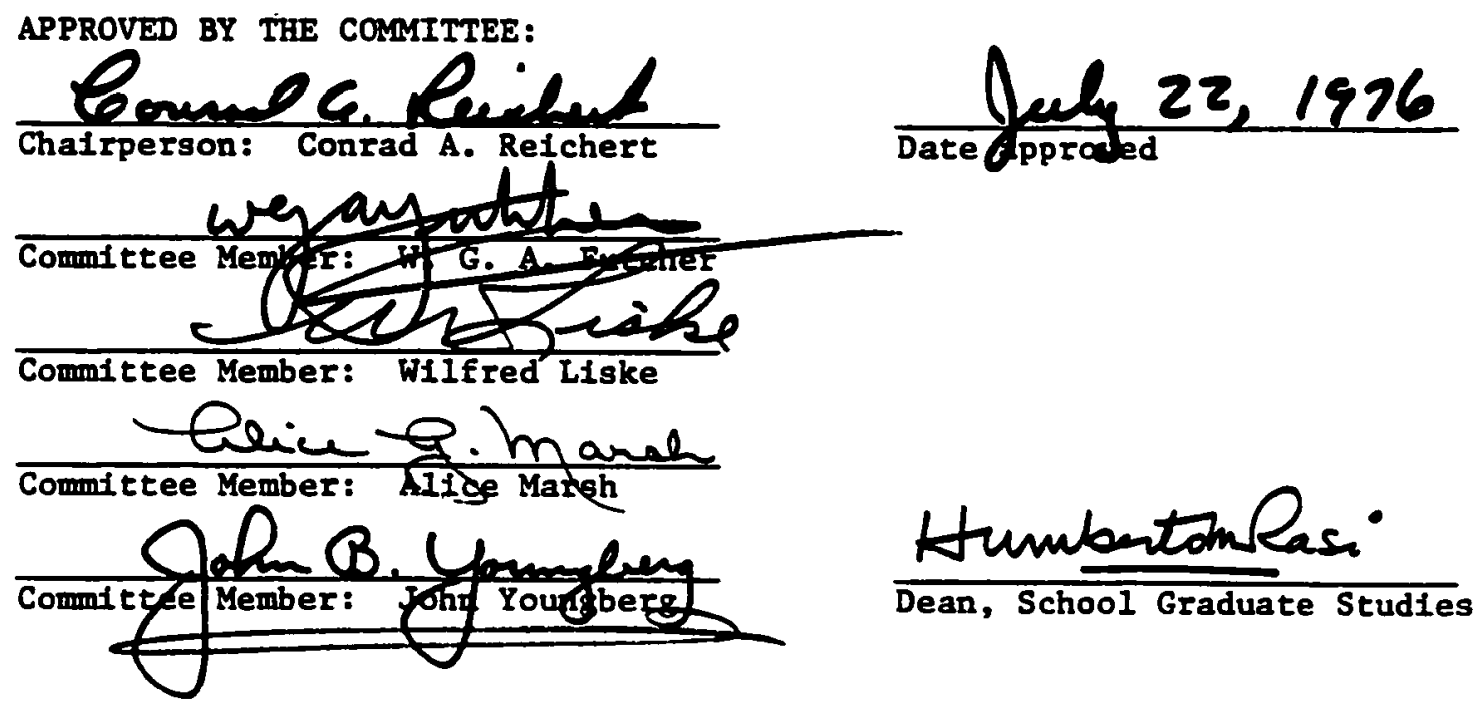

Reproduced with permission of the copyright owner. Further reproduction prohibited without permission. 


\section{ABSTRACT}

\section{DIMENSIONS OF THE IDEAL FAMILY AS \\ PERCEIVED BY ADOLESCENTS}

by

\section{Lily Wong Hok-Neo}

Chairperson: Conrad A. Relchert 


\title{
ABSTRACT OF GRADUATE STUDENT RESEARCB \\ Dissertation
}

Andrews University

Department of Education

\author{
TIt le: DIMENSIONS OF THE IDEAL FAMILY AS PERCEIVED BY ADOLESCENTS \\ Name of Researcher: Lily Wong Hok-Neo \\ Name and t1tle of faculty adviser: Conrad A. Reichert, Ph.D. \\ Date completed: July 1976
}

\section{Problem}

The purpose of this study was to Identify the types of family concept held by different groups of adolescents in thirteen selected high schools in Illinois, Indiana, and Michigan. Could the adolescents' concepts of the ideal family be described in terms of a number of factors? If there were basic factors, how would they compare with those previously identified by van der Veen in his study of disturbed adolescents? Were there differences in the Ideal family concept when the adolescents were compared according to grade in school, church membership, sex, race, residential location, and number of parents? With the answers to these questions, varfous helping organizations In the community can formulate realistic family life curricula as

\section{1}


well as lay the groundwork and foundation for strong famtlies in the future.

Method

This study employed the descriptive method involving factor analysis, the t-test of significance between means, one-way analysis of variance, multivariate analysis of variance, and discriminant analysis. Seven hypotheses were advanced for testing. A panel of experts helped determine the descriptors for the dimensions Ident1fled by factor analysis.

The data came from 123 randomly selected ninth and twelfth graders from seven Seventh-day Adventist academies and six public senior high schools. There were 66 males and 57 females. Eightyseven of the subjects were white and 35 were non-whites. Rural, urban, and suburban residential locations were represented in the study. The majority of the subjects lived with both parents. The Family Concept Test developed by van der Veen was used to measure the adolescents' vlewpolnts on different aspects of the ideal family. The responses were indicated by rating how much each of the 80 statements were like what they wanted their ideal family to be on a scale of 0 to 8 . The data were entered, processed, and analyzed.

\section{Findings}

Twelve independent but psychologically meaningful factors were identified after a varimax rotation. These were: (1) attachment, (2) emotional openness, (3) compatibility, (4) inadequacy, (5) individuality, (6) interdependence, (7) mutual support, (8) pseudo- 
confidence, (9) frustration, (10) communication, (11) autonomy, and (12) democracy.

The t-test for significance between means revealed diffarences between adolescents when they were compared according to church membership, and sex. The one-way analysis of variance showed that the urban adolescents differed from rural and urban adolescents, but the latter two groups did not differ significantly from each other. Grade in school, race, and parental number were not found to be significantly related to Ideal fantly concept.

The multivariate analysis of varlance using the twelve factor scores 1solated by factor analysis, revealed that the subjects differed in their ideal family concept when they were compared according to church membership, race, and residential location. Grade in school, sex, and parental number were not found to be significantly related to the factor centroids.

Discriminant analysis of factor scores revealed that the factors, emotional openness, compatibility, and individuality were most sensitive in discriminating between the various subgroups of students.

\section{Conclustons}

The study showed that it was possible to describe the adolescents' concept of the ideal family in terms of basic factors. The twelve factors identified were very different from those previously identified by van der Veen in his research on disturbed adolescents. Hence, normal adolescents perceived their ideal families differently from disturbed adolescents. 
of the six variables, church membership and sex are definite determinants of the development of the ideal family concept. Seventhday Adventist adolescents have a more positive family concept than non-Seventh-day Adventist adolescents, and girls have a more positive family concept than boys. Suburban adolescents have a more positive family concept than urban or rural adolescents. The whites viewed the ideal family differently from the non-whites. Grades in school and number of parents did not seem to have any significant effect on the ideal family concept of the adolescents. 
TABLE OF CONTENTS

ACKNOWLEDGEMENTS . . . . . . . . . . . . . . . xili

Chapter

I. INTRODUCTION . . . . . . . . . . . . . . . . . . 1

Statement of the Problen . . . . . . . . . . . . . 1

Purpose of the Study . . . . . . . . . . . . . . 2

Definition of Terms .................... 3

Importance of the Study ... . . . . . . . . . . . . 4

II. REVIEW OF RELATED LITERATURE . . . . . . . . . . . . 5

Introduction .................... 5

Family Theories and Frames of Reference... . . . . . 5

Basic Approaches ........ . . . . . . . 5

Structural-Functional Approach . . . . . . . . . 6

Interactional and Situational Approach . . . . . . 7

Developmental Approach ............... 8

Models of Familial Socialization . . . . . . . . 9

Development of Parent-Adolescent Relationships . . . . 11

Socialization and the Growth Process. . . . . . . . . 11

Adolescent Autonomy . . . . . . . . . . . . . 12

Adolescent Conflict . . . . . . . . . . . . . . 14

Influences on the Adolescent Perception of

the Family . . . . . . . . . . . . . . . . . 16

Development of the Family Concept . . . . . . . . . 18

Factors Influencing the Family Concept . . . . . . . 18

Summary of the Chapter . . . . . . . . . . . . . . 21

Tentative Conclusions . . . . . . . . . . . . 22

III. RESEARCH DESIGN AND METHODOLOGY . . . . . . . . . . . 24

Research Design . . . . . . . . . . . . 24

Independent Variables . . . . . . . . . . . . 24

Dependent Variables ................ . 24

Statement of Hypotheses .............. . 25

Instrumentation . . . . . . . . . . . . . . . 26

Van der Veen's Family Unit

Inventory (FUI) . . . . . . . . . . . . . 26

Development of the Instrument by van der Veen . . . . 27

Reliability and Validity . . . . . . . . . . . . . 29

Other Studies on the FUI . . . . . . . . . . . . 30

Field Procedures and Data-gathering . . . . . . . 31

Pilot Study . . . . . . . . . . . . . . . 31

ix 
Population and Sample... . . . . . . . . 32

Method of Approaching Principals . . . . . . . . 33

Administration of the FUI . . . . . . . . . . . . . 33

Data Recording, Processing, and Analysis . . . . . . . 35

Data Recording . . . . . . . . . . . . . . . . . 35

Data Entry .. . . . . . . . . . . . . . . . 35

Data Analysis . . . . . . . . . . . . . . 35

IV. PRESENTATION OF FINDINGS . . . . . . . . . . . 37

Dimensions of the Ideal Family Concept . . . . . . 37

Difference Between Subgroups . . . . . . . . . . 50

Differences In Ideal Family Concept According

to Group Means on Total Score . . . . . . . . . 50

Differences in Ideal Family Concept According

to Factors. . . . . . . . . . . . . . . 52

Factors that Discriminate Between Significant

Varlables . . . . . . . . . . . . . 53

Summary of Significant Discriminant Function

Analyses . . . . . . . . . . . . . . . 57

V. SUMMARY, CONCLUSIONS, AND IMPLICATIONS . . . . . . 60

Summary . . . . . . . . . . . . . . . . . 60

Conclusions . . . . . . . . . . . . . . . . 63

Discussions on Eindings . . . . . . . . . . . . 67

Implications . . . . . . . . . . . . . . . . . . 68

For the Seventh-day Adventist Church . . . . . . 69

For Educators and Psychologists . . . . . . . . . 69

For Further Theoretical Studies . . . . . . . 70

APPENDICES . . . . . . . . . . . . . . . . . 72

A. The Fanily Unit Inventory . . . . . . . . . . . 73

B. Family Concept Test--Positive and Negative Items . . . . 81

C. Total Scores of Subjects . . . . . . . . . . . . . . . . 84

D. An 80 X 80 Intercorrelation Matrix between Items . . . 89

E. An 80 X 12 Correlation Matrix Between Items

and Factors... . . . . . . . . . . . . . . . 98

F. An $123 \times 12$ Correlation Matrix for Facror Scores . . . . 101

G. Means of All Groups on All Factors . . . . . . . . . . 104

BIBLIOGRAPHY .................. . 107

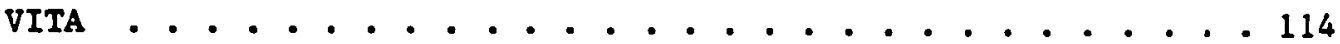


Table

Page

1. Characteristics of the Sample . . . . . . . . 34

2. Item Loadings on Factor I . . . . . . . . . . . . 39

3. Item Loadings on Factor II . . . . . . . . . . 40

4. Item Loadings on Factor III . . . . . . . . . . . . 41

5. Item Loadings on Factor IV .. . . . . . . . . . . 42

6. Item Loadings on Factor V. . . . . . . . . . . . 43

7. Item Loadings on Factor VI . . . . . . . . . . 43

8. Item Loadings on Factor VII . . . . . . . . . . . . . 44

9. Item Loadings on Factor VIII . . . . . . . . . . . . . 44

10. Item Loadings on Factor IX .. . . . . . . . . . 45

11. Item Loadings on Factor X . . . . . . . . . . . 46

12. Item Loadings on Factor XI . . . . . . . . . . 46

13. Item Loadings on Factor XII . . . . . . . . . . 47

14. Factors in the Concept of the Ideal Family as
Revealed by van der Veen and by this Study ..... 48

15. Comparison of Item Clusterings Between van der
Veen's and the Present Study ........... 49

16. Differences Between Groups with Variables
Using Tctal Scores ........... 50

17. Analysis of Variance of Differences in Ideal

Family Concepts Among Adolescents from

Rural, Urban, and Suburban Residential Locations. . 51

18. Differences between Groups based on Twelve

Factors as Analyzed by MANOVA . . . . . . . . . 52

$\mathbf{x 1}$ 
19. Group Means Used in Discriminant Analysis Between Church Membership ............ 54

20. Discriminant Function Analysis Between Seventh-day Adventist and Non-Seventh-day Adventist Adolescents................. 54

21. Group Means Used in Discriminant Analysis Between Race . . . . . . . . . . . . 56

22. Discriminant Function Analysis Between Whites and Non-Whites .............. 56

23. Group Means Used in Discriminant Analysis Among ResIdential Locations . . . . . . . . . . . . 57

24. Discriminant Function Analysis Among Residential Locatlons . . . . . . . . . . . . . 57

25. Summary of Significant Discriminant Function Coefficients . . . . . . . . . . . . 59

26. Factor Means on All Groups on All Factors . . . . . 104 


\section{ACKNOWLEDGEMENTS}

I am most grateful to the members of my doctoral comittee-Dr. Alice Marsh, Dr. John Youngberg, Dr. Wilfred Liske, and especlally Dr. Conrad Reichert, my chairperson, Eor patiently and carefully readIng and guiding the preparation of this dissertation.

Spectal thanks goes to Dr.W. G. A. Futcher, who spent countless hours working out computer programs (MUDISC and others), helping in the interpretation of the findings, editing the script, and providing much encouragement in the writing of this dissertation.

To Ruth Ann Plue and her assoclates at the Andrews University Computer Center I owe much for the efficlent services that made it possible to complete the analysis of the data in a very short time.

I am indebted to Dr. Ferdinand van der Veen for permisston to use the Family Unit Inventory.

Many thanks go to Rikl Hall for the typing of the first two drafts, to Serena Gui for coming all the way to help we with housekeeping duties so that I could concentrate on my writing, to the Far Eastern Division of Seventh-day Adventists and the Southeast Asia Union College in Singapore for financlal support, and to the Hewitt Research Center for logistical support.

To my son, Sydney, I am'grateful for the patience and unselfishness in bearing with me while working on this document. Above all, praise be to God who gave me the strength and wisdom to complete this task. 
CHAPTER I

INTRODUCTION

\section{Statement of the Problem}

The past few years have seen a growing awareness of the 1mportant role played by parents in children's psychological and social development. Rruger (1972), comparing contemporary family life in America with that of the past century, describes it as being less intimate, less organized, less concerned with passing on family precepts and standards. The family no longer serves as the active agent for the propagation of family life. More and more, it has become the responsibllity of the school to fulfill what were previously felt to be functions of the family.

This trend has serfous implications for adolescents who have a major interest in selecting mates and planning for future families on their own. According to Kruger (1972), in 1968 approximately one out of ten seventeen-year-old girls in the United States was a mother. In 1971 , nearly fifteen per cent of the estimated 210,000 school-age girls under seventeen years of age who gave birth were not having their first baby. Statistics in 1972 suggested that six out of ten of these mothers were married by the time their child was born, and that, married or not, the majority of these school-age mothers kept their children. 
School-age parents form a set of "high-risk" families that often result from an Inadequate understanding of and preparation for parenthood responsioilities. This is borne out by the fact that national divorce rates for those married in their teens are about three to four times higher than those of any other age group. This disintegration causes unhappiness and problems among the parents and children involved.

Since these are high school adolescents, the schools are presently attempting to set up family-life curricula. These curricula can be more meaningfully constructed if the curriculum planners understand the adolescents' perception of the famtly.

\section{Purpose of the Study}

The purpose of this study was to identify the ideal family concept of adolescents in select Midwest states, and to compare family concepts between sub-groups within the sample. Family concept for this sample is referred to as the cognitive-emotional "schema" (analogous to self-concept) consisting of a person's perception, feelings, attitudes, and experiences regarding the family unit.

Specifically, the following questions were investigated:

1. Can the adolescent's concept of the Ideal family be described in terms of a number of basic factors?

2. If there are basic factors, how do they compare with those Identified by van der Veen (1971) in his study of disturbed adolescents? 
3. Are there differences in the ideal family concept when the adolescents are compared according to
a. grade in school?
b. church membership?
c. sex?
d. race?
e. residential location?
f. parental number?

\section{Definition of Terms}

A family is a social unit consisting of married adults and their biological or adopted children that maintain a common residence and perform their economic and socialization functions together.

The family concept, analogous to the self-concept, is a cognitive-emotional "schema" consisting of a person's perception, feelings, attitudes, and expectations regarding the family unit (van der Veen, 1971, p. 1). It is the way an Individual perceives his family as a functioning unit.

Parental number. The term includes both parents which refers to a family situation in which both father and mother live together with the children, and one parent which refers to the family situation in which the children live with either the father or the mother.

Academies are senior high schools operated by the Seventhday Adventist Church. 
Church membership is used to categorize the subjects into two groups: (1) Seventh-day Adventists, and (2) non-Seventh-day Adventists, which include Catholics, Lutherans, Methodists, Presbyterlans, and others.

Residential location refers to the type of setting in which the adolescent subjects' homes were located when the study was conducted. Three categories-rural, urban, and suburban--are used.

A factor is a construct, a hypothetical entity, that is assumed to underlie tests, scales, items, and Indeed, measures of any kind (Kerlinger, 1973, p. 659).

\section{Importance of the Study}

A serles of studies on the family concept by other researchers has looked at influences of the family concept on variables such as family congruence, family satisfaction, family adjustment or effectiveness, and family compatibility. The importance of this study lies in its approach to 1dentifying factors underlying family concepts. While the study of van der Veen (1971) has pioneered the attempt to Identify factors underlying family concept, the study was undertaken with a spectfic sub-population. This study sought to identify factors in a more normal population. This study explored adolescent attitudes and expectations toward ideal family life. With this information, various helping organizations--especially schools--in the community can formulate realistic family life curricula to help lay the groundwork and foundation for strong families in the future. 
CHAPTER II

\section{REVIEW OF RELATED IITERATURE}

\section{Introduction}

The family has long been a subject of study of sociclogists, anthropologists, psychologists, home economists, and religious leaders. Yet not until the last two decades have sclentific, theory-bullding approaches been used.

The literature regarding the viewpoint that the adolescent's perception of the family is developed from family interaction and that it is subjected to changes under different environments is reviewed in this chapter. This review is divided into three areas:

1. Family theories and frames of reference

2. Development of parent-adolescent relationships

3. Influences or adolescents' perceptions of the family

\section{Family Theorles and Frames of Reference}

\section{Basic Approaches}

Like the theoreticians in most flelds, family scholars are increasingly attempting to organize their accumulated knowledge in the form of concepts, generalizations, and theories. Particularly since 1960, specialists in family studies have been consclous of the need to organize concepts, develop hypotheses and propositions, and to interrelate these propositions in a 
meaningful fashion in order to explain a particular aspect of family organization and behavior.

Christensen (1964) listed and discussed four different approaches in studying the family:

1. The institutional approach

2. The structural-functional approach

3. The interactional and situational approaches

4. The developmental approach

Jf the original four, only three have survived the test of time. Klein, Calvert, Garland and Polomoro (1969) surveyed family research and theory and concluded that only the interactional, structural-functional, and famlly developmental approaches have continued to generate fresh inquiry. These three frames of reference are summarized below.

\section{Structural-Functicnal Approach}

The structural-functional approach is a common conceptual framework in social sclence research. Summartzing this approach, Shultz (1971) outlined three basic postulates:

1. Every soclety should be viewed as a whole or system.

2. Every part of a given system is influenced by every other part, so that a change in one part is likely to bring about a change in every other part.

3. A system is In dynamic equilibrium so that change occurs within limits.

Murdock (1965) held that structure was definftely related to function and stated that the family, as a particular structure 
(with a system of positions and roles), universally performed the same functions. Pitts (1964) reviewed Murdock's work and designated the functions of the nuclear family as (1) maintaining its members in physical and mental health by economic cooperation and tension reduction, (2) reproduction of the species, and (3) training of children for community roles. Schultz (1972) further upheld these functions when he said that in every society the family was the institution that was "normatively entrusted with the responsibility of the reproduction and the basic soclalization of the children who are necessary to the perpetuation of that society" (p. 5).

\section{Interactional and Situational Approach}

This approach is known by some as the "role theory" or "symbolic interaction theory" (Stryker, 1959). The proponents of this approach present a set of explanations for the social and psychological processes of socialization and personality development.

Two divergent traditions, social behaviorfsm and symbolic Interactionism, have developed from role theory. Behaviorists see socialization as an interaction process. Roles develop out of the Interaction of persons as they mutually define the situation In which their interaction occurs.

Symbolic interactionism concentrates on roles as they develop from Individuals' attempts to communicate. Man's primary symbol system, language, is seen as a determining factor in his development. The views of Mead (1934) and Cooley (1964) are that 
we have a social as well as a personal component. The soclal component or the objectively perceivable "ME" is essentially a repertolze of behaviors developed in response to the expectations of others (especially significant others). For Mead, the perceiving "I" is almost an illusion. The self is so much determined by the particular social situation in which the individual finds himself, that the "I" is all but eliminated. We are a little more than the sum total of our situational selves.

Cooley's (1964) explanation of the "looking-glass self" states the extent to which we are interdependent beings. In this view the "self" is composed of three elements: (1) an estimation of alter's conception of ego, (2) an assessment of alter's evaluation of that conception, and (3) ego's self-assessment such as a feeling of competence or guilt. In Cooley's thought, the family is a primary group characterized by its small slze, face-to-face Interaction, persistence, intimacy, and the care and concern that its members have for one another.

\section{Developmental Approach}

The developmental approach, Inltiated by Duvall (1957) has been one of the oldest standard approaches. Hill and Rogers described the detalls of a framework in Christensen's (1964) Handbook of Marrlage and the Family. This approach has, as its chief focus, the analysis of changes in family roles over time. In carrying out such an analysis, attention is pald, primarily to three areas:

1. The structure of the soclety in which the family exists

2. The structure of the family per se 
3. The role dynamics of the family viewed primarily as a consequence of specific age, sex, and plurality compositions.

H111 and Hansen (1960) pointed out the fact that thls theory was not a unique approach but rather a joining-together of various parts of some of the previous theoretical efforts. It actually attempts to combine into one theory the societal-institutional, Interactional-assoclational, and individual-personality variables of the family phenomenon. This approach tries to direct its attention to the longitudinal career of the family system. It attempts to be microanalytic and to account for changes in patterns of interaction over the family life span.

\section{Models of Famillal Soclalization}

The internal process of family socialization has been defined in two ways. Cogswell (1969) referred to it as the role relationships of parents and offspring. Parsons (1955) claimed that the passing on of attitudes and perceptions of the family was the important function. In relation to these definitions two models of the socialization process were developed by Winch and Warimer.

The first model of the socialization process is the fusion of functional and learning theory focusing upon the problem of how It is that parents are able (or not able, as the case may be) to exert lasting Influence upon their children (Winch, 1972). Winch refers to it as the model of identification which attempts to relate 
structural-functional variables to the process of identification through the Intervening concepts of "reward" and "ego 1deal," or role models.

The second model, developed by Warimer (1970), promotes the process of soctal interaction as being very important to the emergence and formulation of roles. As a result of this process, soclal institutions and personality traits are developed.

The common element in both these models is the social role of the family. This is perceived as (1) a set of expectations of behavior and attitudes considered appropriate to the members of the family, and (2) the patterns of conduct organized in response to these expectations which are results of interaction.

Van der Veen (1971) feels that the family concept develops principally from interaction with the family over an extended period of time. Family concept (analogous to self-concept) is defined as the cognitive-emotional "schema" consisting of a person's perception, feelings, attitudes, and experiences regarding the family unit. The famlly concept exerts a potential and lasting influence on behavior. He further holds that this concept is subject to change and revision under a variety of conditions--including formal intervention.

Schultz (1972) classifies the family as an informal organization with roles rarely made explicit. Appropriate behavior for the roles of husband-father, wife-mother, and sibling-child are frequently learned by imitation and modified by the day-to-day interaction of family members. 
It is therefore not unreasonable to expect that many of the enduring attitudes that a person has are the result of the pattern of active Interaction he has experienced and percelved from within his family group. Differences between a person's attitudes and those of others should, therefore, reflect different family concepts. Specifically, in terms of adolescent development, changes in roles and perceptions that accompany increasing autonomy and extra-familial commitments go on to shape family concept. These changes can be correlated with changes in the perception of the actors in familial roles (Campbel1, 1969). Greater satisfaction in the family concept is also present when there is greater congruence between real and 1deal perceptions of the family (Holland, 1970; van der Veen, 1971).

\section{Development of Parent-Adolescent Relationships}

Socialization and the Growth Process

The process of acquiring a way of life is a very normal and natural consequence of prolonged exposure to family members In a more or less closed system of soctal interaction. The deep union and blological intimacies between mother and child set a firm foundation for a pattern of soclallzation, which, when reinforced by the sharing of experiences by family members, gives family life a very spectal character.

Children depend on their parents for food, protection, and emotional support. They identify with their parents and tend to imitate their behavior. Differences in opinions exist; but, during early childhood, the parents' rights to assume authority and to assert power are rarely challenged. 
As children grow older and take on their own identities, values, and perceptions, this pleasant assoclation of members of the family takes on different expressions and behavioral patterns. As the focus of interests moves from parents and other siblings to peers outside the home, some rather important adjustments have to be made in the family. With the onset of adolescence, and throughout its course unt1l early adulthood, the one persistent direction is that of moving away from parents and toward the establishment of personal nuclear families. In some famflies this tradition is gradual and natural. In others, this period is very traumatic and stormy.

The family exerts maximum influence in the early years of the child's life, but socialization during adolescence takes a different form. Socialization for the adolescent is to reach out as well as to grow out of the family. This is a very crucial period when the adolescent must establish his own identity. There is within the adolescent a constant desire for establishing an inner sense of continuity so that his adulthood is consistent with his present life. Failure on the part of the adolescent to find his place in the day-to-day scheme of things often constitutes what Erikson (1968) refers to as an "identity crisis."

\section{Adolescent Autonomy}

Douvan and Adelson (1966) described the adolescent effort toward independence as the keystone of famlly relations and gave this phenomenon the status of a traditional, mythical model for adolescent behavior. 
In folklore and herolc flction, we find the recurring pattern--the adolescent hero, having recelved some sign, an inner stirring, or an outer call, gets ready to leave the family. The paths of departure may vary. Some must struggle to leave, others must flee for their lives; some leave vindictively, full of hate, thrashing the father or mother, while others are themselves beaten or betrayed before they leave; some leave in high expectation, carrylng the family's hope for fortune or redemption, and others leave at dead of night, in disgrace, bearing the family's curse. The hero's journey begins with an ending--the breaking of the connection to home (Douvan and Adelson, 1966, p. 19).

Jersild (1963) suggested that family relations take the form of a three-act drama. The adolescent is at first dependent on his parents, but is beginning to see them as ordinary human belngs. The "struggle for emancipation" comes as a second act, when the adolescent outgrows his dependence and transfers his major loyalties to his prospective mate. In the third act, the struggle is "supposed to" die out as the former adolescent finds an adult role, and parents become peers--respected or not, as the case may be.

In considering the relationship between the adolescent and his family, the frame of reference commonly used is that of the parent viewing the adolescent. Musgrove's studies (1966), using the sentence-completion test to assess parent and adolescent attitudes, showed that the number of favorable statements concerning parents of the same sex decreased with age for both sexes. However, the important finding is that the adults exhibited a greater degree of hostility toward adolescents than adolescents did toward adults. This finding was consistent with similar work done by Eppel and Eppel (1962) and Hess and Goldblatt (1957). 


\section{Adolescent Conflict}

In a family situation, conflicts arise when both parents and adolescents want autonomy but perceive it differently. Sobanska (1965) studied relationships between adolescents and their parents by analyzing three hundred essays written by twelve- to eighteenyear olds. Her analysis showed that 78 per cent of the group felt that their relationships with parents were somewhat unsatisfactory. This was due to conflicts. The chlef source of conflict for the fifteen- to sixteen-year-old age group was their inability to get along with one of the parents. The quest for independence was the main source of conflict for girls between thirteen and fifteen years old. All the adolescents in her study suggested specific home practices like providing a democratic atmosphere, weaning from parental control, and helping them to develop more self-control so that tension and conflict could be reduced between the two generations.

In the research findings of Musgrove (1964) and Bowerman \& Kinch (1959), it was found that, when conflict existed between parents and adolescents, it was greater and lasted longer in boys than in girls and most of the evidence pointed to the peak age of conflict as between fifteen and seventeen years.

Douvan and Adelson (1966) showed that, in girls of different age groupings, there was a progression of conflicts from narcissistic difficulties in early adolescence, to interpersonal issues in mid-adolescence, and to Ideas and values in late adolescence. Both sexes struggled for independence but in different 
ways. For boys, Independence was freedom from constraints, and the freedom in life to behave as one wished. For girls, Independence represented internal freedom--the opportunity to be one's self and to have some autonony with respect to one's feelings and thoughts.

Elkind (1968) suggested that the parent-adolescent conflict was part of the child's development toward self-differentiation. He said that issues arose when any of the three following kinds of contractual agreements or arrangements were violated:

1. Bargain--reward or punishment for compliance

2. Agreement--more complex and longer lasting, where the parties had to abide by certain rules over a period of time

3. Contract--process whereby parents and children interacted on the basis of mutual expectations These agreements symbolized for both parties the happy balance between responsibility and freedom, achlevement and support, as well. as loyalty and commitment.

Douvan and Adelson (1966) further stated that family dynamics had profound effects on the adolescent's development toward maturity and freedom. This included the parents' Interest and involvement In their parental role, the affective intensity of family interaction, the degree of family conflict, and the extent of parental authority and control.

Davis's. (1971) studies showed the effect of environmental factors upon family dynamics. He cited factors like (1) the rapid 
pace of change in the country, (2) the physiological differences between adolescents and parents, (3) the psychosocial differences, and (4) sociologlcal difierences where soclety prescribes an authority role to parents and a subordinate position to the youth. All these differences provided conflicts between adolescents and thelr families.

Besides Davis's environmental factors on family conflicts, Keniston (1962) and Erikson (1963) viewed western civilization as affecting the unfversal parent-adolescent relationship. Among the cultural factors they saw influencing this relationship were (1) conflicting norms and inconsistent codes of morality between the two generations, (2) the competition by intrafamilial and extrafamilial authorities to guide the youth, (3) a lack of an established process of adfustment for adult life, and (4) the decreasing size of families.

\section{Influences on the Adolescent's Perception of the Family}

Because of the nature of family dynamics, adolescents perceive their family differently than do their parents. Meissner's (1965) study showed that youngsters had a higher opinton of their parents than the parents did of themselves. The majority of the adolescents in one study (Maxwe11, Conners, \& Walters, 1961) rated parent-adolescent relationships more favorably than did either father or mother. Kirkpatrick (1967) stated that the perception of the family was colored to a certain extent by the adolescent's own needs. Studies using responses by adolescents 
to the Breznutz-Rufelmas Prediction Scale showed that Eathers were perceived as instrumental while mothers were perceived as "expressive" (Dahlemn, 1970).

When different cultures were examined, it was found that perceptions of the home or family varled greatly. White American boys saw their homes as being consistently mare strict than their black contemporaries percetved thetrs (Schab, 1971). On the other hand, similar studies conducted among Ghanatan adolescents revealed that parents were perceived as being more "kind, affectionate, cheerful, and Instrumental" (McInt1re, 1974). Wheeler's (1960) study on Australlan adolescents' views of their parents as expressed In essays revealed that, in areas of friendship, the students felt that their parents should scrutinize their friends carefully but not interfere with their choice. They wanted parents they could confide In with their emotional problens. They wanted parents to refrain from teasing them about their friends and from exposing them to embarrassment or humiliation in front of their friends. Some thought parents should rely on the adolescents' good sense for late hours, while others preferred fixed times to be home. They wanted parents to help them develop confidence about new social situations. They felt that sex education was needed in the home where they would benefit from parental help and advice. They wanted their parents to keep pace with the world. Parental attributes that were most prized were tolerance and understanding, and dislike was expressed for parents who were inconsistent and arbitrary in their relationships with their children. 
Development of the Family Concept

Several factors or influences contribute to the development of the concept of family in adolescents. Singly, or in combination, each of these plays a part in the formation of attitudes and perceptions of youth.

When the socialization variable of the California Personallty Inventory (CPI) was used as a criterion in the comparison of the family concepts of subjects grouped according to high or low schooladfustment rankings, hypotheses regarding positive relationships between family concept measures and child personality variables were supported, espectally for the CPI measure of socialization (Saller, 1967). Further, van der Veen and Haberland's (1971) study Indicated that, where there were family satisfaction and harmony, there was greater congruence between the views of parents and those of their adolescent offspring. Further, communication between the two parties was deemed most important. Chaffee, McLoud and Atkin (1971) found that families with simflar parent-child communication structures indirectly produced characteristic media-use (television, prints, and broadcasting) patterns that, on the average, were shared by parents and adolescents.

Factors Influencing the Family Concept

Several influences contribute to the development of the family concept in adolescents.

Schools and institutions. In schools where family-life education was offered, adolescents showed an increased know- 
ledge of family life but there was no change in their attitude toward their family (Crosby, 1971). In another study involving family and institutionalized adolescents, it was found that the latter had negative attltudes toward their marriage role-expectations (Snow, 1973).

Schools can function as a social system to foster the development of capacity that will enable persons to be in charge of their own lives. Coleman's (1973) Family Building Model was presented as a way of looking at adolescent development. This enabled educators to determine knowledge, attitudes, and skills which adolescents needed to master in preparation for one critical domain of their future lives--the family.

Family concept or Image has been part of the reading process. The 1968 serles of basal readers used in most elementary schools presented a family image essentially of northern, suburban, upper-middle-class Americans with three children under seven years of age, and a dog (Lorenz, 1970). In cooperation with textbook publishers, schools can, and probably do, influence changes in attitudes toward the family even though the description of the basic family and its community may differ considerably from the statistical representation of the average American family and its community. Nevertheless it can be concluded that schools and institutions do play a part, howbelt small.

Home background. It has been found that social class and family backgrounds do make an impact on the adolescent's concept of the family. Among black adolescents two variables signif- 
Iffcantly affected their marrlage role-expectations (Rooks \& $\mathrm{King}$, 1973). Significant differences in marriage role-expectations were found between males from broken homes and males from intact middleand lower-class homes. Females were more traditional than males regarding housekeeping. Stone and Slocum's (1959) study indicated that there was a relationship between the Images which teenagers have of their families as reference groups and their observed behavior. Family power structure. . It has been observed that

fathers and their place in the power structure of the family play an important part in the development of the adolescent's family concept (Bowerman \& Elder, 1964; KIng, 1969; Herzog \& Sudia, 1968). Most children attribute greater power to the father, although they perceive an egalitarian power pattern in their families (Larson, 1974). Another study (Sailer, 1967) showed that boys with high scholastic performances perceived their fathers as most powerful in decision-making, though they were democratic in parent-child relationships. Results of King's (1969) study indicated that both male and female black adolescents viewed the power structure of their families to be mainly syncretic. The males in the sample reported stronger father participation than the females did. Both males and females indicated stronger participation in decision-making than had been historically presented.

Congruence between adolescent and parent famlly concepts was found to be greater when the father was perceived to be more dominant and assertive, and also when there was less conflict between mother and child (van der Veen, 1974). 
Emotional stability. The disturbed adolescent usually has a distorted family concept (Fodor, 1973; Vogel \& Lauterback, 1963; Novak \& van der Veen, 1970). Findings from these studies suggest that the psychopath views his father as having been less nurturant toward him while his mother demands less achievement from him, and that problem boys have a hostile perception of their fathers but not of their mothers. Haldle's (1974) study indicated that there is a difference in the way non-delinquents and delinquents perceive their parents, family, home, and themselves. In his conclusion he stressed that parents have a great influence upon the development of their children and that parents tend to react to the apparent needs of their children rather than to listen to the real need the child is trying to express.

Hewitt's (1967) study on culturally deprived adolescents found that family problems percelved by culturally deprived boys are significantly related to a sense of extrafamilial "homeyness" (family adjustment). Adolescent boys from a culturally deprived home seem to percelve problems in the family. Culturally deprived adolescents experience less homey feelings than other boys of similar ages.

Conversely, it has been found that the highest level of satisfaction and adjustment is found in normal families with we11-adjusted children (Novak \& van der Veen, 1969, 1970).

\section{Summary of the Chapter}

Three major approaches to the study of the family--the structural-functional approach, the interactional and situational 
approach, and the developmental approach, with special emphasis on the models of familfal socialization, were reviewed in this chapter.

Parent-adolescent relationships are developed through socialization--an interactional growth process through prolonged exposure to each other. Conflict, struggles for adolescent autonomy, and experiences in parent-child relations as part of growing up, all contribute to the conceptualization of the type of family ideally perceived by the adolescent.

Several factors contribute to the development of the family concept in adolescence. Besides the socialization factor within the family, the school, in the courses offered and the books used, seems to play an important role. The family background, soclal class, and race all apparently affect the family concept. The emotional stability of the parents and the way parents govern the family also contribute to the development of the family concept.

\section{Tentative Conclusions}

Throughout the literature, the research and approaches reveal substantial evidence that the adolescent's family concept is influenced by his home relationships, school, family background, and the emotional stability of the parents. From this review, two broad hypotheses are defined for testing and further study:

1. The concept of the ideal family as held by adolescents can be described in terms of a number of basic factors.

2. There is a significant difference in the ideal family concepts of adolescents of various sub-groups. 
a. There is a significant difference in ideal family concepts between adolescents in grades nine and twelve.

b. There is a significant difference in Ideal family concepts between Seventh-day Adventist and nonSeventh-day Adventist adolescents.

c. There is a significant difference in ideal family concepts between male and female adolescents.

d. There is a significant difference in ideal family concepts between white and non-white adolescents.

e. There is a significant difference in ideal family concepts among rural, urban, and suburban adolescents.

f. There is a significant difference in ideal family concepts between adolescents from two-parent and one-parent families. 
CHAPTER III

\section{RESEARCH DESIGN AND METHODOLOGY}

This was a descriptive study, the purpose of which was to Identify the types of family concepts held by different groups of adolescents. Several statistical techniques were used.

This chapter describes the research design, the datagathering instrument, fleld procedures, and the data-analysis techniques used.

\section{Research Design}

\section{Independent Variables}

Seven independent variables and their classiflcations were chosen: (1) grade In school--ninth and twelfth grades, (2) church membership--Seventh-day Adventists and non-Seventh-day Adventists, (3) sex--male and female, (4) race--white and non-white, (5) residential location--rural, urban, and suburban, and (6) parental number--both-parents and one-parent.

\section{Dependent Variables}

The scores on the eighty-item Family Unit Inventory (see appendix A) were used as dependent variables. Among these items, twelve factors were isolated which identifled adolescents' perceptions of the Ideal family. These factors then formed twelve dependent varlables with factor scores on which the effects of the independent 
varlables were tested. Further, they served as bases for comparisons with those identifled by van der Veen and his associates.

\section{Statement of Hypotheses}

Seven hypotheses were advanced for testing. Hypotheses

2 to 7 are stated in the null form for the sake of statistical tests.

1. The concept of the ideal family as held by adolescents can be described in terms of a number of basic factors.

2. There is no significant difference between the:

a. means of the ideal famtly concept scores of adoleseents in grades nine and twelve.

b. centroids of the Ideal family concept factor scores of adolescents in grades nine and twelve.

3. There is no significant difference between the:

a. means of the ideal family concept scores of Seventh-day Adventist and non-Seventh-day Adventist adolescents.

b. centroids of the ideal family concept factor scores of Seventh-day Adventist and non-Seventh-day Adventist adolescents.

4. There is no significant difference between the:

a. means of the Ideal family concept scores of male and female adolescents.

b. centrolds of the ideal family concept factor scores of male and female adolescents. 
5. There is no significant difference between the: a. means of the ideal family concept scores of white and non-white adolescents.

b. centrolds of the ideal family concept factor scores of white and non-white adolescents.

6. There is no significant difference among the:

a. means of the ideal family concept scores of rural, urban, and suburban adolescents.

b. centroids of the ideal family concept factor scores of rural, urban, and suburban adolescents.

7. There is no significant difference between the: a. means of the ideal fimily concept scores of adolescents from two-parent and one-parent families.

b. centroids of the ideal family concept factor scores of adolescents from two-parent and oneparent families.

\section{Instrumentation}

Van der Veen's Family Unit Inventory (FUI)

This study employed the standardized Family Unit Inventory (FUI) developed by Ferdinand van der Veen of the Chicago Institute of Juvenile Research. This Instrument was constructed for adolescents and had been used to test adults' family concepts as well. Its advantages lay in its simplictty for group administration, versatility and variety of 1tems, and the economy of time on the 
part of the test-taker. Further, van der Veen had demonstrated that the instrument objectively measured a person's perception of his family as a unit. This was relevant and pertinent to this Investigation. With the permission of van der Veen, a change was made in the layout of the test (see appendix A).

The FUI consists of two identical forms of 80 items or statements on the feelings the respondents have about the famlly. Form RIF requests the description of the actual family, whereas Form IF examines the ideal family concept. This study used the Form IF to identify the Ideal family concept of the adolescents. Each statement in the Family Unit Inventory is accompanied by a nine-point L'kert scale from "least like" to "most like" the Ideal family. The subject is asked to circle the number that shows how true the Item is for his family as he would ideally like it to be. Items are stated in positive and negative forms.

Demographic data needed for the study were requested on the first page of the instrument together with the instructions. To preserve anonymlty, subjects were not asked to write their names on the instrument. Most of the information to be entered in the computer for later analysis was numerically coded.

\section{Development of the Instrument by} van der Veen

The Family Unit Inventory. This instrument was developed by van der Veen In 1961 for obtaining a quantifiable description of an individual's family concept.

Formats. The FUI evolved through three formats. The or 1ginal format was the Family Concept Q-Sort which consisted of eighty 
items that were descriptive of the family unit. The items described the entire family unit, not individual relationships.within the family. It was expected that in this way the most sallent aspects of a person's family experience would be obtained regardless of the specific relationships involved.

The Q-Sort was also used to describe different kinds of family perceptions, and sorted along a quasi-normal distribution with a fixed number of items in each of the nine piles, from "least like" to "most 1ike." The score assigned to any given Item was the number of the pile (from 0 to 8 ) in which it was placed.

Since the Q-Sort format was too time-consuming and could be done only on an individual basis, two other response formats were developed. The first was a multiple-choice form in which Items were printed in a booklet and the subjects were asked to answer each item on a nine-point scale (0 to 8). The second was a truefalse form which required subjects to circle elther " $T$ " (scored 8) or "F" (scored 0) for each item in the test booklet (van der Veen, Howard, and Austria, 1970).

Van der Veen also developed some global scores for this test such as: (1) the Family Adjustment Score--the agreement between a person's real family concept and the professional clinician's (social worker, psychologist, and psychiatrist) concept of the Ideal family, (2) the Family Satisfaction Score--the agreement between a person's real family concept and his ideal family concept, (3) the Family Congruence Score--the agreement between the real family concepts of the father and the mother, and (4) the Family 
Compatibility Score--the agreement between the ideal family concepts of the father and the mother.

Studies on format. Van der Veen, et. al. (1970) compared the three commonly used response formats--Q-Sort, Multiple Choice, and True-False. The different test forms correlated almost as well with each other as with themselves. The multiple-cholce form showed the highest stability--test-retest rellability coefficients ranged from .78 to .95-and ylelded slightly higher correlations with other forms.

The format used in this study. The multiple-choice form was used in the present study since (1) simultaneous administration to several subjects was required, and (2) the multiple-choice form gave the best results in terms of test-retest reliability.

\section{Reliability and Validity}

The reliability and validity of the Q-Sort as a measure of family functioning were investigated in several studies (van der Veen, M. \& Ostrander, 1961; van der Veen, F., Ostrander, \& van der Veen, M., 1961). These studies showed that family descriptions using the Q-Sort were adequately reliable over even falrly long spans of time.

Reliablity coefficlents determined by a median test-retest correlation for ten clinic waiting-list parents over a four-week period were .71 and .80 for real and ideal family concepts respectively. The test-retest correlations were $.51, .39, .66$, and .63 for the family adjustment, family satisfaction, family congruence, 
and family compatiblity scores of the lower adjustment groups. All subjects used were from clinical and low-adjustment groups. Other Studies on the FUI

In an item analysis, using three groups of ten parents each (clinic, non-clinic low adjustment, and non-clinic high adjustment), significant Item differences between groups were found on 34 items (Beckowtt2, 1963). In another sample of 25 adolescents used to test social desirability of the items, the Q-Sort was compared with two California Personality Inventory scales (Good Impression and Self Control). The Good Impression scale was related to 13 of the 80 items and the Self Control scale to 22 items. Soclal desirability was a factor, but the degree or influence of this factor was underermined (Crandall, 1968).

Gther studies employing the FUI Investigated the relationship between the family concepts of fathers, mothers, and children and ch11d development (Novak \& van der Veen, 1970, 1974; van der Veen, 1965; van der Veen et. al., 1964), marital adjustment (KImmel, 1970; van der Veen, 1964), child type--aggressive versus withdrawn (Jansen, 1972), school achievement (Strauss, 1970), parental attitudes (van der Veen \& Novak, 1971), and family Intervention methods (Hardcastle, 1973; Raskin \& van der Veen, 1970; Reiter \& KIlmann, 1975; Wattie,-1973). These studies focused on the global types of variables such as family congruence, family satisfaction, family adjustment or effectiveness, and family compatibility. Little research has been done on the environmental factors influencing the family concept, such as school, 
grade in school, church membership, sex, race, residential location, and parental number.

From his investigations, van der Veen isolated nine factors that made up the concept of the Ideal family. These were:

(1) consideration vs. conflict, (2) family actualization vs.

Inadequacy, (3) open communication, (4) community sociability,

(5) family ambition, (6) internal vs. external focus of control,

(7) togetherness vs. separateness, (8) Family loyalty, and

(9) closeness vs. estrangement.

\section{Field Procedures and Data-Gathering}

P1lot Study

Study on data-gathering procedure. A pilot study was conducted to refine the research destgn. On March 31, 1976 the FUI was administered to 41 adolescents at Andrews Univers1ty Academy. This group was made up of 20 twelfth graders and 21 ninth graders. The procedures for administering the inventory were tested. This pilot sample was divided into two groups:? one where instructions were carefully read aloud, and the other where instructions were not read aloud. No difference was found between the two group means.

The timing for the administration and completion of the instrument was studied at this point. The eighty-item test took an average of ten to fifteen minutes to complete.

Study on data-analysis procedure. The sample data from the 41 students were used to assess the procedure for analysis. An item analysis yielded an estimate of the reliability of the test (reliability coefficient alpha) as .885 . Medians for each 
Item were also calculated to establish how they were to be scored. Those items with a median of 5 and above (on a nine-point scale) were considered positive items while those with a median of 4 and below were classifled as negative. These negative items were later scored in the reverse. The final list of positive and negative items corresponded with van der Veen's (see appendix B). The data were also used to refine computer procedures for factor analysis and discriminant analysis.

\section{Population and Sample}

The sample of 123 subjects was drawn from secondary schools in Illinois, Indiana, and Michigan. The study was Iimited geographically in relation to the location of Seventh-day Adventist academies, which included Broadview Academy at La Fox, Illinols; Shiloh Academy at Chicago. Illinois; Indiana Academy at Cicero, Indiana; Adelphian Academy at Holly, Michigan; Cedar Lake Academy at Cedar Lake, Michigan; Grand Ledge Academy at Grand Ledge, Michigan; and Frank Peterson Academy at Detroit, Michigan. A public sentor high school in the vicinity of each academy was chosen as the source of non-Seventh-day Adventist subjects.

\section{Method of Approaching Principals}

The pilot study explored the efficiency and effectiveness of obtaining the cooperation of secondary school principals. With the Seventh-day Adventist principals one or two prior contacts were found to be important. With the other school principals no previous arrangements were made. From the public schools, 85 per cent of the 
principals approached cooperated. The others could not comply with the request because of school vacations and busy end-of-the-year programs.

A brief synopsis of the intent of the study was made to the school principals in order to gain their sooperation. After a description of the purposes was given, a request was made for approximately ten students to be selected by random number tables for participation in the study. Registrars and guidance personnel assisted in providing the lists of names and in summoning the students for the test.

\section{Administration of the FUI}

Procedure. In most cases, the test was administered in the library, study hall, empty classroom, or cafeterla by the writer. The instructions were read together and a request to f1ll in the personal information was emphasized before the subjects proceeded with the test.

The administrator sat with the whole group unt1l the last subject completed the test. Each completed form was carefully checked for accuracy before the subject was allowed to leare the place of testing.

Data-gathering in an average of only two schools per day was achleved because some of the seniors had to leave for vocational schools or work programs in the afternoon.

Selection of subjects. By using random number tables and an alphabetical Iisting of all the seniors and freshmen enrolled in the school, approximately five sentors and five freshmen were 
chosen. In two cases, the principals randomly selected the subjects. This procedure ylelded a representative group of adolescents for each of the thirteen schools. The breakdown of the characteristics of the subjects is shown on table 1 .

TABLE 1

CHARACTERISTICS OF THE SAMPLE

By Schools

Seventh-day Adventist Academies 7

Public Senior High Schools 6

By Grade in School

Ninth Grade 61

Twelf th Grade $\quad 62$

By Church Membership

Seventh-day Adventists (SDA) 70

Non-SDA (includes Catholic,

Protestants, and others) 53

By Sex

Male 66

Female $\quad 57$

By Race

White $\quad 87$

Non-white $\quad 35$

By Residential Location

Rural

49

Urban $\quad 44$

Suburban $\quad 30$

$\frac{\text { By Parental Number }}{\text { Both parents }} \quad 78$

One parent $\quad 22$

Others* 23

*Note: These 23 subjects were dormitory students, and because they were not living with their parents at the time of the study, were not included in the analysis by parental number. 
Data Recording, Processing, and Analysis

\section{Data Recording}

The responses of the Items by the respondents were assumed to constitute their ideal family concepts, and these responses were translated into a format convenient for data entry into the computer for analysis.

\section{Data Entry}

The data were entered on-line at a computer terminal. A simple basic format was used. Colums 1 through 7 listed the independent varlables: type of school, grade in school, church membership, sex, race, residential location, and parental number. Colums 8 through 87 recorded the scores on the 80 items of the FUI.

\section{Data Analysis}

The responses were first scored and the total scores for each student on each Item were recorded in a new data file, forming the basic data for factor analysis. (see appendix $\mathrm{C}$ ).

The t-test used the total scores of the students on the complete test of 80 items to find the differences between the group means where there were two levels. Where there were three levels (for hypotheses $6 a$ and $6 b$ ) one-way analysis of variance (ANOVA) was performed to determine any significant difference between the groups.

From the file of student scores on the 80 items, an 80 X 80 correlation matrix (appendix D) of inter-item correlations was obtained. After this, factor analysis with Varimax rotation was undertaken to seek a logical number of factors. The most 
meaningful organization was evident when twelve factors were rotated.

A panel of experts consisting of psychologists, sociologists, family life educators, home economists, a statistician, and a counselor was requested to study the 1tem loadings on each of the twelve factors and to select the most approprlate name from a list of three to five alternatives suggested for each factor. Factor scores of subjects on the twelve factors were stored in a new data file for multivariate and discriminant analyses. Three-way and four-way analyses of variance were also attempted on the twelve factor scores. However, because the cell frequencles were too small and uneven to yield meaningful data, this statistical procedure was not pursued. 
CHAPTER IV

\section{PRESENTATION OF FINDINGS}

This chapter presents the findings from the analyses of the information collected from 123 adolescents randomly chosen from ninth and twelfth grades in selected Seventh-day Adventist academies and public high schools in Illinois, Indiana, and Michigan. The chapter is organized into three sections:

1. Dimensions of the Ideal family concept

2. Differences between the subgroups

3. Discussion of findings

\section{Dimensions of the Ideal Family Concept}

Intially the responses of the 123 subjects were scored and a total test score (a maximum of 720 ) was obtained for each subject. A listing of the total scores is found In appendix $C$. Using the scores of the 123 subjects on the 80 items of the rest, an $80 \times 80$ matrix of inter-item correlations was obtained (see appendix D). The intercorrelation matrix was subjected to principal components analysis followed by varimax rotation, using the BMDX72 program. Various numbers of factors were rotated and the results were studied for the most meaningful groupings or dimenstons.

A rotation of twelve factors resulted in the most interpretable matrix of factor loadings. These twelve factors, with eigen- 
values ranging from 18.65 to 1.57 accounted for 58 percent of the total varlance.

The $80 \times 12$ matrix of rotated factor loadings of the items is given in appendix E, and the $123 \times 12$ matrix of factor scores of each individual is given in appendix F. These matrices, together with the total test scores of the 123 subjects, formed the bases for further analyses.

In the process of relating an item to a factor, for the purpose of identifying the factor, loadings less than . 35 were ignored. The panel of experts were presented with a listing of the items with major loadings on each factor and by vote were able to name the factor.

The adolescent concept of the ideal family is therefore described in terms of twelve identifiable independent dimensions. For each of these dimensions (factors), the 1tems are listed with their loadings in ranking order by absolute value (see tables 2 through 13). A discussion of the main features of each factor leads to an identification of that factor by name.

Factor I. Table 2 shows the 1tem number, 1tem, and item loadings on the factor. High item loadings represent a high correlation between the item and Factor I. This factor had all positive 1tem loadings. In viewing the ideal family, the subjects outlined the family's need for each other, the importance of the family as a unit, and the support and care upon which family members could depend. A descriptor suggested to summarize all the items in the factor is Attachment. 
TABLE 2

ITEM LOADINGS ON FACTOR I

\begin{tabular}{|c|c|c|}
\hline tem No. & Item & Item Loadings \\
\hline $\begin{array}{l}35 \\
48 \\
43 \\
46 \\
19 \\
41 \\
7 \\
70 \\
14 \\
39\end{array}$ & $\begin{array}{l}\text { We need each other } \\
\text { The family has always been very important } \\
\text { to us } \\
\text { Together we can overcome almost any } \\
\text { difficulty } \\
\text { We take care of each other } \\
\text { We often praise or compliment each other } \\
\text { We have warm, close relationships with } \\
\text { each other } \\
\text { We feel secure (safe) when we are with } \\
\text { each other } \\
\text { We are a strong, competent (able) family } \\
\text { We are an affectionate family (show our } \\
\text { love for each other) } \\
\text { We encourage each other to develop in his } \\
\text { or her own individual way } \\
\text { We respect each other's privacy } \\
\text { We forgive each other easily }\end{array}$ & $\begin{array}{l}.70228 \\
.67804 \\
.59328 \\
.57758 \\
.57454 \\
.56809 \\
.56286 \\
.55566 \\
.53199 \\
.49629 \\
.46521 \\
.36463\end{array}$ \\
\hline
\end{tabular}

Factor II. Table 3 presents the Items with high positive and negative loadings on Factor II. Note that a negative loading on a particular item should be read as though it were a positive loading on the reverse statement of the item. For example, item 40 would read as "we are not ashamed of some things about our family" with a loading of +.73289 on Factor II.

Several items have an $R$ following the item number. These are items which the item analysis in the pilot study suggested as befing statements requiring reverse scoring. That is, maximum points were given for "least 11ke" and minimum points were given for "most like." For example, in 1tem 29, the high score indicates 
that "accomplishing what we want to do does not seem to be difficult for us" is read as having a loading of .66452 .

TABLE 3

ITEM LOADINGS ON FACTOR II

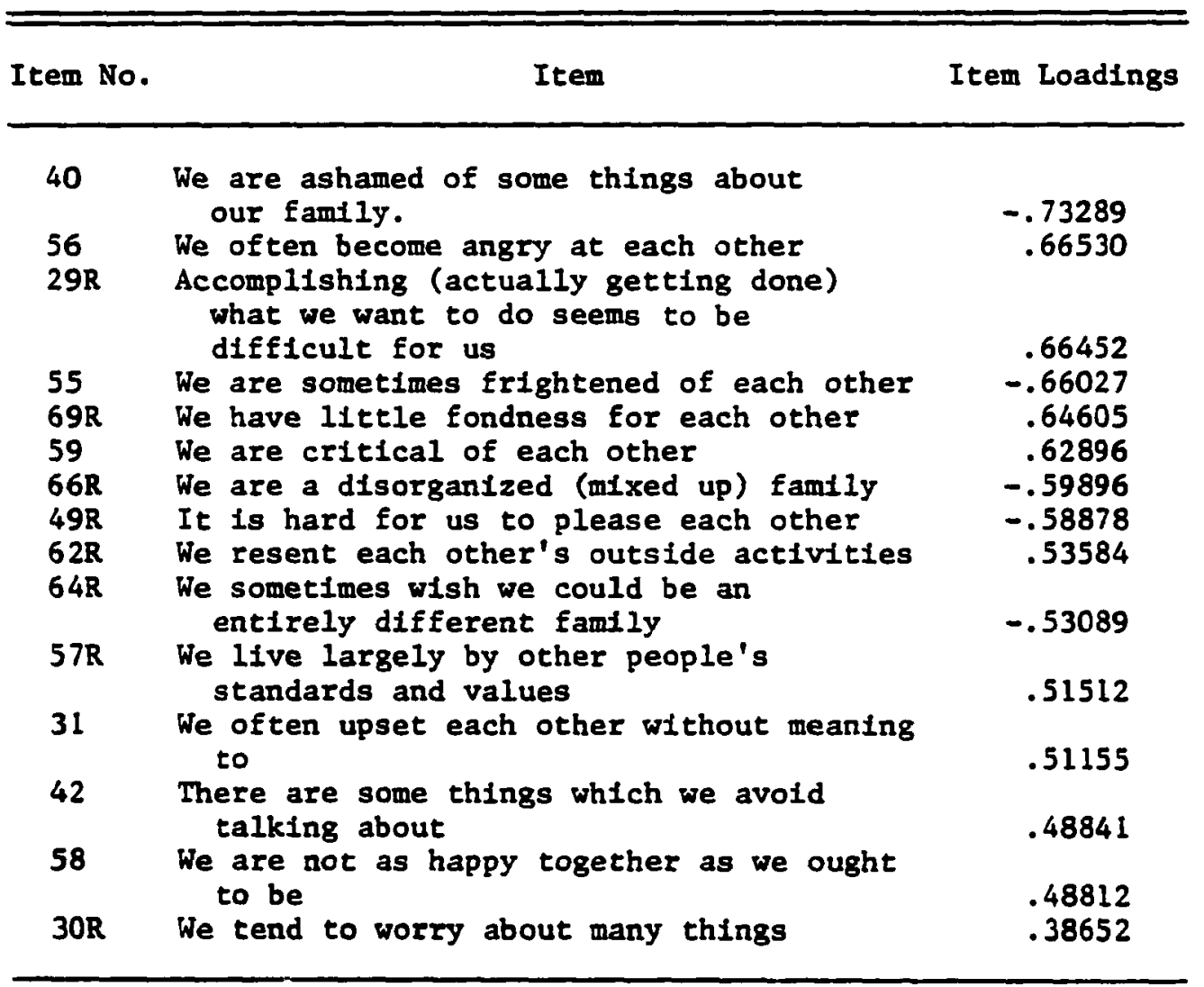

A few items involve both of these negatives. For example, Item 66 has an $R$ and also a negative loading. In considering the relationship between the item and the factor the two negatives will be cancelled. That is, the statement "we are a disorganized family" will have a loading of +.59896 on Factor II. Applying this procedure in studying the major 1 tem and factor loadings on this factor, conflicting characteristics that 
were filled with emotion were found. They were not ashamed of things about their family. There was anger, unhampered accomplishment, absence of fear, suspicion, fondness for, and also a critical attitude toward each other in the family. This factor may be described as Emotional Openness.

Factor III. Table 4 shows item loadings on this factor as being all positive. The ttems suggested family unity in decisionmaking, growth in the knowledge of each other, having good times together, and the ability to adjust to new situations with trust and confidence in each other. These Ideas together suggest Compatibility as a descriptor for Factor III.

TABLE 4

ITEM LOADINGS ON FACTOR III

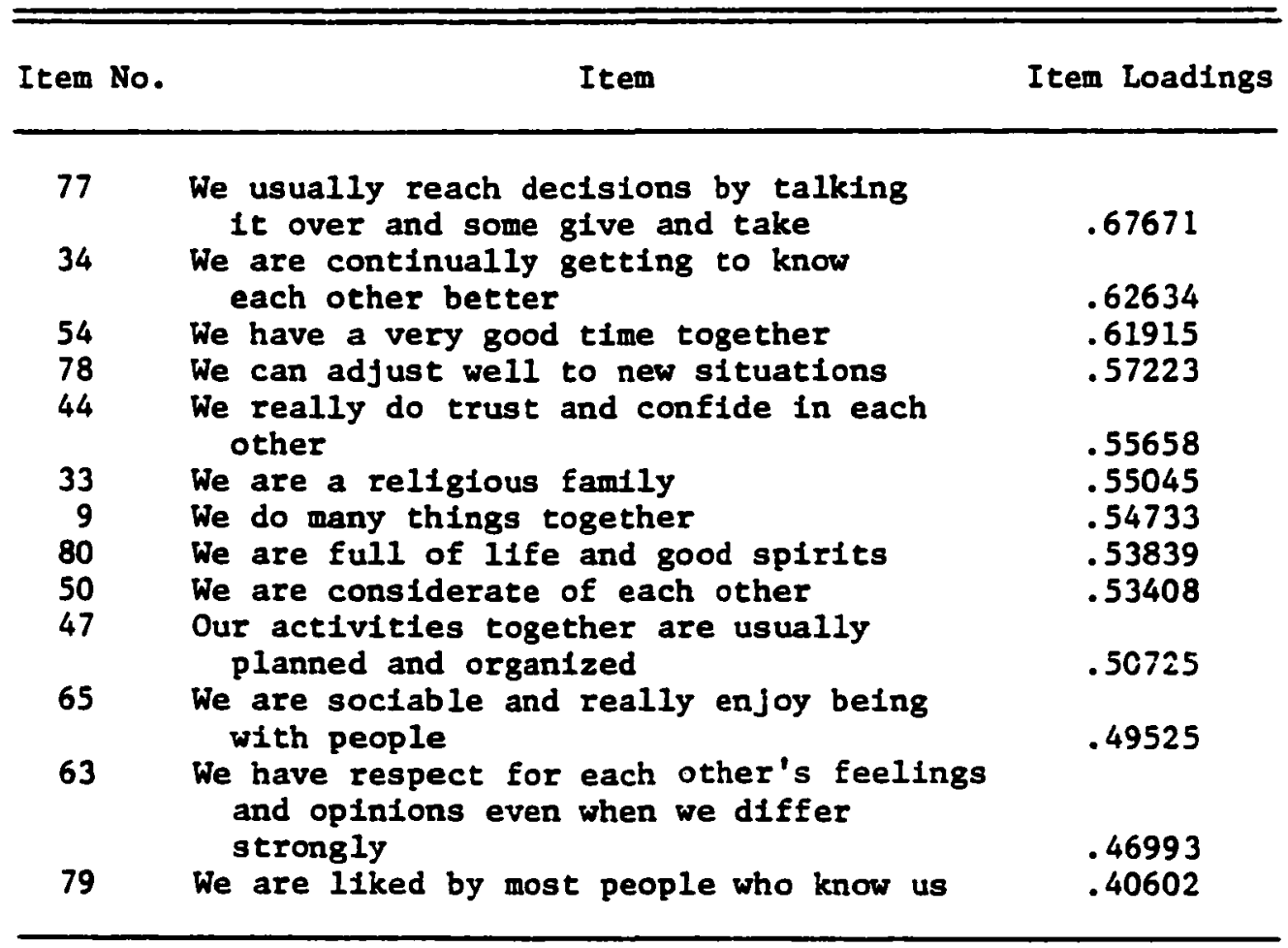


Factor IV. The items loading highly on this factor as listed in table 5 show a somewhat conflicting picture initially. The adolescents viewed their ideal family as one that recognized its need for help, yet was not too proud or hampered by tradition or etiquette to ask for assistance.. Factor II may be characterized as Inadequacy.

\section{TABLE 5}

ITEM LOADINGS ON FACTOR IV

\begin{tabular}{|c|c|c|}
\hline Item No. & Item & Item Loadings \\
\hline $\begin{array}{r}8 \\
23 \\
6\end{array}$ & $\begin{array}{l}\text { We want help with our problems } \\
\text { We are proud of our family } \\
\text { Good manners and proper behavior } \\
\text { are very important to us }\end{array}$ & $\begin{array}{r}.56838 \\
-.56460 \\
-.49291\end{array}$ \\
\hline
\end{tabular}

Factor V. Item loadings on this factor, in table 6, were both positive and negative. The ideal family was viewed as one that did not need to be perfect before its members could be satisfied, and where total agreement on important matters was not deemed necessary. The Ideal famtly was not viewed as talkative and of ten avoided sensitive subjects like sexual matters. It was suggested bv the panel that all these ideas indicate a solrit of Individuality.

Factor VI. In table 7, item loadings were mainly positive for this factor. The 1deal family was viewed as being satisfied with 1tself. Emphasis was placed on the family's appearance to the communtty, and the willingness of each member to cooperate and accept 
responsibility for family matters. This factor was described as Interdependence.

TABLE 6

ITEM LOADINGS ON FACTOR V

Item No.

Item

Item Loadings

72R We are not satisfied with anything. short of perfection $\quad .68607$

4 We often do not agree on important matters $\mathbf{. 5 2 0 5 0}$

20R We avold talking about sexual matters -.46397

27 We are not a talkative family .43846

TABLE 7

ITEM LOADINGS ON FACTOR VI

\begin{tabular}{lll} 
Item No. & Item & Item Loadings \\
\hline
\end{tabular}

60 We are satisfied with the way in which we now live

.61564

67 It is Important to us to know how we appear to others $\quad .52707$

52 We are all responstble for family matters .44473

61R Usually each of us goes his own

separate way $\quad-.41581$

18 We get along very well in the community .37874

Factor VII. This factor, as listed in table 8 , had only positive item loadings. It grouped together the Importance of encouraging (supporting) each other and being liked by others.

The name suggested to describe this factor was Mutual Support.

Factor VIII. Table 9 summarizes item loadings on this

factor as both positive and negative. The ftems include not 
accepting responsibility for difficulties realizing that there are serious differences, and the ability to gemain calm and relaxed. This factor was labelled Pseudo-confidence by the panel.

TABLE 8

ITEM LOADINGS ON FACTOR VII

\begin{tabular}{lll}
\hline \hline Item No. & Item & Item Loadings \\
\hline 75 & We hardly ever hurt each other's feelings & .68195 \\
76 & We like the same things & .46807 \\
39 & We encourage each other to develop in his & \\
79 & We are liked by most people who know us & .33205 \\
& & .30168 \\
\hline
\end{tabular}

TABLE 9

ITEM LOADINGS ON FACTOR VIII

\begin{tabular}{ccc}
\hline Item No. & Item & Item Loadings \\
\hline $15 R$ & $\begin{array}{c}\text { The difficulties that we have in the } \\
\text { family are not our fault }\end{array}$ & -.70710 \\
$11 R$ & $\begin{array}{c}\text { There are serious differences in our } \\
\text { bellef about what is right and } \\
\text { important }\end{array}$ & $\begin{array}{c}\text { We are usually calm and relaxed when we } \\
\text { are together }\end{array}$ \\
\hline
\end{tabular}

Factor IX. Table 10 gives the item loadings on this factor, which were largely negative. The factor clusters together negative ideas that connote boredom, lack of understanding of the situation, and a sense of helplessness in problem-solving, that would lead to mis- 
understanding and distrust--all situations to be avolded in the ideal family. This factor was named Frustration.

TABLE 10

ITEM LOADINGS ON FACTOR IX

\begin{tabular}{|c|c|c|}
\hline Item No. & item & Item Loadings \\
\hline $\begin{array}{l}32 \\
37 \\
51 \\
22 \\
17 R \\
24 R\end{array}$ & $\begin{array}{l}\text { Nothing exciting ever seeins to happen to us } \\
\text { We do not understand what is causing } \\
\text { our difficulties } \\
\text { We can stand up for our rights if necessary } \\
\text { If we had more money most of our present } \\
\text { problems would be gone } \\
\text { We do not understand each other } \\
\text { We do not like each other's friends }\end{array}$ & $\begin{array}{r}.72344 \\
-.56756 \\
-.51050 \\
-.49052 \\
-.43095 \\
-.40478\end{array}$ \\
\hline
\end{tabular}

Factor $X$. The item loading of each of the 1tems on this factor is 11sted in table 11. Although this factor has mixed positive and negative item loadings, the items include being reserved with each other, not allowing little problems to become big ones, too little discipline, avolding expression of real feelings, and feeling that too little time is spent together. The cluster of Ideas was best summarized with the descriptor Communication.

Factor XI. The Item loadings on this factor, shown in table 12, are both positive and negative. Here were clustered ideas of freedom that came when the family was not hampered by an overemphasis on success or family reputation and where each member refrained from running the lives of other members. There was a minimum of conflict and disagreement in the perceived ideal family. The name Autonomy was suggested by the 1tems in the factor. 
TABLE 11

ITEM LOADINGS ON FACTOR X

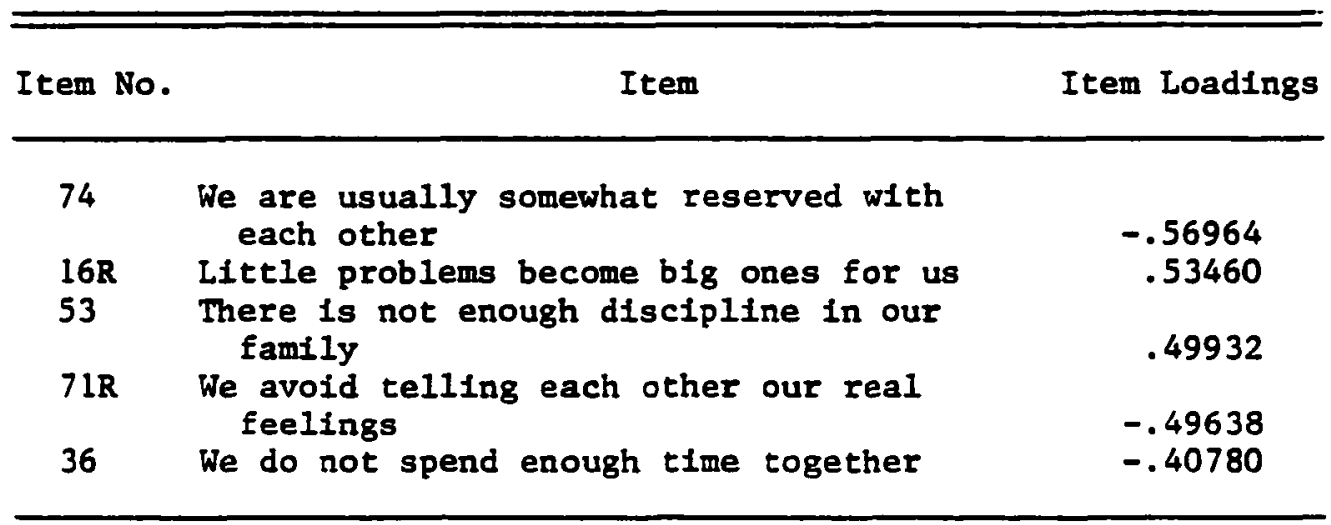

TABLE 12

ITEM LOADINGS ON FACTOR XI

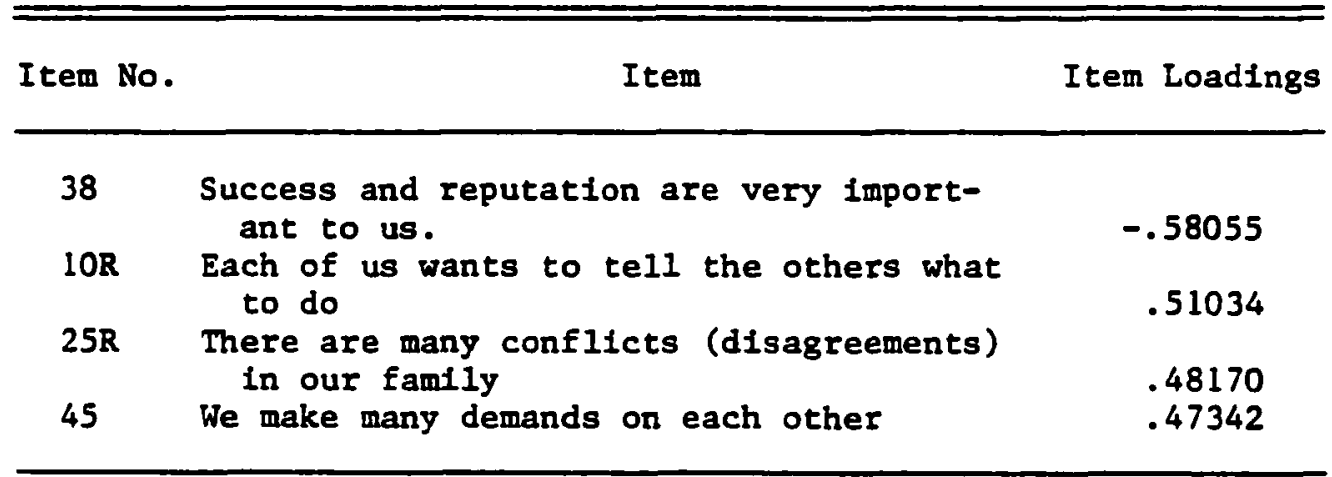

Factor XII. As shown in table 13, the 1tem loadings on this factor are all positive. They include the concepts of freedom of thought and expression, coupled with equivalent responsibility. Democracy was chosen as the term that best described this factor.

A summary and comparison with van der Veen. The twelve factors identifled in the present study were: (1) Attachment, 
(2) Emotional Openness, (3) Compatibility, (4) Inadequacy,

(5) Individuality, (6) Interdependence, (7) Mutual Support,

(8) Pseudo-confidence, (9) Frustration, (10) Comnunication,

(11) Autonomy, and (12) Democracy.

TABLE 13

TABLE LOADINGS ON FACTOR XII

\begin{tabular}{clc}
\hline \hline Item No. & Item & Item Loadings \\
\hline 12 & $\begin{array}{l}\text { We feel free to express any thought or } \\
\text { feeling to each other }\end{array}$ & .65157 \\
$68 R$ & $\begin{array}{l}\text { Our decisions are not our own, but are } \\
\text { forced upon us by things beyond our } \\
\text { control }\end{array}$ & .51444 \\
$51 R$ & $\begin{array}{l}\text { We get along much better with persons } \\
\text { outside the family than with each other } \\
\text { Each of us tries to be the kind of person } \\
\text { the others will like. }\end{array}$ & .42416 \\
\hline
\end{tabular}

While van der Veen found that nine factors adequately described the ideal family concept of his subjects, twelve were required in this study. Table 14 indicates that some factors were commonly identified in the two studies, though with different degrees of importance. For instance, van der Veen's Factor II and III were Factors IV and $X$ in this study.

In table 15, the items in the two sets of factors are compared. It is not expected that the two sets of factors would be similar because they have been derived from two very different populations. However, some similarity in item loadings on each factor is clear. It is interesting to note that items which do not load up significantly in one study do so in the other. 
TABLE 14

FACTORS IN THE CONCEPT OF THE IDEAL FAMILY AS REVEALED BY VAN DER VEEN AND BY THE STUDY

\begin{tabular}{lll}
\hline Van der Veen's Factors & Factors in this study \\
\hline 1. Consideration vs conflict & 1 Attachment \\
2. Family Actualization vs inadequacy & 2. Emotional openness \\
3. Open communication & 3. Compatibility \\
4. Community sociability & 4. Inadequacy \\
5. Family ambition & 5. Individuality \\
6. Internal vs external focus of control & 6. Interdependence \\
7. Togetherness vs separateness & 7. Mutual support \\
8. Family loyalty & 8. Pseudo-confidence \\
9. Closeness vs. estrangement & 9 . Frustration \\
& 10. Communication
\end{tabular}




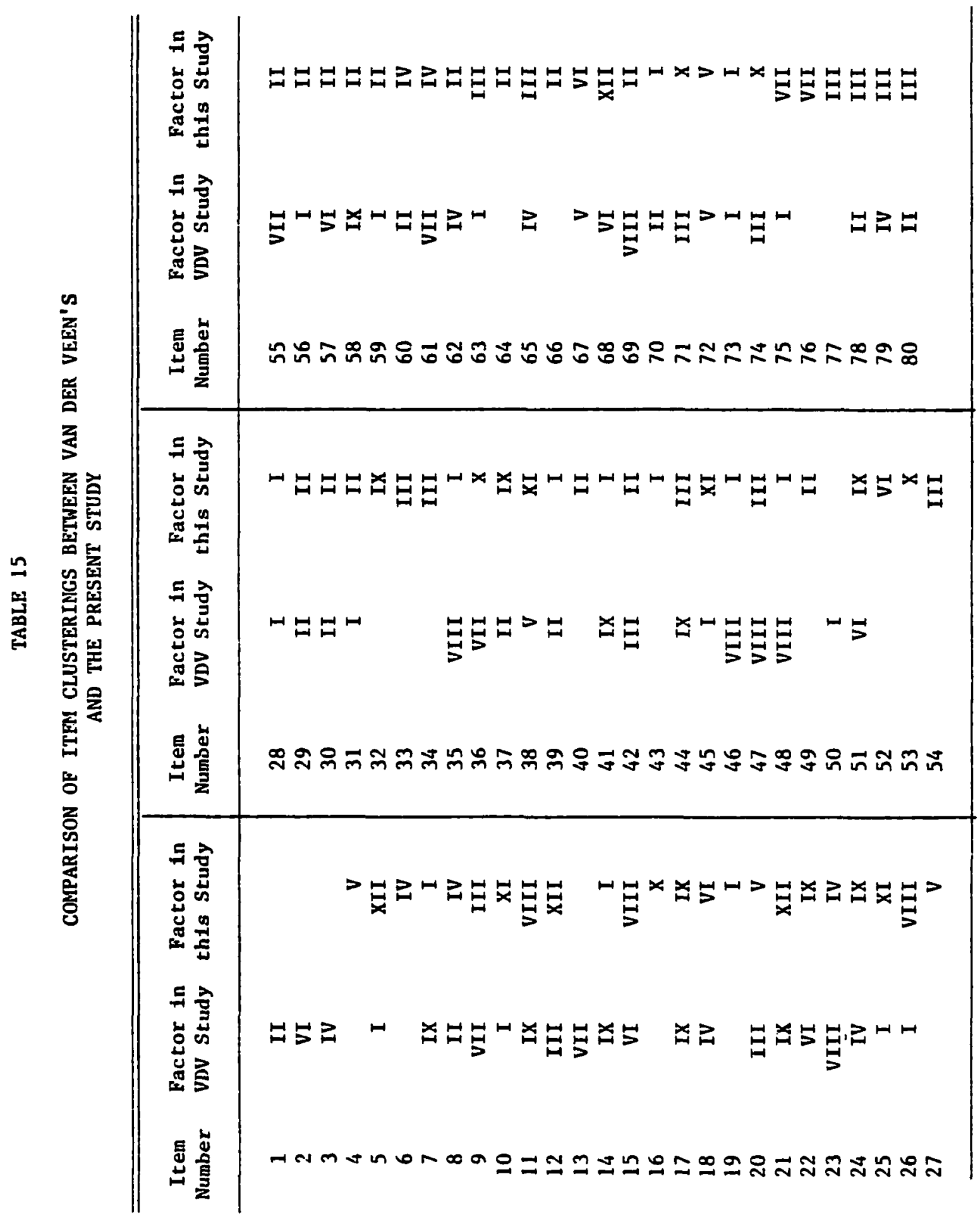


Differences in Ideal Family Concept

According to Group Means on

Total Score

Table 16 shows the group means on each variable, using

total scores on the elghty-item test. The t-test was used to compare

the means between classifications within each of the variables:

(1) Grade in School, (2) Church Membership, (3) Sex, (4) Race, and

(5) Parental Number. Each of these variables had two levels of comparison.

TABLE 16

DIFFERENCES BETWEEN GROUPS WITHIN VARIABLES

USING TOTAL SCORES

\begin{tabular}{|c|c|c|c|c|}
\hline Variable & Groups & Means & df & $t$ \\
\hline Grade In School & $\begin{array}{l}\text { Ninth } \\
\text { Twelfth }\end{array}$ & $\begin{array}{l}502.56 \\
500.63\end{array}$ & 121 & .201 \\
\hline Church Membership & $\begin{array}{l}\text { SDA } \\
\text { Non-SDA }\end{array}$ & $\begin{array}{l}517.23 \\
480.66\end{array}$ & 121 & $4.049 *$ \\
\hline Sex & $\begin{array}{l}\text { Male } \\
\text { Female }\end{array}$ & $\begin{array}{l}488.89 \\
516.28\end{array}$ & 121 & $-2.750 *$ \\
\hline Race & $\begin{array}{l}\text { Whites } \\
\text { Non-Whites }\end{array}$ & $\begin{array}{l}503.75 \\
496.37\end{array}$ & 121 & .692 \\
\hline $\begin{array}{c}\text { Residential } \\
\text { Location }\end{array}$ & $\begin{array}{l}\text { Rural } \\
\text { Urban } \\
\text { Suburban }\end{array}$ & $\begin{array}{l}495.39 \\
490.74 \\
527.60\end{array}$ & & \\
\hline Parental Number & $\begin{array}{l}\text { Both Parents } \\
\text { One Parent }\end{array}$ & $\begin{array}{l}497.76 \\
498.095\end{array}$ & 98 & -.092 \\
\hline
\end{tabular}

*Note: $\mathrm{p}<.05$

Two significant differences $(p<.05)$ were found--church membership and sex. Since the means of the total scores of the 
Seventh-day Adventist adolescents were higher than those of the nonSeventh-day Adventist adolescents, it was observed that the Adventist adolescents had a more positive family concept than the non-Adventist adolescents. Similarly, female adolescents have a more positive family concept than male adolescents. Grade in School, Race, and Parental Number were not found to be significantly related to the adolescents' total family concept.

The one-way analysts of vartance was used for comparison of residential locations across three levels--rural, urban, and suburban. Table 17 summarlzes the analyses of variance in the comparison of these means. The F-ratio of 5.25 is significant. The Newman-Keul's a-posteriori test indicates that adolescents from suburban residences had a significantly more positive family concept than those from either urban or rural residences. There was no signiflcant difference between the latter two.

\section{TABLE 17}

\section{ANALYSIS OF VARIANCE OF DIFFERENCES IN IDEAL FAMILY CONCEPTS AMONG ADOLESCENTS FROM RURAL, URBAN, AND SUBURBAN RESIDENTIAL LOCATIONS}

\begin{tabular}{lrrrr}
\hline \hline Source & df & SS & MS & F \\
\hline Between Groups & 2 & 27350.77 & 13675.39 & $5.25 *$ \\
W1thin Group & 120 & 314385.08 & 2619.88 & \\
\hline Total & 121 & 341735.85 & & \\
\hline${ }_{\text {F }} .95(2,120)$ & $=3.70$ & & &
\end{tabular}


Differences in Ideal Family Concept

According to Factors

Appendix G shows the means of all the groups on all the

factors. Multivariate analysis of varlance (MANOVA) was performed on the twelve factor means for each of the independent variables and their results are outlined in table 18. A significant difference $(p<.05)$ between groups was obtained with respect to only three of the variables: (1) Church Membersip, with $F=4.08$, (2) Race, with $F=3.54$, and (3) Residential Location with $F=1.62$. The variables which did not reveal significant differences were Grade in School, Sex, and Parental Number.

TABLE 18

DIFFERENCES BETWEEN GROUPS BASED ON THE TWELVE FACTORS AS ANAIYZED BY MANOVA

\begin{tabular}{lrcc}
\hline \hline Variable & df & F-Rat1o & Critical F \\
\hline Grade in School & 12 & 1.25 & 1.845 \\
Church Membership & 110 & & \\
& 12 & $4.08 *$ & 1.845 \\
Sex & 110 & & 1.845 \\
Race & 12 & 1.60 & 1.845 \\
Residential Location & 110 & & 1.61 \\
Parental Number & 110 & $3.54 *$ & \\
& 218 & $1.62 *$ & 1.89 \\
\hline
\end{tabular}


Factors that Discriminate Between Signiflcant Variables

The three significant varlables--Church Membership, Race, and Residential Location, which yielded significant F-ratios in the multivarlate analysis of varlance--were further subjected to discriminant analysis utilizing factor scores as the bases of comparison to seek clarification of the differences between the groups.

Church membership. Table 19 shows, for ease of comparison, the group centrolds (that is, the group mean scores) of the twelve factors for Seventh-day Adventist and non-Seventhday Adventist adolescents. For the test of significance of the discriminant functions, the ch1-square was 54.02 with 12 degrees of freedom. The critical chi-square was 21.03 . Therefore, the discriminant function was significant in separating the two groups. The means of the discriminant function of the two groups were as follows: Seventh-day Adventist adolescents, .5768 and non-Seventhday Advent1st adolescents, -.7617

The standardized discriminant weights are given in table 20 . (The standardized discriminant weight was obtained by multiplying the discriminant function coefficient by the standard deviation of the corresponding varlable.) The standardized welghts enable comparisons to be made between the relative importance of the varlables in separating the groups. There were four factors that had high standardized discriminant welghts. There were attachment, compatibility, pseudoconfidence (negative), and individuality. 
TABLE 19

GROUP MEANS USED IN DISCRTMINANT ANALYSIS

BETWEEN CHURCH MEMBERSHIP

\begin{tabular}{lll}
\hline \hline & & \\
\hline & SDA & Non-SDA \\
\hline 1. Attachment & .2500 & -.3301 \\
2. Emotional Openness & .0611 & -.0806 \\
3. Compat1bility & .2354 & -.3115 \\
4. Inadequacy & -.0513 & .0677 \\
5. Individuality & .1866 & -.2464 \\
6. Interdependence & -.0681 & .0900 \\
7. Mutual Support & .0461 & -.0608 \\
8. Pseudo-confidence & -.2008 & .2652 \\
9. Frustration & .0555 & -.0733 \\
10. Communication & .0519 & -.0685 \\
11. Autonomy & .0904 & -.1193 \\
12. Democracy & .1074 & -.1418 \\
\hline
\end{tabular}

TABLE 20

DISCRIMINANT FUNCTION ANLAYSIS BETWEEN SEVENTH-DAY

ADVENTIST AND NON-SEVENTH-DAY

ADVENTIST ADOLESCENTS

\begin{tabular}{|c|c|c|}
\hline & Eactor & $\begin{array}{c}\text { Standardized } \\
\text { Discriminant } \\
\text { Weight }\end{array}$ \\
\hline $\begin{array}{l}1 . \\
2 . \\
3 . \\
4 . \\
5 . \\
6 . \\
7 . \\
8 . \\
9 . \\
10 . \\
11 . \\
12 .\end{array}$ & $\begin{array}{l}\text { Attachment } \\
\text { Emotlonal Openness } \\
\text { Compatibility } \\
\text { Inadequacy } \\
\text { Individuality } \\
\text { Interdependence } \\
\text { Mutual Support } \\
\text { Pseudo-confidence } \\
\text { Frustration } \\
\text { Communication } \\
\text { Autonomy } \\
\text { Democracy }\end{array}$ & $\begin{array}{r}.5979 \\
.1521 \\
.5669 \\
-.1279 \\
.4551 \\
-.1696 \\
.1149 \\
-.4880 \\
.1383 \\
.1293 \\
.2245 \\
.2662\end{array}$ \\
\hline
\end{tabular}

Reproduced with permission of the copyright owner. Further reproduction prohibited without permission. 
Seventh-day Adventist adolescents tended to value attachment, compatibility, and Individuality more highly than the nonSeventh-day Adventist adolescents in their conceptualization of their Ideal families. The non-Seventh-day Adventist adolescents saw more pseudo-confidence in their ideal family than did the Seventh-day Adventist adolescents.

Race. Table 21 shows the group means on factor scores for white and non-white adolescents. The test of significance for the discriminant function ylelded a chi-square of 504.7 with 12 degrees of freedom and the critical chi-square was 21.03 showing a significance $(p<.05)$ in the separation of the whites from the non-Whites. The mean of the discriminant function for the nonwhite adolescents was 1.0228 and for the white adolescents, it was -.3993. The factors that had high standardized discriminant welghts were individuality, emotional openness (negative), compatiblitity, and democracy (see Table 22). These findings Indicate that non-white adolescents tended to view the ideal family as more individualistic, with less emotional openness, having more compatiblilty, and being more democratic than the white adolescents.

Residential location. The group means on the factor scores for rural, urban, and suburban adolescents are shown in table 23. The test of significance revealed a chi-square of 43.56 in the first discriminant function with 24 degrees of freedom and the critical chi-square was 36.42 . There was a significant $(p<.05)$ discriminant function separating the rural and the urban and suburban adolescents. The means of the discriminant function were 
TABLE 21

GROUP MEANS USED IN DISCRIMINANT ANALYSIS BETWEEN RACE

\begin{tabular}{lrr}
\hline \multicolumn{1}{c}{ Factor } & White & Non-White \\
\hline 1. Attachment & -.0753 & .1825 \\
2. Emotional Openness & .1309 & -.3415 \\
3. Compatibility & -.1213 & .3084 \\
4. Inadequacy & -.0275 & .0979 \\
5. Individuality & -.1664 & .3945 \\
6. Interdependence & .0728 & -.2216 \\
7. Mutual Support & .0315 & -.1083 \\
8. Pseudo-confidence & -.0484 & .1414 \\
9. Frustration & -.0967 & .2503 \\
10. Communication & -.1142 & .2617 \\
11. Autonomy & .0869 & -.1773 \\
12. Democracy & -.1002 & .3000 \\
\hline
\end{tabular}

TABLE 22

DISCRIMINANT FUNCTION ANALYSIS BETWEEN WHITE AND NON-WHITE ADOLESCENTS

$\begin{array}{cc}\text { Sactor } & \begin{array}{c}\text { Standardized } \\ \text { Discriminant } \\ \text { Weight }\end{array} \\ \end{array}$

1. Attachment

2. Emotional Openness

3. Compatibility

4. Inadequacy

5. Individuality

6. Interdependence

7. Mutual Support

$-.4596$

.4179

.1320

.5287

$-.2977$

8. Pseudo-confidence

$-.1462$

.1926

.3410

.3579

10. Communication

11. Autonomy

12. Democracy

$-.2452$

.3982

Total variation $=50.47$ Critical ch1-square $=21.03$

with 12 d.f., and $p<.05$ 
TABLE 23

GROUP MEANS USED IN DISCRIMINANT ANALYSIS AMONG RESIDENTIAL LOCATIONS

\begin{tabular}{|c|c|c|c|c|}
\hline & Factor & Rural & Urban & Suburban \\
\hline $\begin{array}{l}1 . \\
2 . \\
3 . \\
4 . \\
5 . \\
6 . \\
7 . \\
8 . \\
9 . \\
10 . \\
11 . \\
12 .\end{array}$ & $\begin{array}{l}\text { Attachment } \\
\text { Emotional Openness } \\
\text { Compatibility } \\
\text { Inadequacy } \\
\text { Individuality } \\
\text { Interdependence } \\
\text { Mutual Support } \\
\text { Pseudo-confidence } \\
\text { Frustration } \\
\text { Communication } \\
\text { Autonomy } \\
\text { Democracy }\end{array}$ & $\begin{array}{r}-.1087 \\
-.0331 \\
-.1915 \\
.0515 \\
-.1079 \\
-.0228 \\
-.0541 \\
.0061 \\
-.1384 \\
-.2534 \\
.2156 \\
-.1251\end{array}$ & $\begin{array}{r}.0538 \\
-.2348 \\
-.0005 \\
-.0003 \\
.1307 \\
-.0588 \\
-.0383 \\
.0508 \\
.0876 \\
.3726 \\
-.3143 \\
.1650\end{array}$ & $\begin{array}{r}.0988 \\
.3985 \\
.3136 \\
-.0837 \\
-.0154 \\
.1236 \\
.1446 \\
-.0845 \\
.0976 \\
-.1326 \\
.1089 \\
-.0376\end{array}$ \\
\hline
\end{tabular}

TABLE 24

DISCRIMINANT FUNCTION ANALYSIS AMONG RURAL, URBAN, AND SUBURBAN RESIDENTIAL LOCATIONS

\begin{tabular}{lccc}
\hline \multicolumn{1}{c}{ Factor } & Standardized & \multicolumn{2}{c}{ Discriminant Welght } \\
First & Second \\
& & & \\
\hline 1. Attachment & .1102 & .2596 \\
2. Emotional Openness & -.4062 & .5682 \\
3. Compatibility & .0229 & .6383 \\
4. Inadequacy & -.0070 & -.1740 \\
5. Individuality & .2479 & .1022 \\
6. Interdependence & -.1029 & .1957 \\
7. Mutual Support & -.0620 & .2600 \\
8. Pseudo-confidence & .0907 &.- .1230 \\
9. Frustration & .1742 & .2912 \\
10. Comunication & .6748 & -.1043 \\
11. Autonomy & -.5765 & .0952 \\
12. Democracy & .3105 & .0912 \\
& & \\
\hline Total varlation (chi-squares) & 43.56 & 13.63 \\
Critical chi-squares & 36.42 & 19.68 \\
Degrees of freedom & 24 & 11 \\
Probability & $<.05$ & $>.05$
\end{tabular}


.6603 for urban adolescents, -.3312 Eor suburban adolescents, and -. 3901 for rural adolescents. The first order factors with high. standardized discriminant weights generated according to residential locations are listed in order of importance: greater communication, less autonomy, less emotional openness, and more democracy (see table 24). For the second discriminant function, the test of signiflcance was not significant in separating the groups.

\section{Summary of the Significant Discriminant} Function Analyses

The factors that had the highest standardized discriminant weights when comparing the three significant independent variables are summarized in table 25. Four factors stand out in their ability to discriminate between groups.

1. Emotional Openness. This factor serves to discriminate between groups according to race and residential location.

2. Compatibility. This factor serves to separate adolescents according to church membership and race.

3. Individuality. This factor separates adolescent groups according to church membership and race.

4. Democracy. This factor disrriminates between adolescents according to race and residential location 
TABLE 25

SUMMARY OF SIGNIFICANT DISCRIMINANT FUNCTION COEFFICIENTS

\begin{tabular}{|c|c|c|c|c|}
\hline & Eactor & $\begin{array}{l}\text { Church } \\
\text { Membership }\end{array}$ & Race & $\begin{array}{l}\text { Residential } \\
\text { Location }\end{array}$ \\
\hline 1. & Attachment & .5979 & & \\
\hline 2. & Emotional Openness & & -.4596 & -.4062 \\
\hline 3. & Compatibility & .5669 & .4179 & \\
\hline 4. & Inadequacy & & & \\
\hline 5. & Individuality & .4551 & .5287 & \\
\hline 6. & Interdependence & & & \\
\hline 7. & Mutual Support & & & \\
\hline 8. & Pseudo-confidence & -.4880 & & \\
\hline 9. & Frustration & & & \\
\hline 10. & Communication & & & $.6748^{\circ}$ \\
\hline 11. & Autonomy & & & -.5765 \\
\hline 12. & Democracy & & .3982 & .3105 \\
\hline \multicolumn{2}{|c|}{ Total Varlation (chl-squares) } & 54.02 & 50.47 & 43.65 \\
\hline \multicolumn{2}{|c|}{ Critical chisquares } & 21.03 & 21.03 & 36.42 \\
\hline \multicolumn{2}{|c|}{ Degrees of freedom } & 12 & 12 & 24 \\
\hline \multicolumn{2}{|c|}{ Probability } & $<.05$ & $<.05$ & $<.05$ \\
\hline
\end{tabular}


CHAPTER V

SUMMARY, CONCLUSIONS, AND IMPLICATIONS

\begin{abstract}
Summary
The purpose of this study was to Identify the ideal family concepts held by 123 adolescents from ninth and twelfth grades in thirteen selected high schools in Illinois, Indiana, and Michigan. Answers to the following three questions were sought:
\end{abstract}

1. Can the adolescent's concept of the Ideal famtly be described in terms of a number of basic factors?

2. If there are basic factors, how do they compare with those identified by van der Veen (1971) in his study of disturbed adolescents?

3. Are there differences in the ideal family concept when adolescents are compared according to (a) grade in school, (b) church membership, (c) sex, (d) race, (e) residential location, and (f) parental number?

Three major approaches to the study of the family were reviewed in detall from the perspective of socialization and the nuclear family. The structural-functional approach emphasizes the Importance of structure or form, and how function or purpose depends largely upon how the famlly has been set up in the first 60 
place. The interactional and situational approach concentrates on the roles and patterns of interaction that take place between different individuals within the familles as they play different roles. The third approach--the developmental theory--is the oldest of all and directs its attention to the longitudinal career of the family system. Through microanalysis, it attempts to account for changes in patterns of interaction over the family life span.

The literature review further examined how parent-adolescent relations are developed. It was found that soctalization, conflict, struggles for adolescent autonomy, and other parent-child relations all contribute to the adolescent concept of the family. Other factors that appear to have some influence on the formation of the family concept are home relationships, school, family background, and emotional stability of the parents.

This study employed the descriptive method involving factor analysis, the t-test of signtficance between means, one-way analysis of varlance, multivariate analysis of variance, and discriminant analysis. Seven hypotheses were advanced for testing. A panel of experts helped determine the descriptors for the twelve dimensions of the Ideal family concept.

The Family Unit Inventory (FUI) developed by van der Veen (1969) was used to measure the adolescents' viewpoints on different aspects of the ideal family. The instrument was first administered in a pilot study to 20 twelfth graders and 21 ninth graders in the Andrews University Academy to test the data-gathering and data-analysis procedures. The FUI was later administered to 
approximately ten randomly chosen students from each of the thirteen selected high schools. The data were coded, entered, tabulated and analyzed.

Twelve independent but psychologically meaningful factors surfaced after rotation of different numbers of factors and accounted for 58 per cent of the total variance. The twelve factors were Identified as follows: (1) attachment, (2) emotional openness, (3) compatibility, (4) inadequacy, (5) Individuality, (6) interdependence, (7) mutual support, (8) pseudo-confidence, (9) frustration, (10) communication, (11) autonomy, and (12) democracy. When compared with the findings of van der Veen's work, it was found that the items clustered in different ways to form factors. It was not expected that the two sets of factors would have identical item loadings because of the differences in the populations involved in the two studies.

The t-test for significance between means revealed that the Ideal family concept of Seventh-day Adventist adolescents was significantly more positive than that of non-Seventh-day Adventist adolescents, and that the family concept of female adolescents was significantly more positive than that of male adolescents. Grade in School, Race, and Parental Number were not found to be significantly related to, the ideal family concept. Using the one-way analysis of varlance and Newman-Keul's test on the scores of the adolescents with homes in rural, urban, and suburban locations, it was found that the adolescents from suburban homes had a significantly more positive ideal family 
concept than those from urban or rural homes; and that there was no difference between the latter two.

The multivariate analysis of variance using the twelve factor scores isolated by factor analysis, revealed that the subjects differed in their ideal family concept when they were compared according to church membership, race, and residential location. Grade in school, sex, and parental number were not found to be significantly related to the factor centroids.

When discriminant analysis was used to further analyze the three significant vartables uncovered by the multivariate analysis of variance, It was found that the factors emotional openness, compatibility, and individuality were most sensitive in discriminating between the various subgroups.

\section{Conclusions}

Seven hypothesss were advanced for testing in this study. Conclustons were drawn concerning each individual statement of hypotheses.

Hypothesis 1. The concept of the 1deal family as held by adolescents can be described in terms of a number of basic factors. This hypothesis was supported. The study showed that the adolescent's concept of the ideal family conld be described in terms of twelve identifiable independent dimensions.

Hypothesis 2(a). There is no significant difference between the means of the Ideal family concept scores of adolescents in grades nine and twelve. The comparison of the overall means by the 
t-test showed no significant difference between the two groups. The data failed to reject the null hypothesis at the .05 level of confidence.

Hypothesis 2(b). There is no significant difference between the centroids of the Ideal family factor scores of adolescents in grades nine and twelve. The comparison of factor score centroids by multivarlate analysis of varlance showed no significant difference between the two groups. The data failed to refect the null hypotheses at the .05 level of confidence.

Hypothesis $3(a)$. There is no significant difference between the means of the ideal family concept scores of Seventh-day Adventist and non-Seventh-day Adventist adolescents. The t-test showed a significant difference with the Adventist adolescents having a more positive family concept than non-Adventist adolescents. The null hypothesis was rejected at the .05 level of confidence.
Hypothesis $3(\mathrm{~b})$. There is no significant difference between the centrolds of the ideal family concept factor scores of Seventh-day Adventist and non-Seventh-day Adventist adolescents. The multivariate analysis of varlance indicated a significant dif- ference $(F=4.08)$ with Seventh-day Adventist adolescents having a more positive family concept than non-Adventist adolescents. The discriminant analysis ylelded a significant chi-square of 54.02. This showed that the Seventh-day Adventist adolescents view attachment, compatibılity, and individualfty more positively than 
non-Seventh-day Adventist adolescents. The null hypothesis was rejected at the .05 level of confidence.

Hypothesis $4(\mathrm{a})$. There is no significant difference between the means of the ideal family concept scores of male and female adolescents. The t-test showed a significant difference between the two groups. Female adolescents have more positive famlly concepts than male adolescents. The null hypothesis wac rejected at the .05 level of confidence.

Hypothesis 4(b). There is no significant difference between the centroids of the Ideal family concept factor scores of male and female adolescents. The multivartate analysis of varlance showed no significant difference between the two groups. The data, therefore, failed to reject the null hypothesis at the .05 level of confidence.

Hypothesis 5(a). There is no significant difference between the means of the Ideal family concept scores of white and non-white adolescents. The t-test showed no significant difference hetween the two groups. The data falled to reject the null hypothesis at the .05 level of confidence.

\section{Hypothesis $5(\mathrm{~b})$. There is no significant difference} between the centroids of the Ideal family concept factor scores of white and non-white adolescents. The multivariate analysis of varfance showed a significant difference between the two groups. Whites had a very different family concept from the non-whites. The discriminant analysis yielded a significant chi-square of 50.47. This analysis showed that white adolescents perceived the 
Ideal family as being less individualistic, having more emotional openness, less compatibility, and being less democratic than the nonwhite adolescents. The null hypothesis was rejected at the .05 level of confidence.

Hypothesis 6(a). There is no signiflcant difference among the means of the 1 deal family concept scores of rural, urban, and suburban adolescents. Data from the one-way analysis of variance showed a significant difference $(F=5.25)$. Adolescents from suburban residences have a significantly more positive family concept than those from either urban or rural residences. The null hypothesis was refected at the .05 level of confidence. Hypothesis $6(\mathrm{~b})$. There is no significant difference among the centroids of the ideal family concept factor scores of rural, urban, and suburban adolescents. The multivarlate analysis of variance revealed a significant difference $(F=1.62)$, and the discriminant analysis yielded a significant discriminant function with a chi-square of 43.56. Factors discriminating the groups from each other were communication, democracy, and emotional openness. The null hypothesis was rejected at the .05 level of confidence. Hypothesis 7(a). There is no significant difference between the means of the Ideal family concept scores of adolescents from two-parent and one-parent families. The t-test showed no significant difference between the two groups. The evidence failed to reject the null hypothesis at the .051 level of confidence. 
Eypothesis $7(b)$. There is no significant difference between the centroids of the ideal family concept factor scores of adolescents from two-parent and one-parent families. The comparison of factor score means by a multivarlate analysis of varlance showed no significant difference between the two groups. The evidence failed to reject the null hypothesis at the .05 level of confidence.

\section{Discussions on Findings}

The present study has Identified twelve dimensions of the Ideal family concept held by adolescents. The overall ideal family concept of the adolescents and their concept with respect to the twelve factors were studied in relation to the independent variables: grade in school, church membership, sex, race, residential location, and parental number.

Influences of church membership. The 1deal family concept of the adolescents were significantly related to church membership. Among the Seventh-day Adventist adolescents, attachment, compatibility, and Individuality were perceived as more important dimensions in the Ideal family, whereas the pseudo-confidence dimension figured more highly in the ideal family concept of nonSeventh-day Adventist adolescents.

Influences of grade level in school. Grade level did not affect the adolescents' concept of the family. Could it be that there was no difference between the freshmen and senior curricula for family life aducation? Could it be that in Seventh-day Adventist academies family-life education was built into the total 
curriculum but not in the public school, or vice versa? Or was it because the family-life-education concepts had been taught all through the grades and ignored on the secondary school level, so that no real impact was made between the first and fourth years of high school? Could it be that family-life education had not been taught at all?

\section{Influences of race. With respect to this independent}

varlable, the whites tended to view emotional openness in the family as more Important than did the non-whites, but compatibility, individuality, and democracy are less important. Is this because the whites are more realistic in their ideal family concept? The whites' 1deas of what works and what does not work may not be seen by non-whites. It Implies that non-whites prefer to have families that are more compatible, individualistic, and democratic than do the whites'.

Influences of residential location. Proceeding from urban to suburban to rural homes, the Ideal family concept becomes less communicative, more autonomous, more emotionally open, and less democratic.

\section{Implications}

The study was undertaken to discover and describe the dimensions of the adolescent concept of the ideal family. The findings indicate definite directions and further studies that need to be done. 
For the Seventh-day Adventist Church

In the process of identifying some of the basic dimensions of the adolescent concept of the Ideal family, this study has underscored the role of church membership. Since the findings showed that adolescents who are members of the Seventh-day Adventist Church view the famlly differently, it is recommended that:

1. the Seventh-day Advent1st Church develop and establish programs for adolescents to enrich family living, based on the Church's philosophy of the family.

2. the Seventh-day Adventist Church explore the possibilities of developing educational materials for parenthood and familylife education for adolescents.

For Educators and Psychologists

3. The twelve factors identified could serve as the basis for curricula in Family-Life Education. It is therefore recommended that they be incorporated into existing family-iffereducation curricula in the Adventist academies. Also to be noted is that the approaches for boys should differ from those for girls when planning for and constructing high school curriculum for familyIife education.

4. During the high school years, the development of the family concept is seemingly not affected by the school. This suggests that family concepts have been taught or caught in the early years in the elementary school. Therefore the building of right famlly concepts begins long before the adolescent's freshman 
year in high school. Elementary schools can therefore play a very important part or role in the prevention of family breakdown. On the positive side, there is no change in ideal family concept even though the adolescents are growing away from the family.

For Further Theoretical Studies

5. It is recommended that the twelve factors empirically isolated In this study be studled with other samples to see if they are reasonably stable and then be developed into a standardized instrument for assessment and description of family concept development among Seventh-day Adventist adolescents. Norms should be developed for different groups, sexes, races, and residential locations. It is further recommended that the twelve factors be used as a theoretical framework for famlly studies among Seventh-day Adventists, so that adolescents will adopt views that would benefit them in the perception of the family.

6. There were items found to have no significant loadings. It is recommended that this study be replicated to verffy the usefulness of these items in van der Veen's instrument.

7. A study using the same procedures among parents of adolescents is also recommended. A comparison made between the Ideal family concepts of the adolescents and their parents could be useful in deriving an index for the generation gap in families.

8. A correlation study on the actual and ideal family concepts of normal adolescents is also recoumended. 
9. A study Involving three generations--not living under one roof-might reveal directions and insights on how to narrow the generation gap. The effects of inputs from grandparents in the development of the family concept could also be assessed in such a study.

10. In the present study the sample generated twelve dimensions in the ideal family concept. It is recommended that further study be done to identify the factor structures of each of the subgroups-males, females, whites, non-whites, suburbanites, urbanites, Seventh-day Adventists, non-Seventh-day Adventists, and similar groups. 
APPENDIX A

THE FAMILY UNIT INVENTORY

Reproduced with permission of the copyright owner. Further reproduction prohibited without permission. 


\section{Family Unit Inventory}

(C) Ferdinand van der Veen, Ph. D., 1969. Family Research Program, Institute for Juvenile Research, Chicago, Illinois. 


\section{Instructions}

For each of the items, circle the number that shows how true the item is for your family as you would ideally like it to be. It does not matter what your family is actually like, only what you most want it to be like.

You can circle any number from "0" to "8". At one end, "0" means the item is completely false for your ideal family. At the other end, "g" means it is very true for your ideal family.

Circle one number to the right of each item. Please make no other marks on the paper.

FOR EXAMPLE, if you would want your family to ideally be somewhat active, you would mark the sample item in this way:

SAMPLE:

least Ideal Family

most like like

We are an active family.

$\begin{array}{llllllllll}0 & 1 & 2 & 3 & 4 & 5 & (6) & 7 & 8\end{array}$

If you would strongly like your ideal family to be very active, you would nave circled the " 8 ". If you did not want it to be eitner active or inactive, you would have circled the "4". If you did not want it to be active at all, you :yould have circled the " 0 ".

Use the various numbers in all of the positions, whichever best fits your answer from "0", completely false, to " $8 "$ ", very true.

Please ask any questions if it is not clear what to do. Fill in the information about yourself at the bottom of this page, and go ahead and answer each item according to how well it fits your family as you would most like it to be. Be as careful and accurate as you can and answer all the items. THANK YOU.

Name of school [1] [2] Today's Date

Grade [1][2] Relfgion: [1] [2]

Sex: [1] [2] Race: [ ] white [ ] Black [ ] chicano [] others..

My home is in a [] rural-farm area [ ] urban-city area [ ] suburban area. I am living with [ ] both parents [ ] mother only [ ] father only [ ] relatives [ ] foster parents [] other students in a school dormitory. 


\section{FAMILY UNIT INVENTORY}

1. We like to do new and different things.

2. We can usually depend on each other.

3. We have a number of close friends.

4. We often do not agree on important matters.

5. Each of us tries to be the kind of person the others will like.

6. Good manners and proper behavior are very important to us.

7. We feel secure (safe) when we are ivith each other.

S. We want help with our problems.

9. We do many things together.

10. Each of us wants to tell the others what to do.

11. There are serious differences in our beliefs about what is right and important.

12. We feel free to express any thought or feeling to each other.

13. Our home is the center of our activities.

14. We are an affectionate family (show our love for each other).

15. The difficulties that we have in the family are not our fault.

$\begin{array}{cl}\begin{array}{c}\text { least } \\ \text { like }\end{array} & \begin{array}{l}\text { most } \\ \text { like }\end{array}\end{array}$

$\begin{array}{lllllllll}0 & 1 & 2 & 3 & 4 & 5 & 6 & 7 & 8\end{array}$

$\begin{array}{lllllllll}0 & 1 & 2 & 3 & 4 & 5 & 6 & 7 & 8\end{array}$

$\begin{array}{lllllllll}0 & 1 & 2 & 3 & 4 & 5 & 6 & 7 & 8\end{array}$

$\begin{array}{lllllllll}0 & 1 & 2 & 3 & 4 & 5 & 6 & 7 & 8\end{array}$

$\begin{array}{lllllllll}0 & 1 & 2 & 3 & 4 & 5 & 6 & 7 & 3\end{array}$

\section{]}


16. Little problems often become big ones for us.

$\begin{gathered}\text { least } \\ \text { like }\end{gathered}$
IDEAL FAMILY most
like

17. We do not understand each other.

$\begin{array}{lllllllll}0 & 1 & 2 & 3 & 4 & 5 & 6 & 7 & 8\end{array}$

$\begin{array}{lllllllll}0 & 1 & 2 & 3 & 4 & 5 & 6 & 7 & 8\end{array}$

[17]

18. We get along very well in the community.

$\begin{array}{lllllllll}0 & 1 & 2 & 3 & 4 & 5 & 6 & 7 & 8\end{array}$

19. We often praise or compliment each other.

$\begin{array}{lllllllll}0 & 1 & 2 & 3 & 4 & 5 & 6 & 7 & 8\end{array}$

20. We avoid talking about sexual matters.

$\begin{array}{lllllllll}0 & 1 & 2 & 3 & 4 & 5 & 6 & 7 & 8\end{array}$

21. We get along much better with persons outside the family than with each other.

$\begin{array}{lllllllll}0 & 1 & 2 & 3 & 4 & 5 & 6 & 7 & 8\end{array}$

22. If we had more money most of our present problems would be gone.

$\begin{array}{lllllllll}0 & 1 & 2 & 3 & 4 & 5 & 6 & 7 & 8\end{array}$

23. We are proud of our family.

$\begin{array}{lllllllll}0 & 1 & 2 & 3 & 4 & 5 & 6 & 7 & 8\end{array}$

24. We do not like each other's friends.

$\begin{array}{lllllllll}0 & 1 & 2 & 3 & 4 & 5 & 6 & 7 & 8\end{array}$

25. There a re many conflicts (disagreements) in our family

$\begin{array}{lllllllll}0 & 1 & 2 & 3 & 4 & 5 & 6 & 7 & 8\end{array}$

26. We are usually calm and relaxed when we are together.

$\begin{array}{lllllllll}0 & 1 & 2 & 3 & 4 & 5 & 6 & 7 & 8\end{array}$

27. We are not a talkative family.

$\begin{array}{lllllllll}0 & 1 & 2 & 3 & 4 & 5 & 6 & 7 & 8\end{array}$

28. We respect each other's privacy.

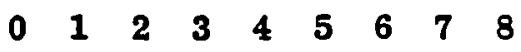

29. Accomplishing (actually getting done) what we want to do seems to be difficult for us.

$\begin{array}{lllllllll}0 & 1 & 2 & 3 & 4 & 5 & 6 & 7 & 8\end{array}$

30. We tend to worry about many things.

$\begin{array}{lllllllll}0 & 1 & 2 & 3 & 4 & 5 & 6 & 7 & 8\end{array}$

31. We often upset each other without meaning to. $0 \begin{array}{lllllllll}0 & 1 & 2 & 3 & 4 & 5 & 6 & 7 & 8\end{array}$

32. Nothing exciting ever seems to happen to us. $\quad \begin{array}{lllllllll}0 & 1 & 2 & 3 & 4 & 5 & 6 & 7 & 8\end{array}$

33. We are a religious family.

$\begin{array}{lllllllll}0 & 1 & 2 & 3 & 4 & 5 & 6 & 7 & 8\end{array}$

34. We are continually getting to know each better.

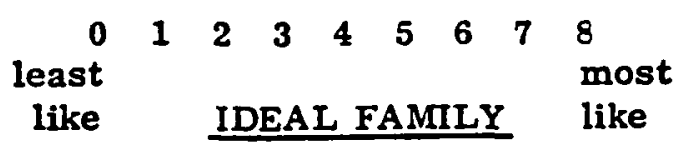

CONTINUE TO NEXT PAGE 
35. We need each other.

36. We do not spend enough time together.

37. We do not understand what is causing our difficulties.

38. Success and reputation are very important to us.

39. We encourage each other to develop in his or ber own individual way.

40. We a re ashamed of some things about our family.

41. We have warm, close relationships with each other.

42. There are some things which we avoid talking about.

43. Together we can overcome almost any difficulty.

44. We really do trust and confide in each other

45. We make many demands on each other.

46. We take care of each other.

47. Our activities together are usually planned and organized.

48. The family has always been very important to us.

49. It is hard for us to please each other.

50. We are considerate of each other.

51. We can stand up for our rights if necessary. $\begin{array}{lllllllll}0 & 1 & 2 & 3 & 4 & 5 & 6 & 7 & 8\end{array}$

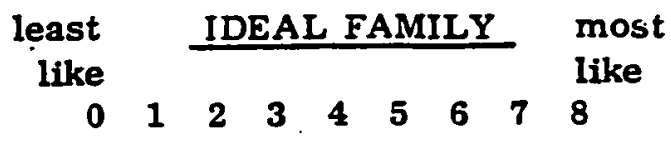

$\begin{array}{lllllllll}0 & 1 & 2 & 3 & 4 & 5 & 6 & 7 & 8\end{array}$

$\begin{array}{lllllllll}0 & 1 & 2 & 3 & 4 & 5 & 6 & 7 & 8\end{array}$

$\begin{array}{lllllllll}0 & 1 & 2 & 3 & 4 & 5 & 6 & 7 & 8\end{array}$

$\begin{array}{lllllllll}0 & 1 & 2 & 3 & 4 & 5 & 6 & 7 & 8\end{array}$

$\begin{array}{lllllllll}0 & 1 & 2 & 3 & 4 & 5 & 6 & 7 & 8\end{array}$

$\begin{array}{lllllllll}0 & 1 & 2 & 3 & 4 & 5 & 6 & 7 & 8\end{array}$

$\begin{array}{lllllllll}0 & 1 & 2 & 3 & 4 & 5 & 6 & 7 & 8\end{array}$

$\begin{array}{lllllllll}0 & 1 & 2 & 3 & 4 & 5 & 6 & 7 & 8\end{array}$

$\begin{array}{lllllllll}0 & 1 & 2 & 3 & 4 & 5 & 6 & 7 & 8\end{array}$

$\begin{array}{lllllllll}0 & 1 & 2 & 3 & 4 & 5 & 6 & 7 & 8\end{array}$

$\begin{array}{lllllllll}0 & 1 & 2 & 3 & 4 & 5 & 6 & 7 & 8\end{array}$

$\begin{array}{lllllllll}0 & 1 & 2 & 3 & 4 & 5 & 6 & 7 & 8\end{array}$

$\begin{array}{lllllllll}0 & 1 & 2 & 3 & 4 & 5 & 6 & 7 & 8\end{array}$

$\begin{array}{lllllllll}0 & 1 & 2 & 3 & 4 & 5 & 6 & 7 & 8\end{array}$

$\begin{array}{lllllllll}0 & 1 & 2 & 3 & 4 & 5 & 6 & 7 & 8\end{array}$ least

like 


$$
\begin{array}{ll}
\text { least IDEAL FAMILY most } \\
\text { like like }
\end{array}
$$

52. We are all responsible for family problems. $\quad \begin{array}{lllllllll}0 & 1 & 2 & 3 & 4 & 5 & 6 & 7 & 8\end{array}$

53. There is not enough discipline in our family. $\begin{array}{llllllllll}0 & 1 & 2 & 3 & 4 & 5 & 6 & 7 & 8\end{array}$

54. We have very good time together.

$\begin{array}{lllllllll}0 & 1 & 2 & 3 & 4 & 5 & 6 & 7 & 8\end{array}$

55. We are sometimes frightened of each other. $\quad \begin{array}{lllllllll}0 & 1 & 2 & 3 & 4 & 5 & 6 & 7 & 8\end{array}$

56. We often become angre at each other.

$\begin{array}{lllllllll}0 & 1 & 2 & 3 & 4 & 5 & 6 & 7 & 8\end{array}$

57. We live largely by other people's standards and values (what is right and important).

$\begin{array}{lllllllll}0 & 1 & 2 & 3 & 4 & 5 & 6 & 7 & 8\end{array}$

58. We are not as happy together as we might be. $\quad \begin{array}{lllllllll}0 & 1 & 2 & 3 & 4 & 5 & 6 & 7 & 8\end{array}$

59. We are critical of each other.

$\begin{array}{lllllllll}0 & 1 & 2 & 3 & 4 & 5 & 6 & 7 & 8\end{array}$

60. We are satisfied with the weay in which we now live.

$\begin{array}{lllllllll}0 & 1 & 2 & 3 & 4 & 5 & 6 & 7 & 8\end{array}$

61. Usually each of us goes his own separate way. $\begin{array}{llllllllll}0 & 1 & 2 & 3 & 4 & 5 & 6 & 7 & 8\end{array}$

62. We resent each other's outside activities. $\quad \begin{array}{lllllllll}0 & 1 & 2 & 3 & 4 & 5 & 6 & 7 & 8\end{array}$

63. We have respect for each other's feelings and opinions even when we differ strongly.

$$
\begin{array}{lllllllll}
0 & 1 & 2 & 3 & 4 & 5 & 6 & 7 & 8
\end{array}
$$

64. We sometimes wish we could be an entirely different family.

$\begin{array}{lllllllll}0 & 1 & 2 & 3 & 4 & 5 & 6 & 7 & 8\end{array}$

65. We are sociable and really enjoy being with people.

$\begin{array}{lllllllll}0 & 1 & 2 & 3 & 4 & 5 & 6 & 7 & 8\end{array}$

66. We are a disorganized (mixed up) family. $\quad \begin{array}{lllllllll}0 & 1 & 2 & 3 & 4 & 5 & 6 & 7 & 8\end{array}$

67. It is important to us to know how we appear to others.

$\begin{array}{lllllllll}0 & 1 & 2 & 3 & 4 & 5 & 6 & 7 & 8\end{array}$

68. Our decisions are not our own, but are

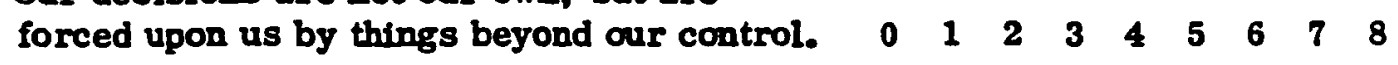

69. We have little fondness for each other.

$\begin{array}{rllllllll}0 & 1 & 2 & 3 & 4 & 5 & 6 & 7 & 8 \\ \begin{aligned} \text { least } \\ \text { like }\end{aligned} & & \text { IDEAL } & \text { FAMILY } & \text { like }\end{array}$

\section{CONTINUE TO NEXT PAGE}


70. We are a strong, competent (able) family.

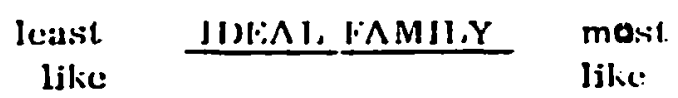

71. We avoid telling each other our real feclings.

$\begin{array}{lllllllll}0 & 1 & 2 & : & 1 & 5 & 6 & 7 & 4\end{array}$

72. We are not satisfled with anything short of perfection.

$$
\begin{array}{lllllllll}
0 & 1 & 2 & 3 & 4 & 5 & 6 & 7 & 8
\end{array}
$$

73. We forgive each other easily.

74. We are usually somewhat reserved with each other.

75. We hardly ever hurt each other's feelings.

$\begin{array}{lllllllll}0 & 1 & 2 & 3 & 4 & 5 & 6 & 7 & 8\end{array}$

76. We like the same things.

$\begin{array}{lllllllll}0 & 1 & 2 & 3 & 4 & 5 & 6 & 7 & 8\end{array}$

77. We usually reach decisions by talking it over and some give and take.

$\begin{array}{lllllllll}0 & 1 & 2 & 3 & 4 & 5 & 6 & 7 & 8\end{array}$

78. We can adfust well to new situations.

$\begin{array}{lllllllll}0 & 1 & 2 & 3 & 4 & 5 & 6 & 7 & 8\end{array}$

79. We are liked by most people who know us

$\begin{array}{lllllllll}0 & 1 & 2 & 3 & 4 & 5 & 6 & 7 & 8\end{array}$

80. We are full of life and good spirits.

$\begin{array}{lllllllll}0 & 1 & 2 & 3 & 4 & 5 & 6 & 7 & 8\end{array}$ 


\section{APPENDIX B \\ FAMILY CONCEPT TEST--POSITIVE AND NEGATIVE ITEMS}

Reproduced with permission of the copyright owner. Further reproduction prohibited without permission. 


\section{APPENDIX B}

\section{FAMILY CONCEPT TEST--POSITIVE AND NEGATIVE ITEMS}

1. We like to do new and different things.

2. We usually can depend on each other.

3. We have a number of close friends.

4. We often do not agree on important matters.

5. Each of us tries to be the kind of person the others will like.

6. Good manners and proper behavior are very 1mortant to us.

7. We feel secure when we are with each other.

8. We want help with our problems.

9. We do many things together.

-10. Each of us wants to tell the others what to do.

-11. There are serious differences in our standards and values.

12. We feel free to express any thought or feeling to each other.

13. Our home is the center of our activities.

14. We are an affectionate famfly.

-15. It is not our fault that we are having difficulties.

-16. Itttle problems of ten become big ones for us.

-17. We do not understand each other.

18. We get along very well in the community.

19. We often praise or compliment each other.

-20. We do not talk about sex.

-21. We get along much better with persons outglde the family than with each other.

22. If we had more money most of our present problems would be gone.

23. We are proud of our family.

-24. We do nct like each other's friends.

-25. There are many conflicts in our family.

26. We are usually calm and relaxed when we are together.

27. We are not a talkative family.

28. We respect each other's privacy.

-29. Accomplishing what we want to do seems to be difficult for us.

-30. We tend to worry about many things.

31. We often upset each other without intending $1 t$.

32. Nothing exciting ever seems to happen to us.

33. We are a deeply religlous family.

34. We are continually getting to know each other better.

35. We need each other.

36. We do not spend enough time together.

37. We do not understand what is causing our difficulties.

38. Success and prestige are very Important to us.

39. We encourage each other to develop in his or her own Individual way.

40. We are sshamed of some things about our family.

41. We have warm, close relationships with each other.

42. There are some toples which we avold talking about. 
43, Together we can overcome almost any difficulty.

44. We really do trust and confide in each other.

45. We make many demands on each other.

46. We take care of each other.

47. Our activitles together are usually planned and organized.

48. The family has always been very important to us.

-49. We get more than our share of 111 ness.

50. We are considerate of each other.

51. We can stand up for our rights if necessary.

52. We are all responsible for our family problems.

53. There is not enough discipline in our family.

54. We have very good times together.

55. We depend on each other too much.

56. We often become angry at each other.

-57. We live largely by other people's standards and values.

58. We are not as happy together as we might be.

59. We are critical of each other.

60. We are satisfled with the way in which we now live.

-61. Usually each of us goes his own separate way.

-62. We resent each other's outside activities.

63. We have respect for each other's feelings and opinions even when we differ strongly.

-64. We sometimes wish we could be an entirely different family.

65. We are soclable and really enjoy being with people.

-66. We are a disorganized family.

67. It is 1mportant to us to know how we appear to others.

-68. Our decisions are not our own, but are forced upon us by circums tanies.

-69. We are not really fond of one another.

70. He are a strong, competent family.

-71. We just cannot tell each other our real feelings.

-72. We are not satisfled with anything short of perfection.

73. We forgive each other easily.

74. We are usually somewhat reserved with each other.

75. We rarely hurt each other's feelings.

76. We like the same things.

77. We usually reach decistons by discussion and compromise.

78. We can adjust well to new situat1ons.

79. We are liked by most people who know us.

80. We are full of life and good splrits. 
APPENDIX C

TOTAL SCORES OF SUBJECTS

Reproduced with permission of the copyright owner. Further reproduction prohibited without permission. 
APREIDIX $C$

TOTAL SCORES OF SUBUECTS

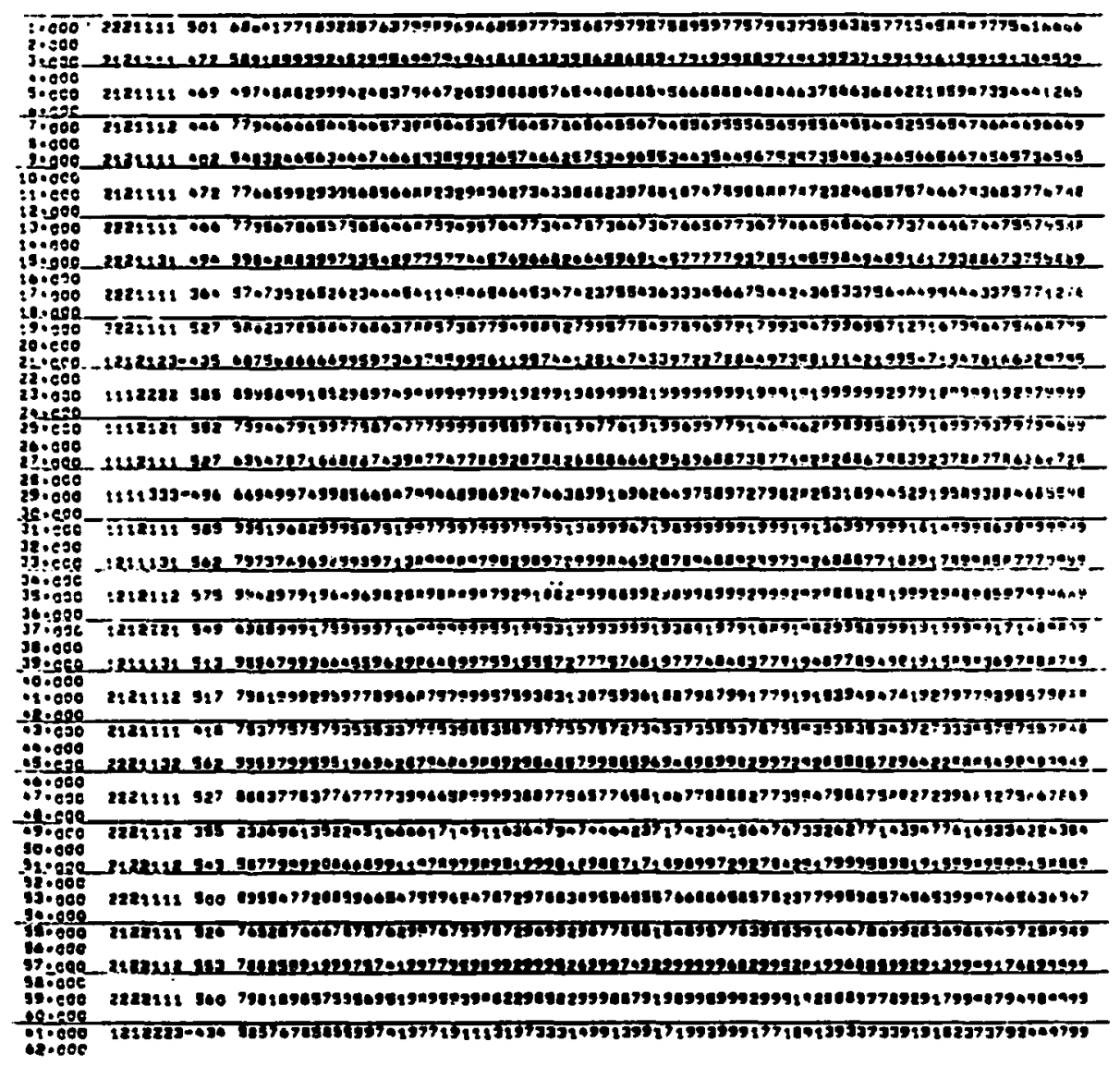


APPENDIX C

TOTAI SCORES OF SUBJECTS (CONHINUED)

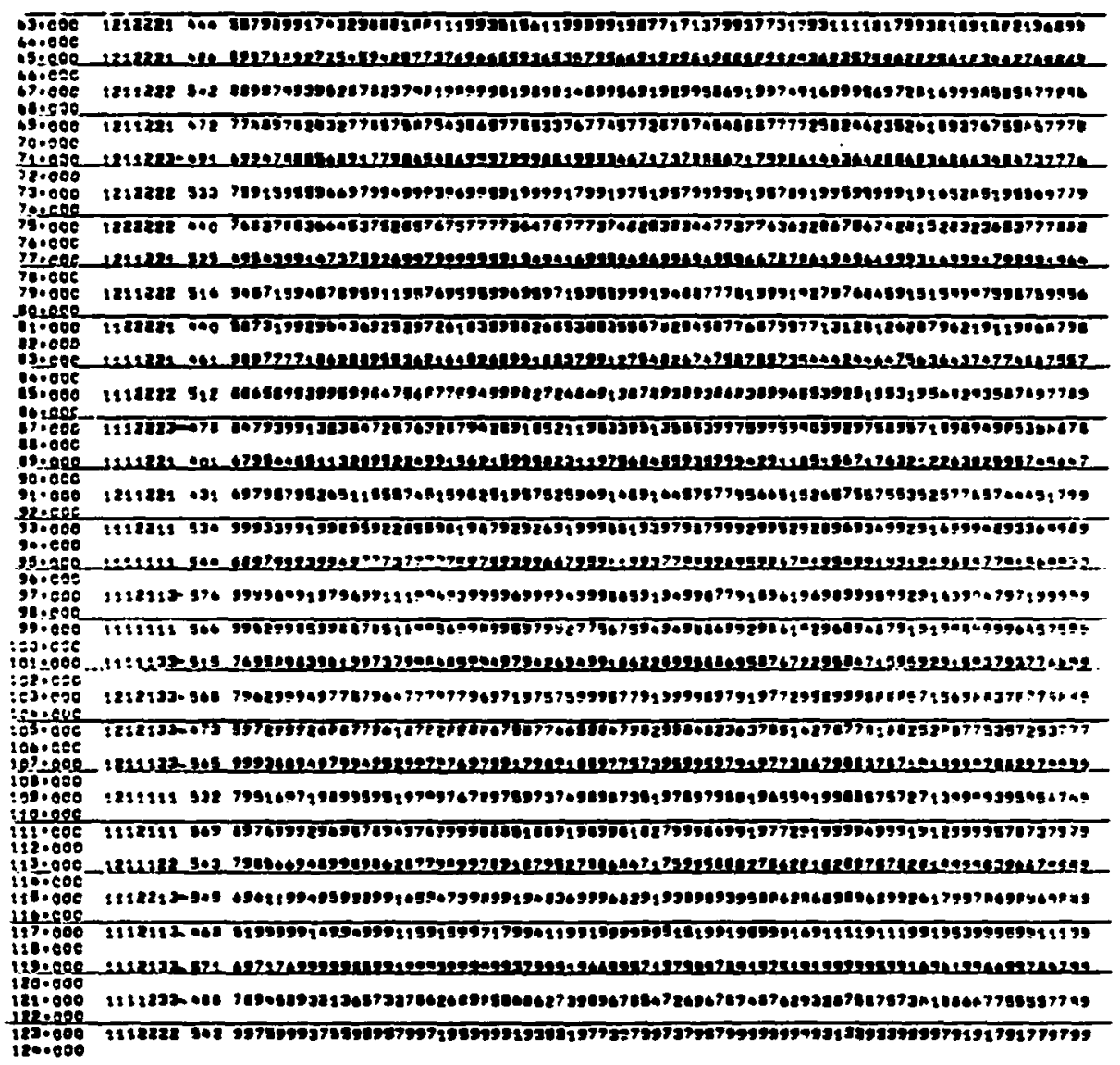

Reproduced with permission of the copyright owner. Further reproduction prohibited without permission 
APPENDIX C

TOTAE SCUSES GY SUBJECTS (CONTINUED)

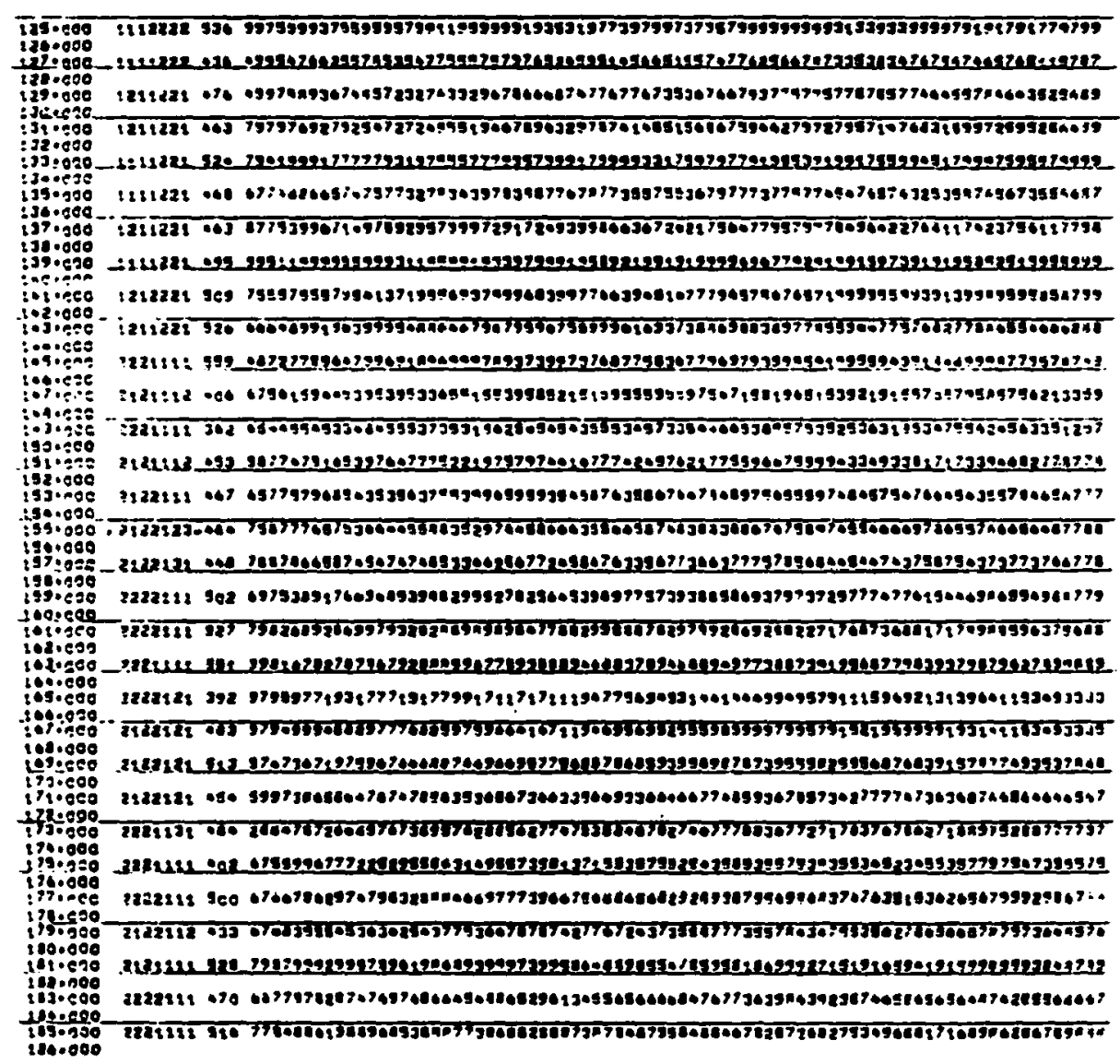

Reproduced with permission of the copyright owner. Further reproduction prohibited without permission. 
APPENTX C

TOTAL SCORES OP SUBJECTS (CONTTNUED)

\begin{tabular}{|c|c|}
\hline 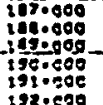 & 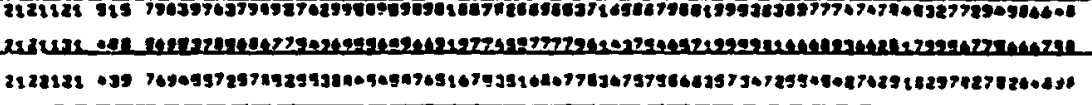 \\
\hline 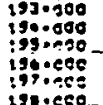 & 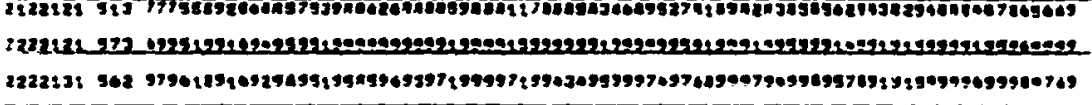 \\
\hline 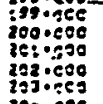 & 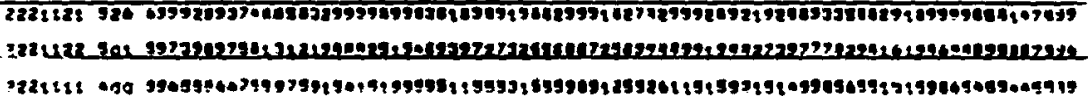 \\
\hline 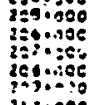 & 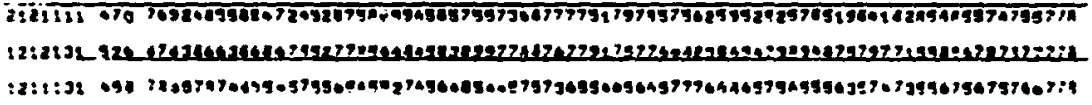 \\
\hline 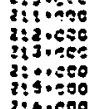 & 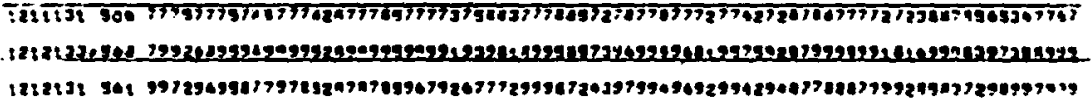 \\
\hline 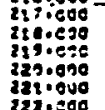 & 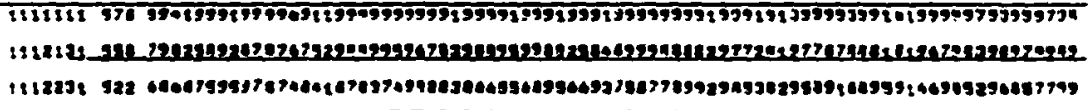 \\
\hline 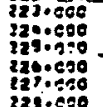 & 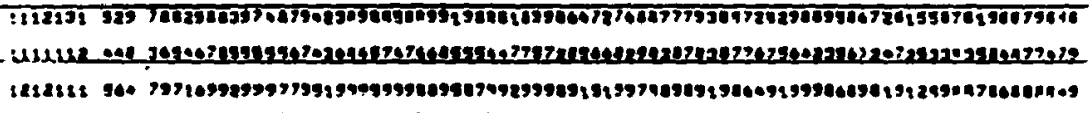 \\
\hline 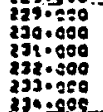 & 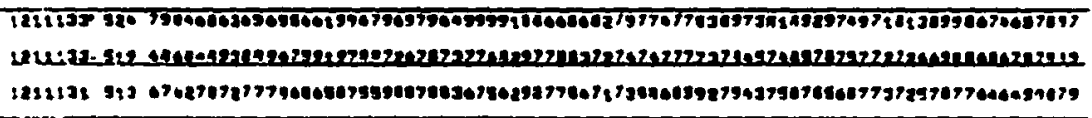 \\
\hline 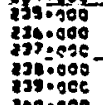 & 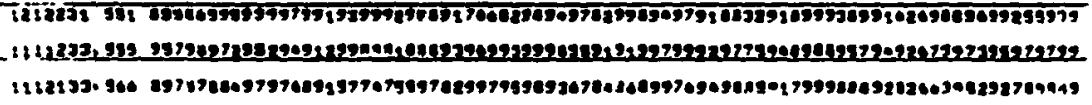 \\
\hline 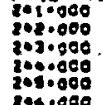 & 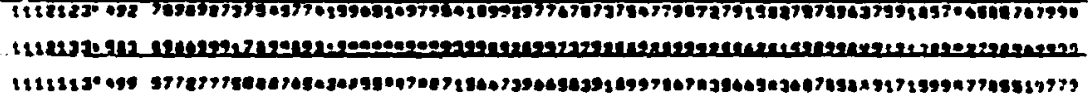 \\
\hline
\end{tabular}

Reproduced with permission of the copyright owner. Further reproduction prohibited without permission. 
APPENDIX D

AN $80 \times 80$ INTERCORRELATION MATRIX BETWEEN ITEMS

Reproduced with permission of the copyright owner. Further reproduction prohibited without permission. 
APpDidis D

AH $80 \times 80$ IXTERCORRELATION MATRIS BETWEEN ITEMS

\begin{tabular}{|c|c|c|c|c|c|c|c|c|c|c|}
\hline & T: & $:=25$ & & & & & & $y$ & & 38 \\
\hline & 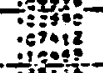 & 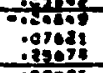 & 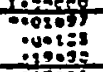 & 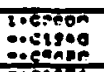 & 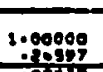 & 1.08590 & & & & \\
\hline & 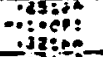 & 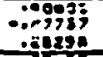 & 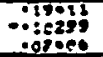 & 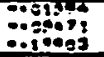 & 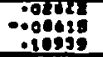 & 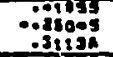 & 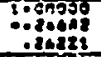 & $\begin{array}{l}3.009900 \\
-0.23933\end{array}$ & 1.00000 & \\
\hline & 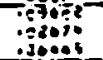 & 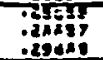 & 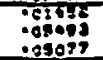 & 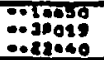 & $\begin{array}{r}-15015 \\
-12973 \\
\therefore 10210\end{array}$ & : & 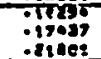 & 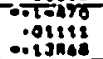 & 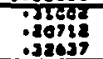 & $\begin{array}{l}\text { Faceses } \\
\text { :ajal } \\
\text { and }\end{array}$ \\
\hline & (j) & 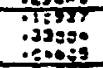 & 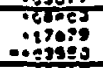 & 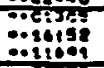 & 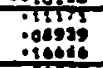 & 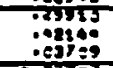 & 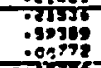 & 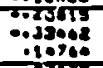 & 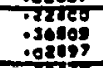 & 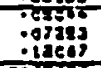 \\
\hline & 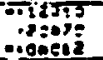 & 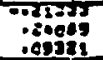 & 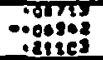 & 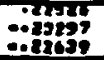 & 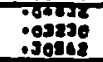 & 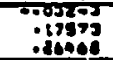 & $\begin{array}{l}77 y=6 \\
: 19492 \\
: 13290\end{array}$ & 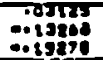 & 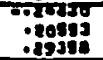 & 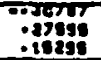 \\
\hline 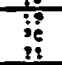 & 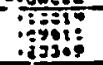 & 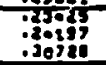 & 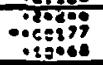 & 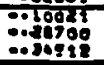 & 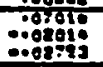 & 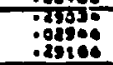 & 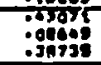 & 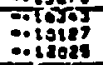 & 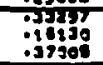 & 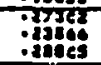 \\
\hline $\begin{array}{ll}71 \\
? !: 0\end{array}$ & 年 & 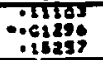 & 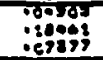 & 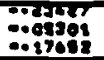 & 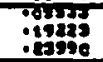 & 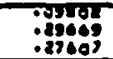 & 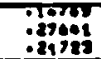 & 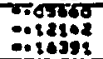 & 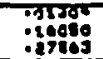 & 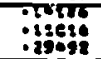 \\
\hline & 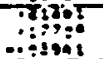 & 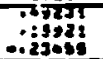 & 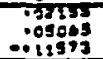 & :arys & $\begin{array}{c}\text { Twuty } \\
-100325 \\
-12000\end{array}$ & 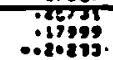 & 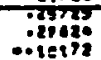 & 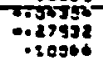 & 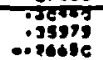 & 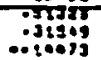 \\
\hline 3 & 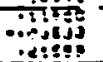 & 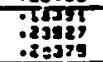 & 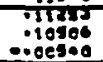 & 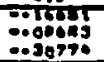 & 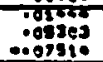 & 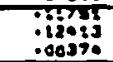 & $\begin{array}{l}: 30 \\
: 9008 \\
: 9900\end{array}$ & $\begin{array}{r}-\pi: 7 n j 5 \\
\text {-oe:es } \\
\text {-ogess }\end{array}$ & $\begin{array}{l}\text { Taspi: } \\
\text {-aspo: } \\
.19290\end{array}$ & 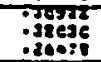 \\
\hline 䓜 & 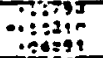 & 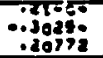 & 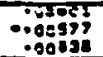 & 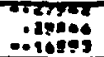 & 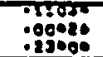 & 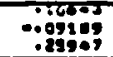 & 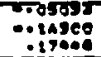 & 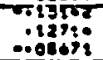 & -isuls & 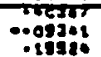 \\
\hline 30 & 年 & 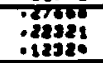 & 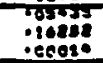 & 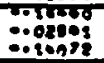 & 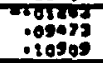 & 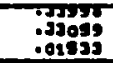 & 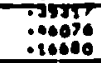 & 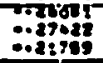 & 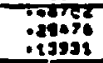 & 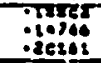 \\
\hline ja: & 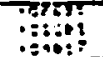 & 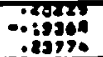 & 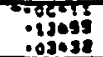 & 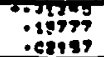 & 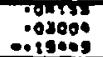 & $\begin{array}{l}\text {.37ng? } \\
.072 \% 0\end{array}$ & $\begin{array}{l}.72101 \\
.09912 \\
.30061\end{array}$ & 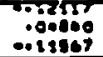 & 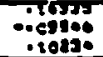 & 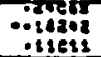 \\
\hline$\pi$ & 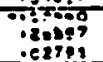 & 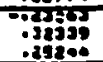 & 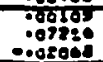 & 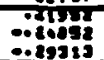 & 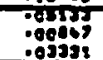 & דithis & 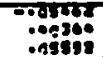 & 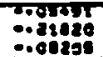 & Tixps & $\begin{array}{l}\text { Thyos } \\
\text {-17pes }\end{array}$ \\
\hline & 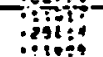 & 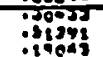 & 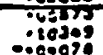 & :Eves & 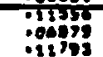 & 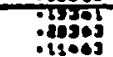 & :39ges & motit & :enth & $\begin{array}{l}7415 \\
0270.09\end{array}$ \\
\hline 0 & $\begin{array}{l}6350 \\
10495 \\
112002\end{array}$ & 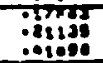 & 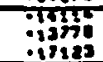 & 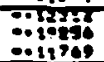 & 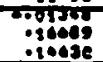 & 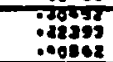 & 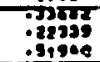 & 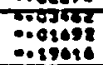 & 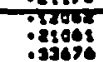 & 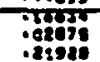 \\
\hline 90 & 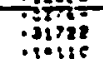 & 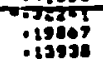 & 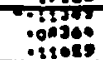 & roves & 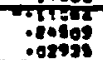 & 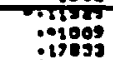 & $\begin{array}{l}\text { Tyigus } \\
\text {-astee }\end{array}$ & $\begin{array}{l}-07 r 00 \\
021912\end{array}$ & 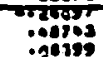 & -7xin \\
\hline ไี & 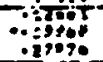 & 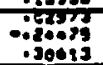 & 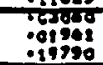 & $\begin{array}{l}\text { Oytey } \\
\text {-istent }\end{array}$ & $\begin{array}{l}\text { Oughts } \\
\text {-osces }\end{array}$ & $\begin{array}{l}-00703 \\
-00330\end{array}$ & 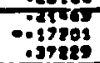 & 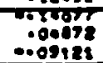 & 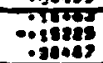 & 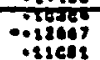 \\
\hline & 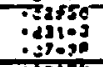 & 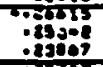 & 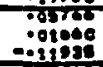 & 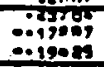 & 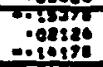 & $\begin{array}{l}-1245 \\
.1805 \\
.00000\end{array}$ & 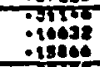 & 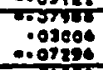 & 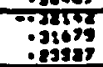 & 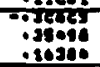 \\
\hline & 7r:56 & oryest & $\begin{array}{l}-71002 \\
-000248\end{array}$ & Thy yू & .0000 & .06019 & - teces & $\because$ agurs & .97802 & 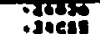 \\
\hline & :ajp & -gyou & ogrtas & Eorjing & ofyur & - isit & -97938 & $\begin{array}{l}\because 001244 \\
\because-10670\end{array}$ & - Orys & -0096 \\
\hline$\therefore$ & - 0040 & 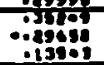 & 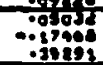 & $\begin{array}{l}\text {-atis } \\
- \text { inges }\end{array}$ & 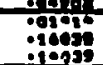 & 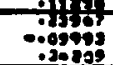 & -18970 & 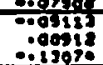 & 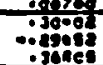 & -iviez \\
\hline & 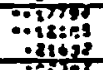 & 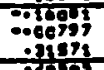 & 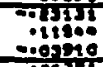 & 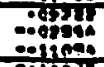 & "arys & 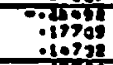 & 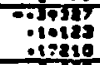 & 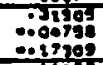 & 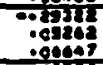 & 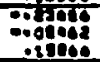 \\
\hline 8 & 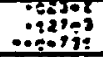 & 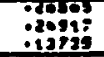 & 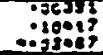 & agipe & - 19790 & 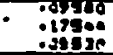 & :aspes & 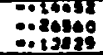 & 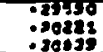 & 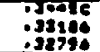 \\
\hline is & 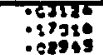 & 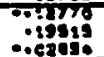 & 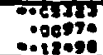 & $\therefore 6404$ & 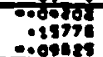 & 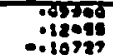 & $\begin{array}{l}\text { Thy } \\
.80909 \\
.10909\end{array}$ & 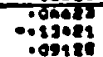 & 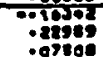 & -cing \\
\hline$\because$ & 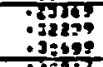 & 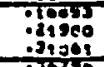 & 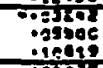 & 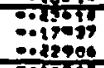 & 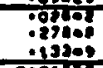 & $\begin{array}{r}.01000 \\
.12180 \\
.2015 \\
\end{array}$ & $\begin{array}{l}01104 \\
.2939 \\
\end{array}$ & 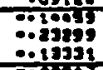 & $\begin{array}{l}09115 \\
: 20200 \\
.00102 \\
\end{array}$ & 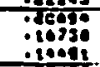 \\
\hline$\therefore$ & 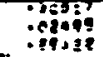 & 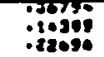 & 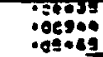 & $\begin{array}{l}\therefore \text { irean? } \\
\therefore \text { ireas }\end{array}$ & 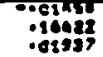 & Thess & : 190353 & 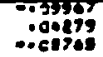 & -283598 & 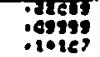 \\
\hline
\end{tabular}


APPENDIX D

AN 80 I 80 INTERCORRELATION YATRIX BETWEEN ITEMS (CONTINOED)

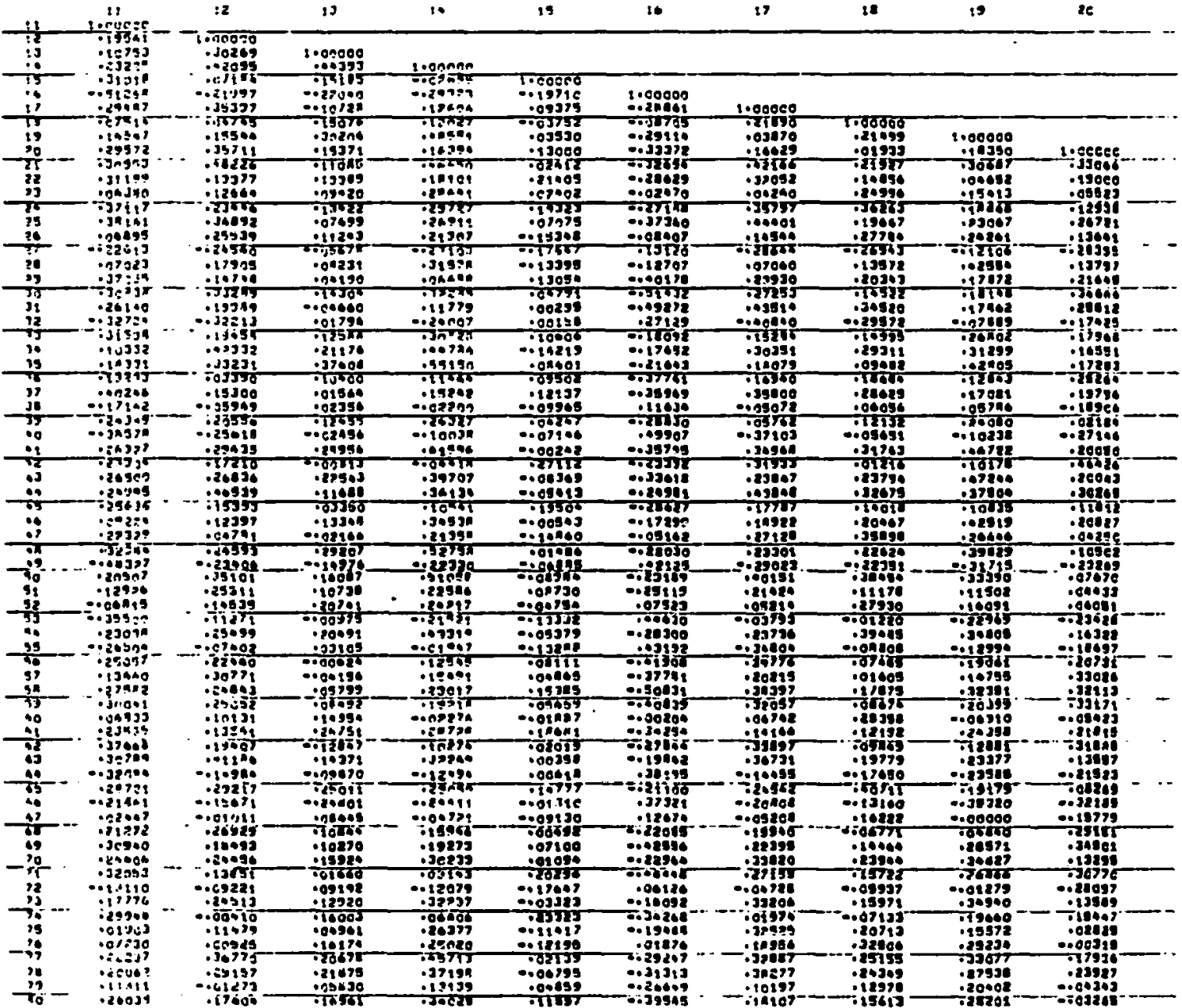


APPENDIX D

AN 80 X 80 INTERCORRELATION MEATIX BETWEEN ITEMS (CONTINUED)

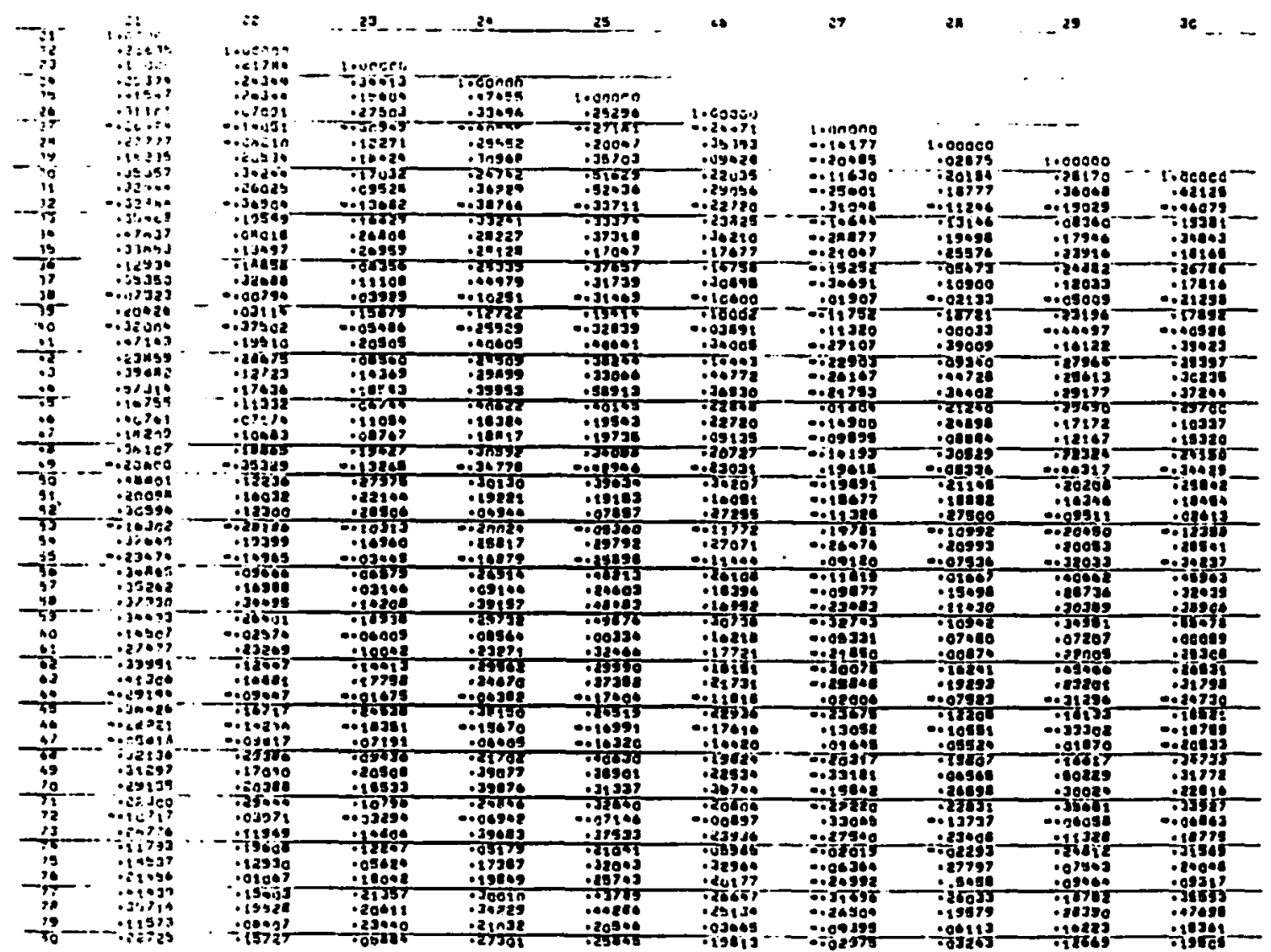


APPENDIS D

AN $80 \times 80$ INTERCORRELATION MTRIX BETWEEN ITEUS (CONTINUED)

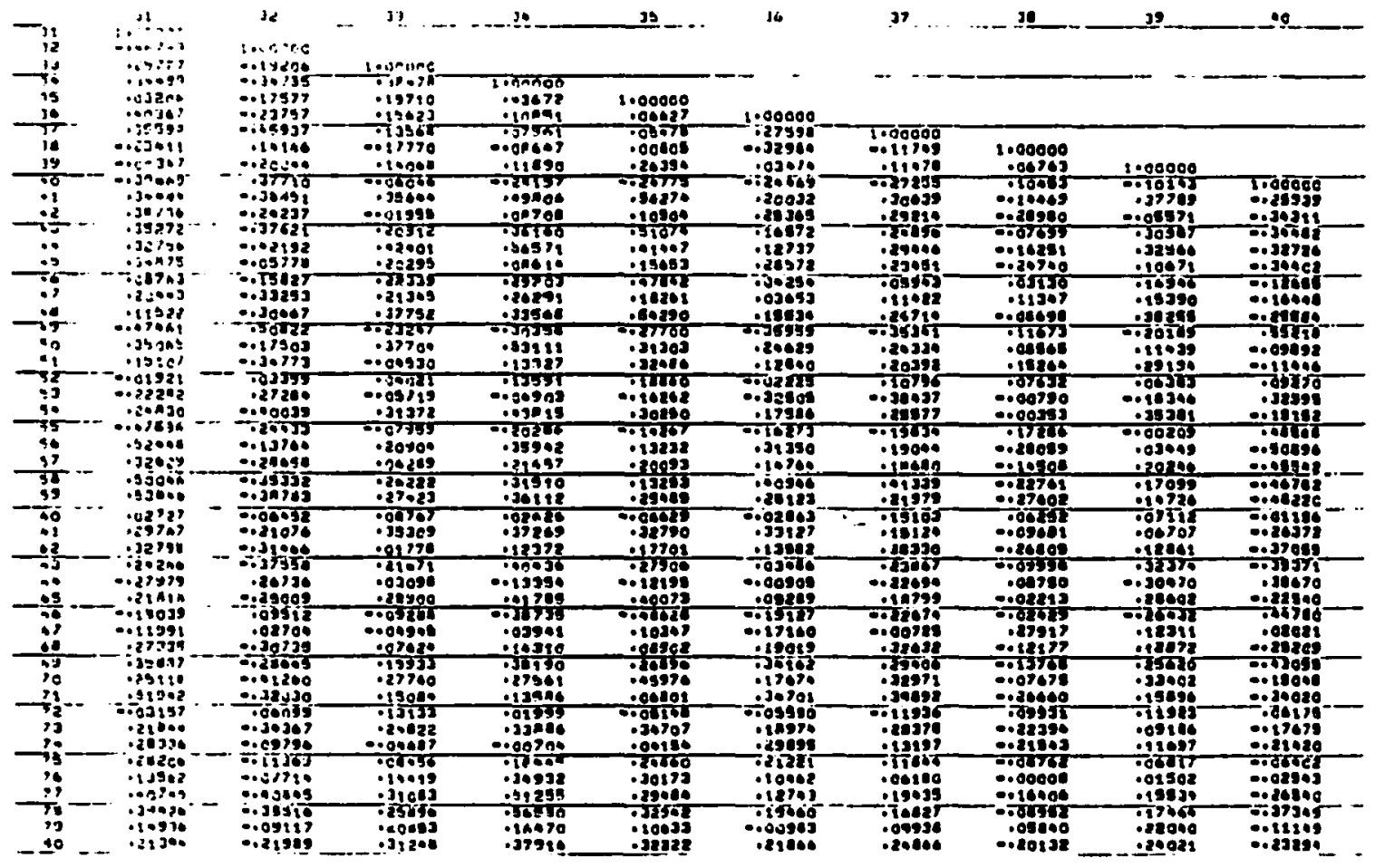


APPENDIX D

AN 80 x 80 INTERCORRELATION MATRIX BETWEEN ITEUS (CONTINUED)

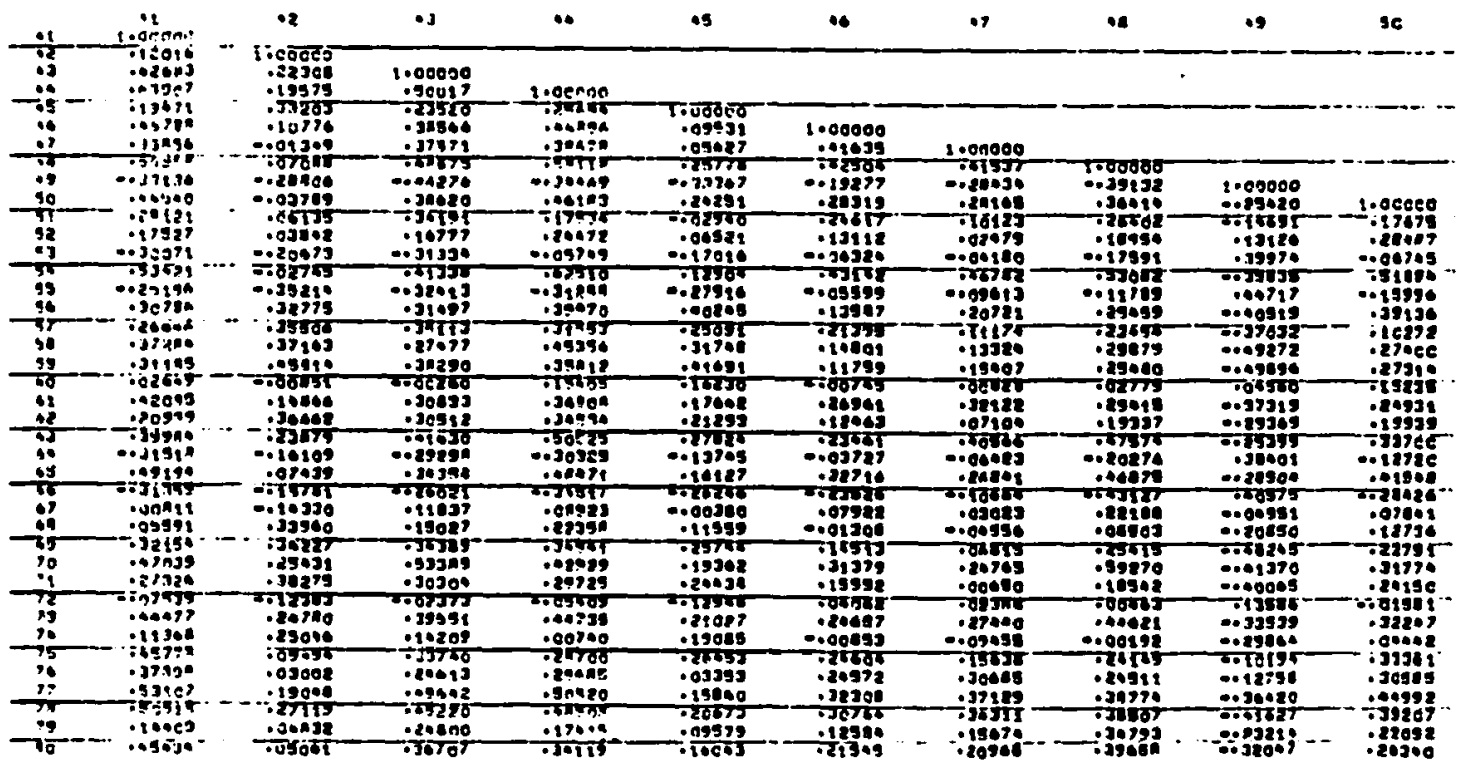

Reproduced with permission of the copyright owner. Further reproduction prohibited without permission. 
APPENDIX D

AN 80 X 80 INTERCORAELATION MATRIX BETWEEN ITENS (CONTINUED)

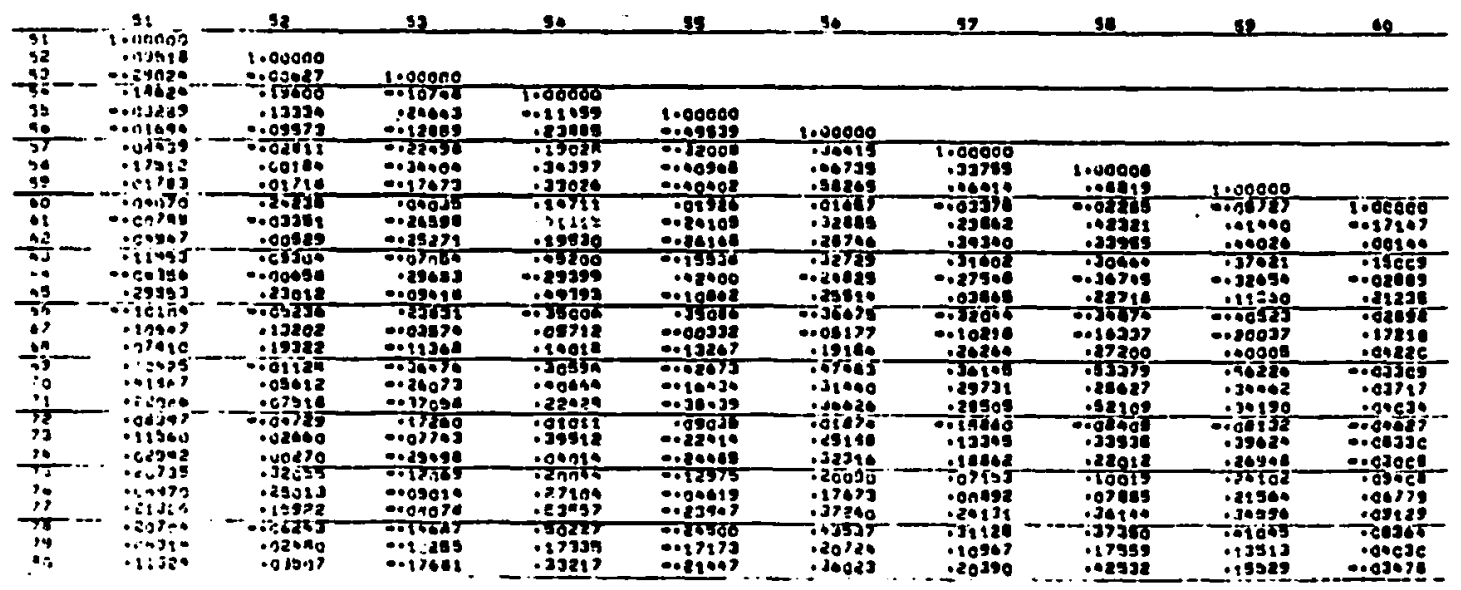


APPENDIX D

AN $80 \times 80$ INTERCORRELATION MATRIX BETWEEN ITEUS (CONTINOED)

\begin{tabular}{|c|c|c|c|c|c|c|c|c|c|c|}
\hline &.$\therefore$ & $\because$ & .3 & 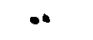 & 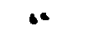 & $n$ & 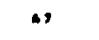 & 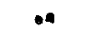 & -9 & ic \\
\hline & 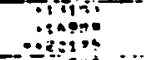 & 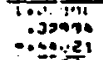 & $\begin{array}{l}\text { Ionnnos } \\
\because a \operatorname{ag} 10 \\
\end{array}$ & $1.0 .9-9.4 n$ & & & & & & \\
\hline & 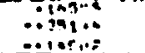 & 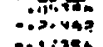 & 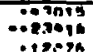 & 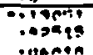 & 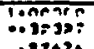 & 10. 2uonen & & & & \\
\hline & ה:3 & 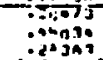 & 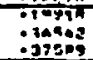 & 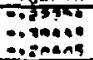 & non: & 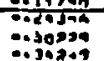 & 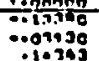 & 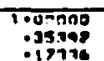 & 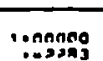 & \\
\hline & 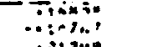 & $\because \because 3=0$ & $\therefore$ & $\begin{array}{l}\text { manhn } \\
\text { orise }\end{array}$ & 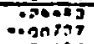 & $\begin{array}{l}\text { OPanas } \\
\text { ofiakn }\end{array}$ & injopos & ocsis & anings & 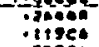 \\
\hline & 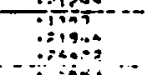 & 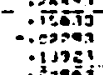 & 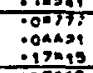 & 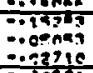 & 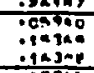 & 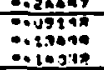 & 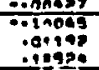 & 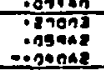 & 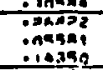 & 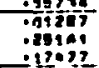 \\
\hline$\because$ & 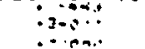 & 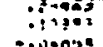 & 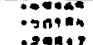 & 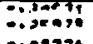 & antas & 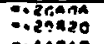 & $\because \because 3943$ & 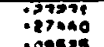 & : & 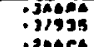 \\
\hline & $-\div ; \div$ & 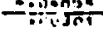 & $\div \frac{1}{-2.725}$ & 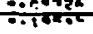 & anting & 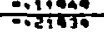 & (anano & 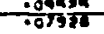 & 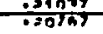 & $\frac{2}{2}$ \\
\hline
\end{tabular}

Reproduced with permission of the copyright owner. Further reproduction prohibited without permission. 
APPENDIX D

AN $80 \times 80$ TWTERCORRELATION MATRIX BETWEEN ITEUS (CONTINUED)

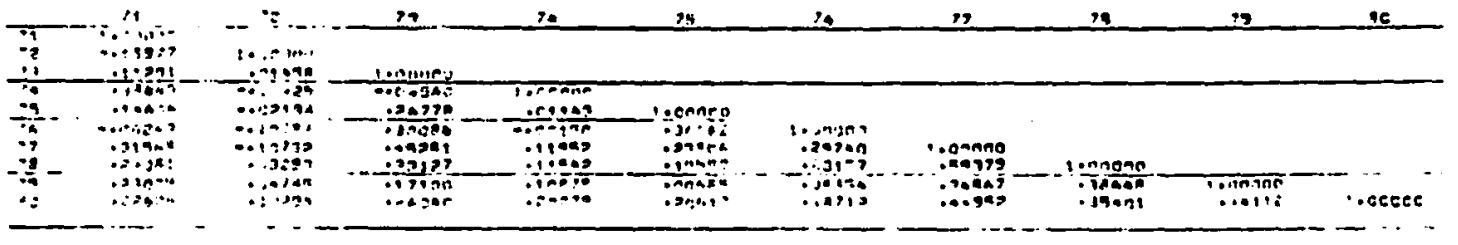

Reproduced with permission of the copyright owner. Further reproduction prohibited without permission. 
APPENDIX E

AN 80 X 12 CORRELATION MATRIX BETWEEN

ITEMS AND FACTORS

Reproduced with permission of the copyright owner. Further reproduction prohibited without permission. 


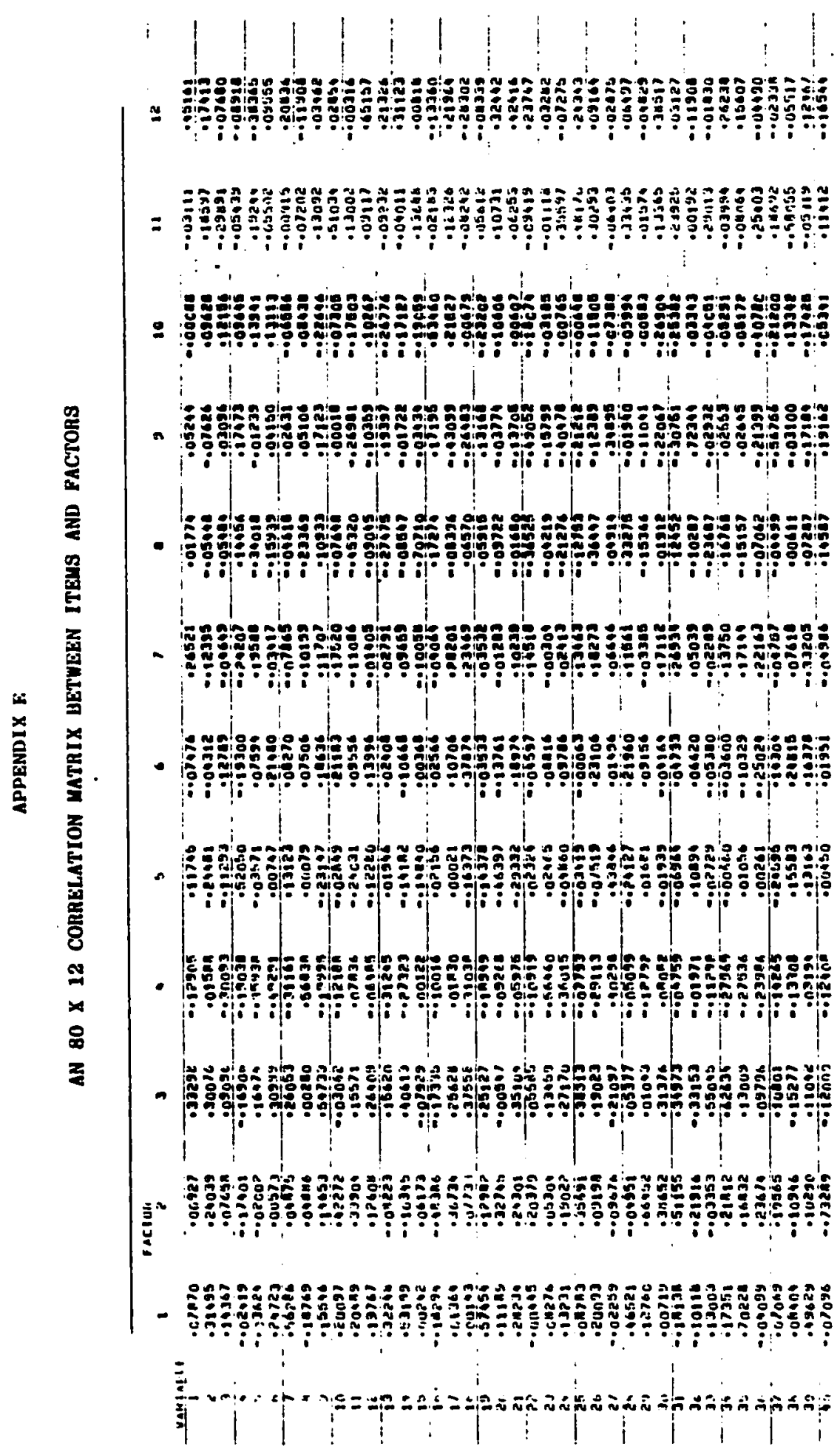

Reproduced with permission of the copyright owner. Further reproduction prohibited without permission. 


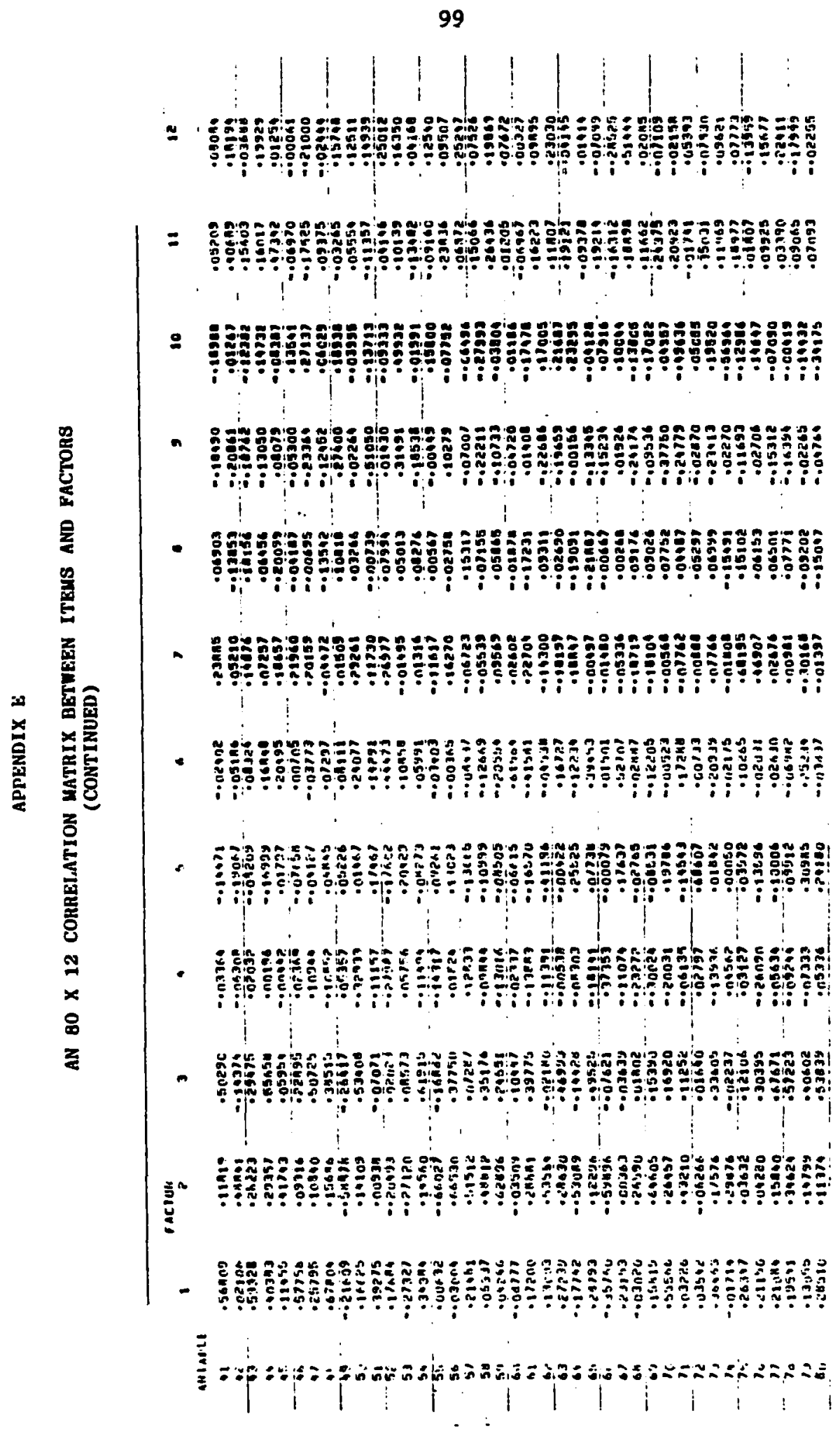

Reproduced with permission of the copyright owner. Further reproduction prohibited without permission. 


\section{APPENDIX F}

\section{A $123 \times 12$ CORRELATION MATRIX FOR FACTOR SCORES}


AN $123 \times 12$ CORRELATION MATRIX FOR FACTOR SCORES

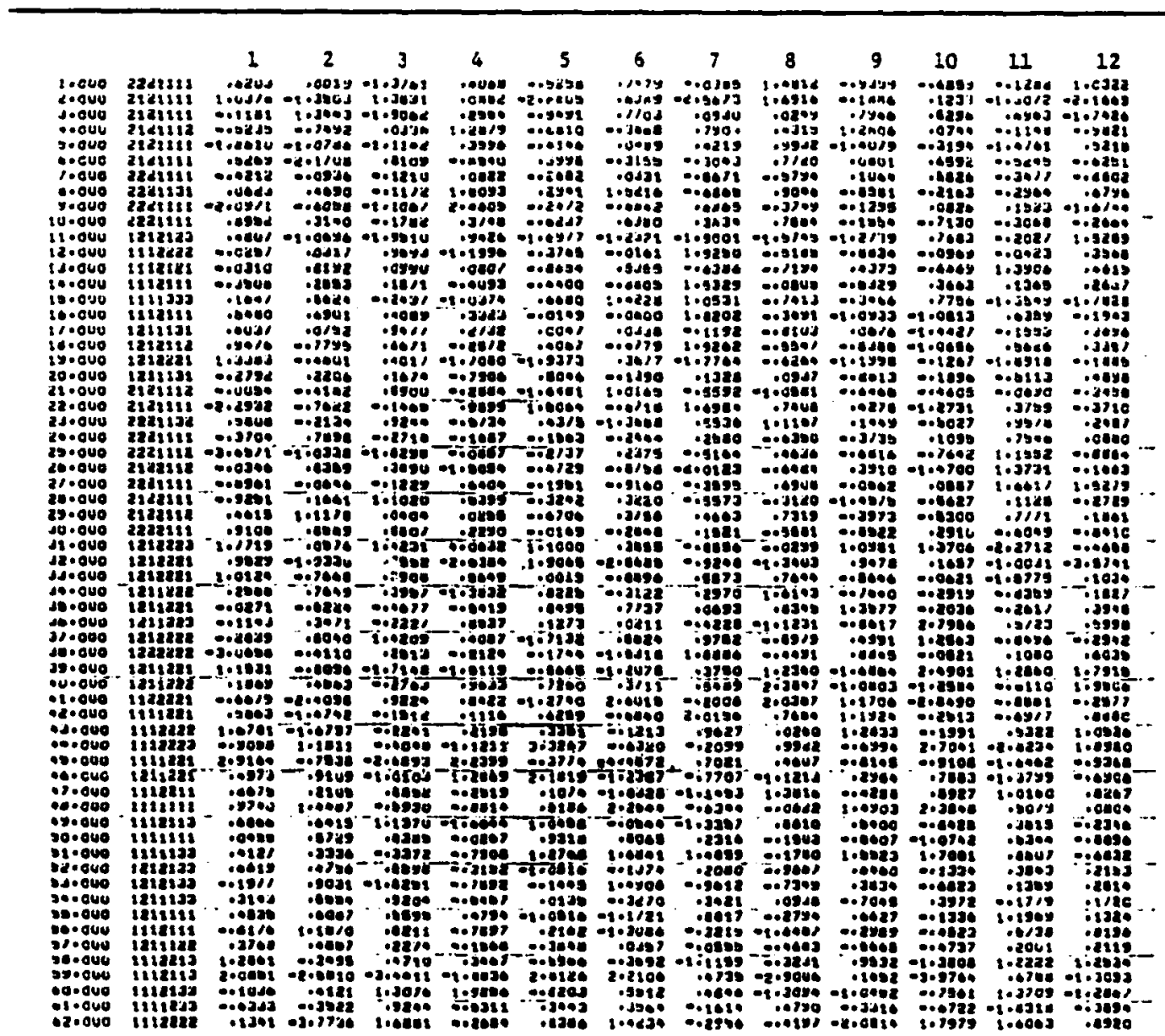


APPEDIX F

AN 123 I 12 CORRELATION YATRIX FOR FACTOR SCORES

(CONTINUED)

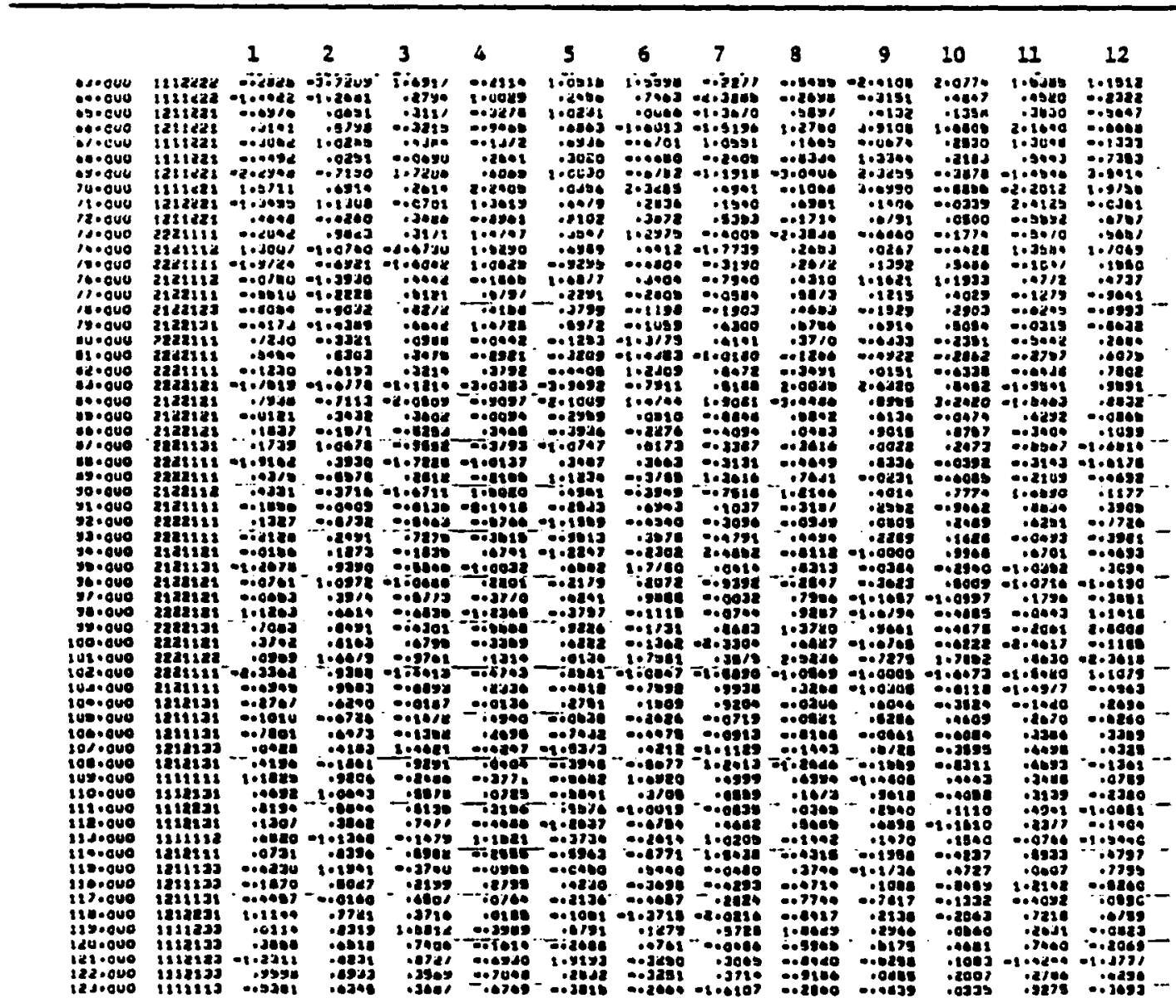


APPENDIX $G$

FACTOR MEANS ON ALL GROUPS ON ALL FACTORS

Reproduced with permission of the copyright owner. Further reproduction prohibited without permission. 
TABLE 26

FACTOR MEANS ON ALL GROUPS ON ALL FACTORS

\begin{tabular}{|c|c|c|c|c|c|c|c|}
\hline & \multirow{2}{*}{ Factor } & \multicolumn{2}{|c|}{ Grade } & \multicolumn{2}{|c|}{ Church Membersh1p } & \multicolumn{2}{|c|}{ Sex } \\
\hline & & Nintli: & Twelf th & S.D.A. & Non-SDA & Male & Female \\
\hline I. & Atcachment & 509.29 & 490.77 & 524.97 & 466.92 & 482.91 & 519.70 \\
\hline II. & Emotional Opienness & 484.05 & 515.74 & 506.10 & 492.00 & 508.61 & 490.09 \\
\hline III. & Compatibility & 504.70 & 495.39 & 523.63 & 468.81 & 481.12 & 521.88 \\
\hline IV. & Inadequacy & 501.89 & 498.08 & 494.83 & 506.75 & 512.48 & 485.47 \\
\hline v. & IndLviduality & 507.93 & 492.27 & 518.71 & 475.38 & 507.76 & 491.11 \\
\hline vI. & Interdependence & 520.26 & 480.68 & 493.17 & 509.04 & 508.86 & 489.75 \\
\hline VII. & Mutual Support & 509.02 & 491.13 & 504.60 & 493.92 & 495.83 & 504.82 \\
\hline VIII. & Pseudo-confidence & 502.03 & 498.03 & 479.93 & 526.55 & 512.89 & 485.11 \\
\hline IX. & Frustration & 503.67 & 496.37 & 505.56 & 492.64 & 501.52 & 498.23 \\
\hline $\mathrm{x}$. & Communication & 500.00 & 500.03 & 505.21 & 493.15 & 505.65 & 493.49 \\
\hline XI. & Autonomy & 508.79 & 491.37 & 509.03 & 488.09 & 493.85 & 507.14 \\
\hline KII. & Democracy & 485.39 & 514.16 & 510.74 & 485.79 & 495.50 & 505.19 \\
\hline
\end{tabular}


TABLE 26

FACTOR MEANS ON ALL GROUPS ON ALL FACTORS (CONTINUED)

\begin{tabular}{|c|c|c|c|c|c|c|c|c|}
\hline & \multirow{2}{*}{ Factor } & \multicolumn{2}{|c|}{ Race } & \multicolumn{3}{|c|}{ Residential Location } & \multicolumn{2}{|c|}{ Parental Number } \\
\hline & & White & Non-White & Rural & Urban & Suburban & Both & One \\
\hline I. & Attachment & 492.43 & 518.17 & 489.14 & 505.32 & 509.77 & 497.90 & 489.59 \\
\hline II. & Emottonal Openness & 513.11 & 468.39 & 494.71 & 476.59 & 539.80 & 508.12 & $446 . ! 14$ \\
\hline III. & Compatibil1ty & 487.87 & 529.33 & 480.88 & 499.98 & 531.30 & 492.90 & 505.32 \\
\hline IV. & Inadequacy & 497.23 & 506.58 & 505.14 & 499.89 & 491.63 & 499.60 & 508.41 \\
\hline v. & Individuality & 483.40 & 540.25 & 489.24 & 513.09 & 498.53 & 487.77 & 508.32 \\
\hline VI. & Interdependence & 507.28 & 482.44 & 497.75 & 494.16 & 512.27 & 488.88 & 514.12 \\
\hline VII. & Mutual Support & 503.14 & 492.42 & 494.53 & 496.25 & 514.43 & 503.59 & 510.58 \\
\hline VIII. & Pseudo-confidence & 495.18 & 511.69 & 500.63 & 505.09 & 491.59 & 503.56 & 523.27 \\
\hline IX. & Frustration & 490.32 & 523.36 & 486.18 & 508.75 & 509.70 & 507.51 & 476.32 \\
\hline $\mathbf{x}$. & Communication & 488.59 & 527.66 & 474.61 & 537.32 & 486.80 & 493.81 & 509.79 \\
\hline $\mathbf{X I}$ & Autonomy & 508.71 & 478.97 & 521.59 & 468.59 & 510.83 & 487.06 & 550.14 \\
\hline XII. & Democracy & 489.98 & 524.19 & 487.53 & 516.43 & 496.23 & 498.92 & 512.99 \\
\hline
\end{tabular}


BIBLIOGRAPHY

Reproduced with permission of the copyright owner. Further reproduction prohibited without permission. 


\section{BIBLIOGRAPHY}

Ayers, E. G. "A Study of Conflict Between Parents in Clinic and NonClinic Families." Ph. Di dissertation, University of Ransas, 1965.

Baverman, E. E.; and Elders, G. H., Jr. "Varfations In Adolescent Perception of Family Power Structure." American Sociological Review 29 (August 1964): 551-567.

Berkowitz, N. "Perceived Family Relationships In Families Differing in Adjustment Level." M. A. thesis, University of Wisconsin, 1963.

Broderick, C. B. "Beyond the Five Cunceptual Frameworks: A Decade of Development in Family Theory." Journal of Marriage and the Family 33 (February 1971): 139-159.

Campbell, E. 0. "Adolescent Socialization." In Handbook of Socialization Theory and Research, pp. 821-859. Edited by David Goslin. Chicago; Rand McNally and Company, 1969.

Chaffee, S. H.; Mcleod, J. M.; and Atkin, C. R. "Parental Influences on Adolescent Media Use." American Behavioral Scientist 14 (1971): $323-340$.

Christensen, H. T. "Development of the Family Fleld of Study." In Handbook of Marriage and the Family, Pp. 3-32. Edited by Harold T. Christensen. ChIcago: Rand McNally and Company, 1964 .

Cogswell, B. E. "Soclalization into the Family: An Essay on Structural Prospects of Roles." In Sourcebook in Marriage and the Family, pp. 366-377. Edited by Marvin Sussman. Boston: Houghton Mifflin Company, 1968.

Coleman, D. D. "Family Bullding for Adolescents: A Model of Developmental Learning Tasks." Ph. D. dissertation, Ohio State University, 1973.

Cooley, C. H. Buman Nature and the Soclal Order. New York: Schocken, 1964 .

Crandall, v. C. "Personality Characteristics, and Soclal and Achlevement Behaviors Associated with Children's Soclal Desirability Response Tendenctes." Journal of Personality and Social Psychology 4 (1966): 477-486. 
Crosby, J. F. "The Effect of Family Life Education on the Values and Attitudes of Adolescents." Family Coordinator 20 (Apr11 1971): 137-140.

Dahlemn, N. W. "Young Americans' Reported Perceptions of Thefr Parents." Journal of Psychology 74 (1970): 91-97.

Davis, K. "The Soclology of Parent-Youth Conflict." American Soclological Review 5 (August 1940): 523-535.

Douvan E.; and Andelson, J. The Adolescent Experlence. New York: John Wiley and Sons, Inc., 1966.

Duvall, E. M. Family Development, revised edition. New York: J. B. Lippincott Company, 1971.

Elkind, D. "Cognitive Development in Adolescents." In Understanding Adolescence, pp. 353-380. Edited by J. F. Adam. Boston: Allyn and Bacon, Inc., 1968.

- "Egocentrism in Adolescence." Child Development 38 (December 1967): 1025-1034.

Eppel, E.; and Eppel, M. "Connotations of Morality: The Views of Some Adults on the Standards and Behavior of Adolescents." British Journal of Soclology 13 (September 1962): 243-263.

Erikson, E. H. Ident1ty and the Life Cycle: Selected Papers. New York: International University Press, 1961.

. "Youth, Fidelity and Diversity." In Youth: Change and Challenge, PP. 1-23. Edited by E. H. Erikson. New York: Basic Books, 1963. - Identity, Youth and Crisis. New York: W. W. Norton, Publishers, 1968 .

Fodor, E. M. "Moral Development and Parent Behavior Antecedents in Adolescent Psychopaths." Journal of Genetic Psychology 122 (March 1973): 37-43.

Haidle, W. D. "A Comparison of Adolescent Perceptions of ParentChild Relationships between Delinquent and Non-delinquent Adolescents." Ed. D. dissertation, Montana State University, 1974.

Hardcastle, D. R. "Effects of a Family Counseling Program on Parents' Family Satisfaction, Percelved Integration, and Congruence, and on Specific Behavior Patterns in the Family." Ph. D. dissertation, Brigham Young University, 1973.

Herzog, E.; and Sudia, C. E. "Fatherless Homes: A Review of Research." Children 15 (Sep.-Oct., 1968): 177-182. 
Hess, R. D.; and Goldblatt, I. "The Status of Adolescents in American Society: A Problem in Soclal Identity." Child Development 28 (December 1957): 459-468.

Hewitt, D. W. "The Family Adjustment of Culturally Deprived Adolescent Males in Relation to their Perception of Family Problems." Ph. D. dissertation, Florida State University, 1967.

Hill, R.; and Hensen, D. A. "The Identification of Conceptual Frameworks Ut1lized in Family Study." Marriage and Family Living 22 (November 1960): 299-311.

Hill, R.; and Rodgers, R. H. "The Developmental Approach." In Handbook of Marriage and the Family, pp.171-211. Edited by Harold T. Christenson. Chicago: Rand McNally and Company, 1964.

Holland, D. "Familization, Soctalization, and the Universe of Meaning: An Extension of the Interactional Approach to the Study of the Family." Journal of Marrlage and the Family 32 (August 1970): 415-427.

Holtzman, W. H.; and Moore, B. Tomorrow's Parents: A Study of Youth and their Families. Austin: University of Texas Press, 1965.

Howe, L. L. The Future of the Family. New York: Simon and Schuster, 1972.

Janzen, C. "A Study of the Relationships between Parental Family Concepts and Child Personality in Disturbed Children." Ph. D. dissertation, University of Chicago, 1972.

Jersild, A. T. The Psychology of Adolescence, 2nd edition. New York: The Macmillan Company, 1963.

Keniston, K. "Social Change in Youth in America." In Change and Challenge, pp. 161-187. Edited by E. H. Erikson. New York: Bastc Books, 1963.

Kerlinger, F. N. Foundations of Behavioral Research. New York: Holt, Rinehart, and Winston, Inc., 1973.

Kimmel, D. C. "Interacting Family Components: An Analysis of the Interrelationship between Child Behavior, Marital Adjustment and Family Perceptions." Ph. D. dissertation, University of ChIcago, 1970.

King, K. "Adolescent Perception of Power Structure in the Negro Family." Journal of Marriage and the Family 31 (November 1969): $75 \overline{1-755 .}$ 
Rirkpatrick, C. "Familial Development, Selective Needs, and Predictive Theory." Journal of Marrlage and the Family 29 (May 1967): 229-236.

Klein, J. F.; Calvert, G. P.; Garland, N.; and Poloma, M. H. "Pilgrims' Progress I: Recent Developments in Family Theory." Journal of Marriage and the Family 31 (November 1969): $67 \overline{7-687 .}$

Kruger, S. W. "Education for Parenthood and School." American Education 8 (December 1972): 25-28.

Larson, L. E. "System and Subsystem Perception of Family Roles." Journal of Marriage and the Family 36 (February 1974): 123-137.

Lorenz, E. K. "Contemporary American Family Life as Depicted by Illustrations in Primary Level Basal Readers." Ph. D. dissertation, Syracuse UnIversity, 1970.

Maxwe11, J. W.; and Montgomery, J. E. "Societal Pressure Toward Early Parenthood." Family Coordinator 18 (October 1969): 340-344.

Maxwell, R. H.; Connor, R.; and Walters, J. "Family Member Perceptions of Parent Role Performance." Merr111-Palmer Quarterly of Behavior and Development 7 (January 1961): 31-37.

McInt1re, W. G.; Nass, G. D.; and Preyer, A. S. "Parental Role Perceptions of Ghanian and American Adolescents." Journal of Marriage and the Family 36 (February 1974): 184-189.

Mead, G. H. Mind, Self and Soclety. Chicago: University of Chicago Press, 1934.

Melssner, w. w. "Parental Interaction of the Adolescent Boy." The Journal of Genetic Psychology 107 (December 1965): 225-233.

Murdock, G. P. Social Structure. New York: The Macmillan Company, 1965.

Musgrove, F. "The Social Needs and Satisfactions of Some Young People." British Journal of Educational Psychology 36 (1966): $6 \overline{1-71 . ~}$

Parsons, T.; and Bales, R. F. Family, Soclalization and Interaction Process. New York: Free Press, 1955. 
PItts, J. R. "The Structural-Functional Approach." In Handbook of Marriage and the Family, pp. 51-124. Edited by Harold T. Christensen. Chicago: Rand McNally and Company, 1964.

Raskin, N. J.; and van der Veen, F. "Client-centered Family Therapy: Some Clinical and Research Perspective." In New Directions in Client-Centered Therapy, pp. 387-406. Edited by J. T. Hart and T. M. Tomlinson. New York: Roughton Mifiln and Company, 1970.

Relter, G. F.; and Kilmann, P. R. "Mothers as Family Change Agents." Journal of Counseling Psychology 22 (Jan.-Feb. 1975): $61-65$.

Rooks, E.; and King, R. "Study of the Marriage Role Expectations of Black Adolescents." Adolescence 8 (Fall 1973): 317-324.

Sailer, W. S. "Family Perception and Its Relation to Personalfty and and Adfustment Factors in the Child." M. A. thesis, Univeristy of Kansas, 1967.

Schab, F. "Attitudinal Differences of Southern White and Negro Adolescent Males Regarding the Home, School, Religion, and Morality." Journal of Negro Education 40 (Spring 1971): 108-110.

Schultz, A. D. The Changing Family: Its Function and Future. Englewood Cliffs, New Jersey: Prentice-Ha11, Inc., 1972.

Slocum, W. L.; and Stone, C. L. "A Method for Measuring Family Images Held by Teenagers." Marriage and Family LIving 21 (August 1959): 245-250.

Snow, C. "Differential Marriage and Family Perceptions and Attitudes of Adolescents Living in Child Care Institutions and Adolescents Living in Intact Familles." Adolescence 8 (Fa11 1973): 373-377.

Sobanska, J. "Relationships between Adolescents and their Parents." Psychologia Wychowancza 22 (August 1965): 225-245.

Strauss, G. H. "The Relationship of Family Concept to Variables of School Adfustment in Grades 4, 5, and 6." Ed. D. dissertation, Northern Illinois University, 1970.

Stryker, S. "Symbolic Interaction as an Approach to Family Research." Marriage and Family Living 21 (May 1959): 111-119.

- "The Interactional and Situational Approaches." In Handbook of Marriage and the Family, pp. 125-170. Edited by H. T. Christensen. Chlcago: Rand McNally and Company, 1964. 
van der Veen, F. "The Family Concept Q-Sort: A Brief Review of Findings and Studies in Progress." Chicago: Institute of Juvenile Research, 1966. (Mimeographed.)

- Family Concept Inventory. Chicago: Institute of Juvenile Research, 1969. (Mimeographed.)

- "Dimensions of the Family Concept and their Relation to Gender, Generation, and Disturbance." Proceedings of the 79 th Annual Meeting of the American Psychological Association, Washington, D. C., 1971 .

- "Family Interaction and Congrience of Family Concepts among Adolescents and their Parents." Paper presented at the Annual Conference of the National Council on Family Relations, St. Louis, 1974.

-; Haberlands, H. W. "Family Satisfaction and the Congruence of Family Concepts among Adolescents and their Parents." Proceedings of the 79th Annual Convention of the American Psychological Association, Washington, D. C., 1971.

.; Howard, K. I.; and Austria, A. M. "Stability and Equivalence of Scores Based on Three Different Response Formats." Reprinted from the Proceedings of the 78th Annual Convention of the American Psychological Association, 1970.

.; and Novak, A. L. "Family Concepts and Emotional Disturbance in Families of Disturbed Adolescents with Normal Siblings." Family Process 9 (June 1970): 157-171.

- "Perceived Parental Attitudes and Family Concepts of Disturbed Adolescents, Normal Siblings, and Normal Controls." Family Process 10 (September 1971): 327-343.

van der Veen, F.; Ostrander, K.; and van der Veen, M. "Some Results of the First Study of Clinic Families Using the Family Concept Q-Sort." Madison, Wisconsin: Dane County Mental Health Center, 1961. (Mimeographed.)

van der Veen, M., and Ostrander, K. "Developmental and Initial Uses of a Family Concept Q-Sort with Clinicians and Clients of the Dane County Guidance Center." M. A. thesis, University of Wisconsin, 1961.

Vogel, W.; and Lauterback, C. C. "Relationships Between Normal and Disturbed Sons' Percepts of their Parents' Behavior, and Personality Attributes of the Parents and Sons." Journal of Clinical Psychology 19 (January 1963): 52-56. 
Warimer, C. K. The Emergence of Society. Homewood, Illinois: Dorsey Press, 1970 .

Wheeler, D. K. "Adolescent Views of Parents in Western Australia." International Review of Education 67 (1960): 248-255.

Winch, R. F. Identification and its Familial Determinants. Indianapolis: Bobbs-Merrill Company, Inc., 1962. - The Modern Family. New York: Holt, Rinehart and Winstor, Inc., 1971.

Zimmerman, C. C. "The Future of the Family in America." Journal of Marrlage and the Family 34 (May 1972): 323-333. 
VITA

\section{Name: Lily Wong Hok-Neo}

Permanent Address: 6 Jalan Kebon Teh, Johor Baru, Johor, MALAYSIA

Degree and date to be conferred: Ed. D., 1976

Date of birth: March 9, 1944

Place of birth: Johor, MALAYSIA

Educational Background

Secondary diploma: Sultan Ibrahim Girls' School, Johor Baru, Johor, Malaysia

Undergraduate diploma: Philippine Union College, Manila, Ph1lippines B. S, E. Ed, , 1966

Graduate School: Philippine Union College, Manila, Philippines M. A., 1971 (Major: Elementary Education)

Andrews Unfversity, Berrien Springs, Michigan Ed. D., 1976 (Major: Educational psychology)

\section{Positions Held}

1974-76 Graduate Assistant, Andrews University, Berrien Springs, Michigan 49104

1971-74 Instructor and Assistant Professor, Southeast Asia Union College, Singapore

1970-71 Teacher, Seventh-day Advent1st Secondary School, Singapore.

1966-69 Teacher, Sunny Bill School, Kuching, Sarawak, Malaysia

Producer, Children's Corner, Radto Sarawak, Kuching, Sarawak, Malaysia

1963-64 Teacher, Seventh-day Adventist School (Elementary), Singapore 